\title{
Rosiglitazone for type 2 diabetes mellitus (Review)
}

\author{
Richter B, Bandeira-Echtler E, Bergerhoff K, Clar C, Ebrahim SH
}

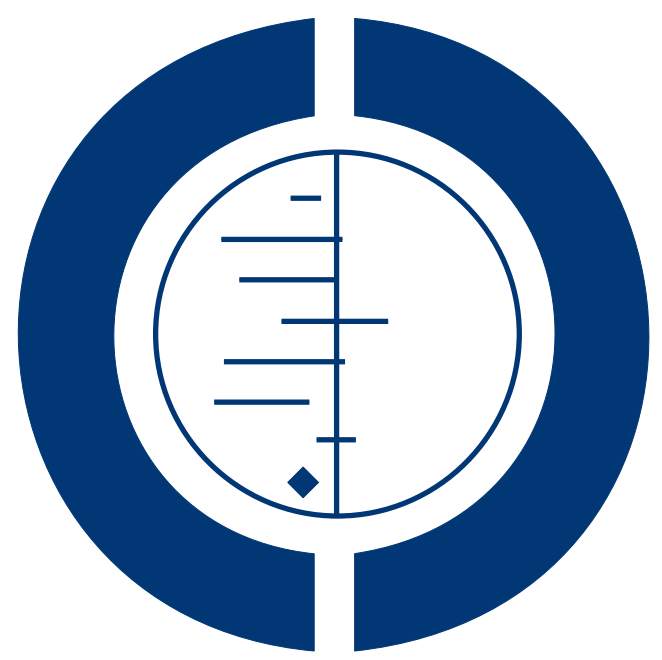

THE COCHRANE COLLABORATION $^{\circledR}$

This is a reprint of a Cochrane review, prepared and maintained by The Cochrane Collaboration and published in The Cochrane Library 2007, Issue 3

http://www.thecochranelibrary.com

\section{WILEY}


TABLE OF CONTENTS

HEADER . . . . . . . . . . . . . . . . . . . . . . . . . . . . . . . . . . 1

ABSTRACT . . . . . . . . . . . . . . . . . . . . . . . . . . . . . . . . . . . . . . . . . . . . . . .

PLAIN LANGUAGE SUMMARY . . . . . . . . . . . . . . . . . . . . . . . . . . . . . . . . . . . 2

BACKGROUND . . . . . . . . . . . . . . . . . . . . . . . . . . . . . . . . . . . . . . . . .

OBJECTIVES . . . . . . . . . . . . . . . . . . . . . . . . . . . . . . . . . . . . . . . . . . .

METHODS . . . . . . . . . . . . . . . . . . . . . . . . . . . . . . . . . . . . . .

RESULTS . . . . . . . . . . . . . . . . . . . . . . . . . . . . . . . . . . . . . . . 8

Figure 1. . . . . . . . . . . . . . . . . . . . . . . . . . . . . . . . . . . . 9

DISCUSSION . . . . . . . . . . . . . . . . . . . . . . . . . . . . . . . . . . . . .

AUTHORS' CONCLUSIONS . . . . . . . . . . . . . . . . . . . . . . . . . . . . . . . . . . . . . .

ACKNOWLEDGEMENTS . . . . . . . . . . . . . . . . . . . . . . . . . . . . . . . . . . 15

REFERENCES . . . . . . . . . . . . . . . . . . . . . . . . . . . . . . . . . . . . . . . . . . . . 16

CHARACTERISTICS OF STUDIES . . . . . . . . . . . . . . . . . . . . . . . . . . . . . . . . . . . . . . .

DATA AND ANALYSES . . . . . . . . . . . . . . . . . . . . . . . . . . . . . . . . . . . 54

Analysis 1.1. Comparison 1 Adverse events, Outcome 1 No. of patients experiencing oedema. . . . . . . . . . 54

APPENDICES . . . . . . . . . . . . . . . . . . . . . . . . . . . . . . . . . 54

FEEDBACK . . . . . . . . . . . . . . . . . . . . . . . . . . . . . . . . . . . . . . 96

WHAT'S NEW . . . . . . . . . . . . . . . . . . . . . . . . . . . . . . . . . . . . . . . . . . . . . 99

HISTORY . . . . . . . . . . . . . . . . . . . . . . . . . . . . . . . . . . . . . . . . . . 99

CONTRIBUTIONS OF AUTHORS . . . . . . . . . . . . . . . . . . . . . . . . . . . . . . . . . . . . . . . . . . . . .

DECLARATIONS OF INTEREST . . . . . . . . . . . . . . . . . . . . . . . . . . . . . . . 100

SOURCES OF SUPPORT . . . . . . . . . . . . . . . . . . . . . . . . . . . . . . . . . . . . . 100

DIFFERENCES BETWEEN PROTOCOL AND REVIEW . . . . . . . . . . . . . . . . . . . . . . 100

INDEX TERMS . . . . . . . . . . . . . . . . . . . . . . . . . . . . . . . . . . . 100

Rosiglitazone for type 2 diabetes mellitus (Review)

Copyright $\odot 2009$ The Cochrane Collaboration. Published by John Wiley \& Sons, Ltd. 


\title{
[Intervention Review]
}

\section{Rosiglitazone for type $\mathbf{2}$ diabetes mellitus}

\author{
Bernd Richter ${ }^{1}$, Elizabeth Bandeira-Echtler ${ }^{1}$, Karla Bergerhoff ${ }^{1}$, Christine Clar $^{2}$, Susanne H Ebrahim ${ }^{3}$ \\ ${ }^{1}$ Department of General Practice, Universitaetsklinikum Duesseldorf, Heinrich-Heine University, Duesseldorf, Germany. ${ }^{2}$ Researcher \\ in Systematic Reviews , Cochrane Metabolic and Endocrine Disorders Group, Berlin, Germany. ${ }^{3}$ Institute for Quality and Efficiency \\ in Health Care, Cologne, Germany \\ Contact address: Bernd Richter, Department of General Practice, Universitaetsklinikum Duesseldorf, Heinrich-Heine University, PO \\ Box 101007, Duesseldorf, 40001, Germany. richterb@uni-duesseldorf.de.
}

Editorial group: Cochrane Metabolic and Endocrine Disorders Group.

Publication status and date: Edited (no change to conclusions), published in Issue 1, 2009.

Review content assessed as up-to-date: 29 April 2007.

Citation: Richter B, Bandeira-Echtler E, Bergerhoff K, Clar C, Ebrahim SH. Rosiglitazone for type 2 diabetes mellitus. Cochrane Database of Systematic Reviews 2007, Issue 3. Art. No.: CD006063. DOI: 10.1002/14651858.CD006063.pub2.

Copyright (C) 2009 The Cochrane Collaboration. Published by John Wiley \& Sons, Ltd.

\begin{abstract}
A B S T R A C T
Background

Diabetes has long been recognised as a strong, independent risk factor for cardiovascular disease, a problem which accounts for approximately $70 \%$ of all mortality in people with diabetes. Prospective studies show that compared to their non-diabetic counterparts, the relative risk of cardiovascular mortality for men with diabetes is two to three and for women with diabetes is three to four. The two biggest trials in type 2 diabetes, the United Kingdom Prospective Diabetes Study (UKPDS) and the University Group Diabetes Program (UGDP) study did not reveal a reduction of cardiovascular endpoints through improved metabolic control. Theoretical benefits of the peroxisome proliferator activated receptor gamma (PPAR-gamma) activator rosiglitazone on endothelial function and cardiovascular risk factors might result in fewer macrovascular disease events in people with type 2 diabetes mellitus.
\end{abstract}

\section{Objectives}

To assess the effects of rosiglitazone in the treatment of type 2 diabetes.

\section{Search methods}

Studies were obtained from computerised searches of MEDLINE, EMBASE and The Cochrane Library.

\section{Selection criteria}

Studies were included if they were randomised controlled trials in adult people with type 2 diabetes mellitus and had a trial duration of at least 24 weeks.

\section{Data collection and analysis}

Two authors independently assessed trial quality and extracted data. Pooling of studies by means of fixed-effects meta-analysis could be performed for adverse events only.

\section{Main results}

Eighteen trials which randomised 3888 people to rosiglitazone treatment were identified. Longest duration of therapy was four years with a median of 26 weeks. Published studies of at least 24 weeks rosiglitazone treatment in people with type 2 diabetes mellitus did not provide evidence that patient-oriented outcomes like mortality, morbidity, adverse effects, costs and health-related quality of life are positively influenced by this compound. Metabolic control measured by glycosylated haemoglobin A1c (HbA1c) as a surrogate

Rosiglitazone for type 2 diabetes mellitus (Review)

Copyright $\odot 2009$ The Cochrane Collaboration. Published by John Wiley \& Sons, Ltd. 
endpoint did not demonstrate clinically relevant differences to other oral antidiabetic drugs. Occurrence of oedema was significantly raised (OR 2.27, 95\% confidence interval (CI) 1.83 to 2.81). The single large RCT (ADOPT - A Diabetes Outcomes Progression Trial) indicated increased cardiovascular risk. New data on raised fracture rates in women reveal extensive action of rosiglitazone in various body tissues.

\section{Authors' conclusions}

New studies should focus on patient-oriented outcomes to clarify the benefit-risk ratio of rosiglitazone therapy. Safety data and adverse events of all investigations (published and unpublished) should be made available to the public.

\section{PLAIN LANGUAGE SUMMARY}

\section{Rosiglitazone for type 2 diabetes mellitus}

Diseases of the heart and blood vessels account for approximately $70 \%$ of all mortality in people with diabetes. Compared to their non-diabetic counterparts the relative risk of mortality caused by disorders of the heart and blood vessels is two to three for men and three to four for women with diabetes. Type 2 diabetes is mainly characterised by a reduced ability of the hormone insulin to stimulate glucose uptake in body fat and muscles (insulin resistance) and affects most people suffering from diabetes. Several medications are on the market to treat diabetes, amongst them rosiglitazone as a member of the 'glitazones' reduced risk markers for diseases of the heart and blood vessels. Since the two biggest trials in people with type 2 diabetes showed that improved blood glucose alone is not enough to reduce the risk of the above mentioned diseases we looked for longer-term studies investigating 24 weeks as a minimum of rosiglitazone treatment on patient-oriented outcomes. As patient-oriented outcomes we defined mortality, complications of diabetes, side effects of the medication, health-related quality of life, costs and metabolic control (lowering of blood glucose to near normal levels).

Eighteen trials randomised 3888 people to rosiglitazone therapy. The longest duration of rosiglitazone treatment was four years, most trials lasted around half a year. Unfortunately, the published studies of at least 24 weeks rosiglitazone treatment in people with type 2 diabetes mellitus did not provide relevant evidence that patient-oriented outcomes are positively influenced by this agent. The chance of developing oedema was approximately doubled, the risk of cardiovascular diseases increased. The single large randomised controlled trial showed evidence of raised cardiovascular risk after rosiglitazone treatment. Moreover, new safety data show increased numbers of broken bones in women. This finding was published years after approval of this agent by drug regulatory authorities. New ways of exploring drug effects, for example by early long-term studies in many people, as well as public access to all safety data of published and unpublished investigations have to be established.

\section{B A C K G R O U N D}

\section{Description of the condition}

Diabetes mellitus is a metabolic disorder resulting from a defect in insulin secretion, insulin action, or both. A consequence of this is chronic hyperglycaemia (that is elevated levels of plasma glucose) with disturbances of carbohydrate, fat and protein metabolism. Long-term complications of diabetes mellitus include retinopathy, nephropathy and neuropathy. The risk of cardiovascular disease is increased. For a detailed overview of diabetes mellitus, please see under 'Additional information' in the information on the Metabolic and Endocrine Disorders Group in The Cochrane
Library (see 'About', 'Cochrane Review Group (CRGs)'). For an explanation of methodological terms, see the main glossary in The Cochrane Library.

There are two main types of diabetes mellitus, type 1 (formerly termed insulin-dependent diabetes mellitus) and type 2 (formerly termed non-insulin dependent diabetes mellitus):

\section{Type I diabetes mellitus}

Type 1 diabetes is a chronic disease characterised by hyperglycaemia due to absolute deficiency of insulin secretion which is caused by autoimmune destruction of the pancreatic beta cells. Evidence of autoimmunity is provided by the appearance of autoantibodies prior to the onset of clinical disease. The clinical pre- 
sentation ranges from mild nonspecific symptoms or no symptoms to coma. Although type 1 diabetes usually develops before 30 years of age, it can occur at any age. At presentation, most patients are thin and have experienced weight loss, polyuria, polydipsia, fatigue, and diabetic ketoacidosis.

\section{Type 2 diabetes mellitus}

In type 2 diabetes mellitus, the actions and secretion of insulin are impaired, as opposed to the absolute deficiency of insulin that occurs with type 1 diabetes mellitus. Type 2 diabetes is characterised by two major pathophysiologic defects: (1) insulin resistance, which results in increased hepatic glucose production and decreased peripheral glucose disposal, (2) impaired $\beta$-cell secretory function (Kahn 1997). Insulin resistance is an impaired biological response to the effects of exogenous or endogenous insulin. Insulin resistance in the hepatic and peripheral tissues, particularly skeletal muscle, leads to unrestrained hepatic glucose production and diminished insulin-stimulated peripheral glucose uptake and utilization (DeFronzo 1992). Insulin secretion by the pancreatic beta cell is initially sufficient to compensate for insulin resistance, thereby maintaining normal blood glucose levels. Hyperinsulinaemia, which accompanies insulin resistance, can maintain sufficiently normal glucose metabolism as long as pancreatic $\beta$-cell function remains normal. However, in patients who may develop type 2 diabetes, insulin secretion eventually fails, leading to hyperglycaemia and clinical diabetes (Warram 1990). Individuals with type 2 diabetes may have few or no classic clinical symptoms (see above) of hyperglycaemia (Ruige 1997). The difficulty in maintaining metabolic control, for example measured by haemoglobin $\mathrm{A}_{1 c}\left(\mathrm{HbA}_{1 c}\right)$ over time may be related to several behavioral factors (for example difficulties with healthy eating, exercise, medication regimens) but primarily reflects the underlying progressive decline in $\beta$-cell function (UKPDS-16 1995).

Type 2 diabetes has traditionally been treated in a stepwise manner, starting with lifestyle modifications (Armour 2004; Gimenez-Perez 2001; Moore 2005), exercise (Thomas 2001) and later on pharmacotherapy with oral agents. Several classes of oral agents are available for clinical use. These mainly include insulin secretagogues, drugs that delay the absorption of carbohydrates from the gastrointestinal tract, and insulin sensitizers. Over time, many patients with type 2 diabetes will require insulin therapy (Burt 2005; Misso 2005; Richter 2005; Roberts 2005; Royle 2003; Siebenhofer 2004).

Insulin secretagogues: Currently, the sulphonylureas used are mainly glibenclamide (glyburide), glipizide, chlorpropamide, tolbutamide, and glimepiride. These drugs stimulate pancreatic $\beta$-cell insulin secretion by binding to a sulphonylurea receptor (Lindberg 2002). The short-acting non-sulphonylurea insulin secretagogues are repaglinide and nateglinide (Black 2003). These are newer agents that also stimulate insulin secretion by binding to the sulphonylurea receptor.
Alpha-glucosidase inhibitors: Acarbose and miglitol are $\alpha$-glucosidase inhibitors. These drugs slow the absorption of carbohydrates, reducing especially postprandial elevations in plasma glucose levels. They do not significantly lower fasting plasma glucose levels but cause a modest reduction in $\mathrm{HbA}_{1 c}$ (Van de Laar 2005).

Insulin sensitizers: Metformin belongs to the biguanides class (Saenz 2005; Salpeter 2003). It might increase insulin sensitivity in the liver by inhibiting hepatic gluconeogenesis and thereby reducing hepatic glucose production. Metformin also seems to increase peripheral insulin sensitivity by enhancing glucose uptake in the muscle. The thiazolidinediones consist of rosiglitazone and pioglitazone. These substances decrease insulin resistance in muscle and adipose tissue by activating the peroxisome proliferator-activated receptor $\gamma(\mathrm{PPAR}-\gamma)$ which increases production of proteins involved in glucose uptake. They also decrease hepatic glucose production by improving hepatic insulin sensitivity (Meriden 2004).

\section{Description of the intervention}

Type 2 diabetes mellitus can be treated by non-pharmacological (diet, exercise) and pharmacological means. Insulin, as the natural hormone of the body, might be given as animal (mainly pork or beef) insulin (Richter 2005), genetically constructed 'human' insulin or as insulin-'analogues' with a modified molecular structure compared to human insulin (Roberts 2005; Siebenhofer 2004). Insulin is currently administered by diabetic people in various ways: Subcutaneous injections, insulin pumps (Misso 2005), and maybe in future by inhalation (Burt 2005; Royle 2003). Oral antidiabetic agents are most often used to treat type 2 diabetes mellitus in its initial stages if lifestyle modifications have failed. The thiazolidinediones rosiglitazone and pioglitazone offer new oral treatment options and affect many tissues and parts of the body. In order to evaluate their effects not only on metabolic control in type 2 diabetes mellitus but also on patient-oriented outcomes like cardiovascular disease, longer-term studies of at least 24 weeks continuous intake will be critically appraised in this review.

\section{Adverse effects of the intervention}

An increase in bodyweight has been associated with rosiglitazone. Oedema, anaemia and congestive heart failure have been reported in patients receiving rosiglitazone. The patients who appear to be at greatest risk of peripheral oedema, fluid retention and weight gain, congestive heart failure and pulmonary oedema related to rosiglitazone are probably those who use insulin or have New York Heart Association class II, III or IV cardiac status, left-ventricular dysfunction or renal insufficiency. Some reports of visual impairment in patients taking rosiglitazone were described (Colucciello 2005). Case reports of liver function abnormalities associated with rosiglitazone were documented (Marcy 2004; Menees 2005; Su 2006). 


\section{How the intervention might work}

Because traditional agents have a limited impact on insulin resistance and $\beta$-cell function, thiazolidinediones may be an appropriate choice especially for combination therapy in patients achieving poor glycaemic control with initial monotherapy. By improving insulin sensitivity, thiazolidinediones may exert beneficial effects on cardiovascular risk factors. The excess cardiovascular risk in type 2 diabetes cannot be attributed to classic risk factors alone (mainly hypertension, hypercholesterolaemia and smoking), but if present, these risk factors are at least as important as in patients without diabetes (Stamler 1993). One explanation for the beneficial effects of thiazolidinediones is their unique mechanism of action as selective and potent inhibitors of PPAR- $\gamma$. PPAR $-\gamma$ receptors are present in many tissues like adipose, hepatic and skeletal muscle tissue and control insulin-responsive genes, which have a wide-ranging influence. Thiazolidinediones appear to improve markers of inflammation and fibrinolysis, exert beneficial effects on vascular reactivity, improve the lipid profile and fat distribution, and decrease pancreatic $\beta$-cell injury.

Rosiglitazone is a member of the thiazolidinedione group which also encompasses troglitazone (withdrawn due to hepatic toxicity) and pioglitazone. It increases the sensitivity of skeletal muscle, liver and adipose tissue to insulin without directly stimulating insulin secretion from pancreatic $ß$-cells, thereby reducing plasma glucose levels and endogenous glucose production (Wagstaff 2002). Differences in the side chain on the main thiazolidine-structure in comparison to pioglitazone are thought to be responsible for the distinct bioavailability, metabolism and antihyperglycaemic potency of rosiglitazone. Although rosiglitazone appears to be associated with some effects that are not mediated by PPAR- $\gamma$ (Yang 2001), binding of rosiglitazone to this receptor seems to be the important component of its mechanism of action. Rosiglitazone has several pharmacodynamic properties which could ameliorate the increased risk of cardiovascular disease in type 2 diabetes mellitus. In clinical studies in patients with type 2 diabetes mellitus, rosiglitazone has been associated with reductions in the levels of small dense low density lipoprotein-cholesterol (LDL-C) - despite overall increases in total LDL-C - and increases in the levels of high density lipoprotein-cholesterol (HDL-C). Diastolic and systolic blood pressure are thought to be decreased after rosiglitazone treatment. Some other surrogate parameters indicating especially cardiovascular risk were reported to be positively influenced by rosiglitazone therapy.

\section{Why it is important to do this review}

Diabetes has long been recognised as a strong, independent risk factor for cardiovascular disease, a problem which accounts for approximately $70 \%$ of all mortality in people with diabetes (Laakso 1999). Prospective studies show that compared to their non-diabetic counterparts, the relative risk of cardiovascular mortality for men with diabetes is two to three and for women with diabetes is three to four (Manson 1991; Stamler 1993). The increased cardiovascular risk associated with diabetes is reflected in the observation that middle-aged individuals with diabetes have mortality and morbidity risks that are similar to non-diabetic individuals who have already suffered a cardiovascular event (Haffner 1998). Both epidemiological and prospective data have demonstrated that treatment of hyperglycaemia in type 2 diabetes mellitus is effective in reducing the risk of microvascular disease (for example diabetic retinopathy) but is less potent in reducing that of myocardial infarction, stroke and peripheral vascular disease. Treatment of other cardiovascular risk factors, although by definition less prevalent than hyperglycaemia, appears to be more effective in preventing macrovascular disease than treatment of hyperglycaemia. The University Group Diabetes Program (UGDP) study was the first published long-term investigation of people with type 2 diabetes indicating no reduction of cardiovascular endpoints through improved metabolic control but raised cardiovascular mortality after tolbutamide treatment (UGDP 1982). The study of Ohkubo et al. which included relatively lean Japanese patients with type 2 diabetes, was the first to demonstrate prevention of microvascular complications by intensive glucose control in patients with type 2 diabetes (Ohkubo 1995). This study did not address the question of whether good glycaemic control retards the progression of macrovascular disease. The United Kingdom Prospective Diabetes Study (UKPDS) tested mainly whether intensive glucose control with either a sulphonylurea or insulin influences the risk of micro- and macrovascular complications compared with conventional treatment (UKPDS-33 1998). The 10-year results of the UKPDS evaluated drug treatment in non obese and obese participants with newly diagnosed type 2 diabetes who were referred to hospital clinics. Over 10 years, $\mathrm{HbA}_{1 c}$ was $7.0 \%$ in the intensive group compared with $7.9 \%$ in the conventional group. The $0.9 \%$ difference in $\mathrm{HbA}_{1 c}$ between the intensive and conventional groups over 10 years was smaller than the $1.9 \%$ difference (9.0\% and 7.1\%) in $\mathrm{HbA}_{1 c}$ in the Diabetes Control and Complications Trial (DCCT). The DCCT studied younger patients with type 1 diabetes and assessed the effects of intensive versus conventional insulin therapy on the incidence of microvascular complications of diabetes (retinopathy, nephropathy, neuropathy) over a mean follow-up of 6.5 years (DCCT 1993). The risk of retinopathy, for example, was statistically significant reduced by intensive insulin therapy with a number needed to treat (NNT) to benefit of six (six type 1 diabetic patients need to be treated by intensive in comparison to conventional insulin therapy over 6.5 years to avoid one additional patient to develop diabetic retinopathy). The UKPDS had a factorial design meaning that another study investigating intensive versus regular blood pressure control (HDS 1993; UKPDS-38 1998) was imbedded in the main study. Intensive versus conventional glucose control did not result in a statistically significant difference in diabetes related mortality or macrovascular disease endpoints but reduced the relative risk in

Rosiglitazone for type 2 diabetes mellitus (Review) 
the 'any diabetes related aggregate endpoint' (Freemantle 2003). Most of this benefit was due to a reduction in microvascular endpoints including the incidence of retinal photocoagulation, which was assessed by ophthalmologists independent of the study. In the UKPDS, the NNT to prevent one patient developing any of the single endpoints over 10 years was 20 (95\% confidence interval (CI) 10 to 500) patients (UKPDS-33 1998). In contrast to these results, publication of the UKPDS-34, which focused on obese patients with newly diagnosed type 2 diabetes, found several clinically important differences in macrovascular disease endpoints with 10 years of treatment with metformin (UKPDS-34 1998). In particular, the absolute risk reduction for the aggregate endpoints was more than $10 \%$ and for overall mortality was $7 \%$, giving NNTs of 10 and 14, respectively, over 10 years (McCormack 2003).

The UKPDS was criticised on several grounds especially emphasising hidden biases in interpreting the results of this randomised controlled trial (Ewart 2001; McCormack 2003; Nathan 1998). Stratton et al. in their UKPDS-35 publication are often cited, who tried to determine the relation between exposure to glycaemia over time and the risk of macrovascular or microvascular complications in the UKPDS patients (Stratton 2000). This publication is an epidemiological re-interpretation of UKPDS data proclaiming that with each $1 \%$ reduction in mean $\mathrm{HbA}_{1 c}$, reductions in risk of $21 \%$ for deaths related to diabetes and $14 \%$ for myocardial infarction could be observed. The RCT itself, though, did not show significant differences in this respect. Moreover, the UKPDS-38, investigating tight versus less tight blood pressure control with the use of an angiotensin converting enzyme inhibitor captopril or a $\beta$-blocker atenolol as main treatment, showed relative risk reductions (in the group assigned to tight control compared with that assigned to less tight control) of $24 \%$ in diabetes related endpoints, $32 \%$ in deaths related to diabetes, $44 \%$ in strokes and $37 \%$ in microvascular endpoints (UKPDS-38 1998). Due to the factorial design of the UKPDS with two interventions (improvement in metabolic and blood pressure control) aiming at the same outcomes, a fair interpretation of the data needs investigation of the interaction between the two main treatment strategies (McAlister 2003; Montgomery 2003). UKPDS data should be available to the scientific public to evaluate, among other things, the importance of the individual contribution of improved glucose versus blood pressure control in type 2 diabetes mellitus. Unfortunately, until now this has not happened.

Therefore, any new compound in the treatment of type 2 diabetes mellitus, like rosiglitazone, should not only be evaluated with regards to surrogate outcomes (for example reductions in fasting plasma glucose or $\mathrm{HbA}_{1 c}$ ) but information is urgently needed for the influence of any antidiabetic agent especially on cardiovascular endpoints, which is the greatest problem in the therapy of type 2 diabetes mellitus. Quite a number of health technology assessment reports, (narrative) reviews, systematic reviews and meta-analyses analysed interventions with rosiglitazone in diabetes (Bloomgarden 2005; Boucher 2002; Boucher 2003; Chiquette 2004; Cox 2004; Czoski-Murray 2004; Kreider 2002; Lebovitz 2002; Malinowski 2000; Mukhtar 2005; NICE 2000; NICE 2003; NICE 2003b; Wagstaff 2002; Wellington 2005). All of them either suffer from methodological problems like insufficient quality assessment of primary studies, focus on surrogate outcomes or are out-of-date. This systematic review tries to collate all available data from RCTs of rosiglitazone treatment and evaluates how many studies investigated patient-oriented outcomes like mortality, cardiovascular endpoints, adverse events and health-related quality of life.

A Cochrane review on the effects of pioglitazone treatment has already been published (Richter 2006). For changes to the published protocol see Appendix 12.

As this review contributes to the ongoing critical appraisal of RCTs investigating the risk-benefit ratio of thiazolidinedione use by the German Institute for Quality and Efficiency in Health Care ('Institut fuer Qualitaet und Wirtschaftlichkeit im Gesundheitswesen - IQWiG), additional data (for example raw data from pharmaceutical companies often provided to IQWiG) of relevance might be included in further updates.

\section{O B J E C T I VES}

To assess the effects of rosiglitazone in the treatment of type 2 diabetes.

\section{METHODS}

\section{Criteria for considering studies for this review}

\section{Types of studies}

Randomised controlled trials.

\section{Types of participants}

Adult persons (18 years or older) with type 2 diabetes mellitus. To be consistent with changes in classification and diagnostic criteria of type 2 diabetes mellitus through the years, the diagnosis should have been established using the standard criteria valid at the time of the beginning of the trial (for example ADA 1997; ADA 1999; WHO 1980; WHO 1985; WHO 1998). Ideally, diagnostic criteria should have been described. If necessary, authors' definition of type 2 diabetes mellitus was used. It was planned to subject diagnostic criteria to a sensitivity analysis. 


\section{Types of interventions}

Therapy with rosiglitazone for a minimum of 24 weeks. The following comparisons were acceptable for evaluation:

- rosiglitazone versus placebo;

- rosiglitazone versus another oral antidiabetic medication (meglitinide analogues, metformin, pioglitazone,

sulphonylureas);

- rosiglitazone in combination with an oral antidiabetic medication or insulin versus a combination of an oral antidiabetic medication or insulin (agents and treatment schemes had to be identical).

\section{Excluded interventions}

Combination therapies consisting of different compounds in the treatment arms (for example rosiglitazone plus metformin versus uptitration of metformin or rosiglitazone plus gliclazide versus gliclazide). Another Cochrane review will investigate rosiglitazonemetformin combination therapies including different treatment regimens of these compounds. Furthermore, dipeptidyl peptidase4 (DPP-4) inhibitors for type 2 diabetes mellitus are excluded, since these are the topic of another Cochrane review (Richter 2007), as well as glucagon-like peptide analogues for type 2 diabetes mellitus (Cochrane review, Snaith 2007).

\section{Types of outcome measures}

\section{Primary outcomes}

- mortality (all-cause mortality; diabetes related mortality (death from myocardial infarction, stroke, peripheral vascular disease, renal disease, hyper- or hypoglycaemia or sudden death));

- morbidity (all-cause morbidity as well as diabetes and cardiovascular related morbidity, for example angina pectoris, myocardial infarction, stroke, peripheral vascular disease, neuropathy, retinopathy, nephropathy, erectile dysfunction, amputation);

- adverse events (for example hypoglycaemia, congestive heart failure, oedema).

\section{Secondary outcomes}

- health-related quality of life (using a validated instrument);

- costs;

- metabolic control as measured by glycosylated haemoglobin A1c (HbA1c).

\footnotetext{
Covariates, effect modifiers and confounders

- compliance;

- co-morbidities (for example myocardial infarction, stroke);
}

- co-medication (for example antihypertensive drugs, aspirin);

- age.

\section{Timing of outcome measurement}

Outcomes were assessed in the medium (24 weeks to less than 12 months of treatment) and long term (12 months or more of treatment).

\section{Search methods for identification of studies}

\section{Electronic searches}

We used the following sources for the identification of trials:

- The Cochrane Library (issue 1, 2007);

- MEDLINE - OVID interface (until April 2007);

- EMBASE - OVID interface (until April 2007).

We also searched databases of ongoing trials: Current Controlled Trials (www.controlled-trials.com - with links to other databases of ongoing trials).

The described search strategy (see for a detailed search strategy Appendix 1) was used for MEDLINE. For use with EMBASE and The Cochrane Library this strategy was slightly adapted.

Additional key words of relevance were not identified during any of the electronic or other searches. If this had been the case, electronic search strategies would have been modified to incorporate these terms. Studies published in any language were included.

\section{Searching other resources}

We tried to identify additional studies by searching the reference lists of included trials and (systematic) reviews, meta-analyses and health technology assessment reports identified.

\section{Data collection and analysis}

\section{Selection of studies}

To determine the studies to be assessed further, two authors (BR in combination with all the other authors) independently scanned the abstract or titles, or both sections of every record retrieved. All potentially relevant articles were investigated as full text. Interrater agreement for study selection was measured using the kappa statistic (Cohen 1960). Where differences in opinion existed, they were resolved by a third party (other authors). If resolving disagreement was not possible, the article would have been added to those 'awaiting assessment' and authors would have been contacted for clarification. An adapted QUOROM (quality of reporting of metaanalyses) flow-chart of study selection is attached (Moher 1999). 


\section{Dealing with duplicate publications}

In the case of duplicate publications and companion papers of a primary study, we tried to maximise yield of information by simultaneous evaluation of all available data. In cases of doubt, the original publication (usually but not always the oldest version) obtained priority.

\section{Data extraction and management}

For studies that fulfilled inclusion criteria, two authors (BR in combination with all the other authors) independently abstracted relevant population and intervention characteristics using standard data extraction templates (for details see Characteristics of included studies and Appendix 2 to Appendix 16) with any disagreements to be resolved by discussion, or if required by a third reviewer. The data extraction form was pilot tested prior to use and modified. Any relevant missing information on the trial would have been sought from the original author(s) of the article, if required.

\section{Assessment of risk of bias in included studies}

Two authors (BR in combination with all the other authors) assessed each trial independently. Possible disagreement was resolved by consensus, or with consultation of a third reviewer in case of disagreement. We planned to explore the influence of individual quality criteria in a sensitivity analysis (see under 'sensitivity analyses'). Interrater agreement for key quality indicators (concealment of allocation, blinding, attrition rates) was planned to be calculated using the kappa statistic (Cohen 1960). In cases of disagreement, the rest of the group was consulted and a judgement was made based on consensus.

\section{Measures of treatment effect}

\section{Dichotomous data}

Dichotomous outcomes (for example stroke yes/no) were planned to be expressed as odds ratios (OR) or relative risks (RR) with $95 \%$ confidence intervals (CI).

\section{Continuous data}

Continuous outcomes (for example metabolic control as measured by glycosylated haemoglobin A1c (HbA1c) were planned to be expressed, if possible, as mean differences with $95 \%$ CI.

\section{Time-to-event data}

Time-to-event outcomes (for example time until death) were planned to be expressed as hazard ratios (HR) with 95\% CI.

\section{Unit of analysis issues}

Different units of analysis (for example OR and RR) were planned to be subjected to a sensitivity analysis.

\section{Dealing with missing data}

Relevant missing data were planned to be obtained from authors. Evaluation of important numerical data such as screened, eligible and randomised patients as well as intention-to-treat and perprotocol population was carefully performed. Drop-outs, misses to follow-up and withdrawn study participants were investigated. Issues of last-observation-carried-forward (LOCF) were critically appraised and compared to specification of primary outcome parameters and power calculation.

\section{Assessment of heterogeneity}

In the event of substantial clinical or methodological or statistical heterogeneity, study results were not planned to be combined in a meta-analysis. Heterogeneity was identified by visual inspection of the forest plots, by using a standard $\chi^{2}$-test and a significance level of $\alpha=0.1$, in view of the low power of such tests. Quantification of heterogeneity was also examined with $\mathrm{I}^{2}$, ranging from $0 \%$ to $100 \%$ including its $95 \%$ confidence interval (Higgins 2002). $\mathrm{I}^{2}$ demonstrates the percentage of total variation across studies due to heterogeneity and was used to judge the consistency of evidence. $\mathrm{I}^{2}$ values of $50 \%$ and more indicate a substantial level of heterogeneity (Higgins 2003). When heterogeneity was found, we attempted to determine potential reasons for it by examining individual study characteristics and those of subgroups of the main body of evidence.

\section{Assessment of reporting biases}

Funnel plots were planned to be used in exploratory data analyses to assess for the potential existence of small study bias. There are a number of explanations for the asymmetry of a funnel plot, including true heterogeneity of effect with respect to study size, poor methodological design of small studies and publication bias (Sterne 2001). Thus, this exploratory data tool may be misleading (Lau 2006; Tang 2000; Thornton 2000) and we did not place undue emphasis on this tool.

\section{Data synthesis}

Data were planned to be summarised statistically if they were available, sufficiently similar and of sufficient quality. Statistical analysis was planned to be performed according to the statistical guidelines referenced in the newest version of the Cochrane Handbook for Systematic Reviews of Interventions (Higgins 2005). Pooled results were planned to be analysed using primarily a fixedeffect model. Meta-regression was planned to be performed using 
Stata/SE (version 8, Stata Corporation, Texas USA) to determine whether various study-level characteristics (for example follow-up interval, duration of the intervention, total attrition, year of publication) affected the between-group changes in primary outcomes. We planned to examine interaction terms for all models.

\section{Subgroup analysis and investigation of heterogeneity}

Subgroup analyses were planned to be performed only if one of the primary outcome parameters demonstrated statistically significant differences between treatment groups. The following subgroup analyses were planned:

- gender (female versus male);

- age (depending on data but especially older versus younger patients);

- patients with or without co-morbidities (for example heart attack, stroke, peripheral vascular disease);

- patients with or without co-medication (for example antihypertensive drugs, statins, aspirin).

Subgroup analyses were planned to be mainly used to explore clinical or methodological or statistical heterogeneity.

\section{Sensitivity analysis}

We planned to perform sensitivity analyses in order to explore the influence of the following factors on effect size:

- repeating the analysis excluding unpublished studies;

- repeating the analysis taking account of study quality, as specified above;
- repeating the analysis excluding any very long or large studies to establish how much they dominate the results;

- repeating the analysis excluding studies using the following filters: diagnostic criteria, language of publication, source of funding (industry versus other), country.

The robustness of the results was also planned to be tested by repeating the analysis using different measures of effects size (risk difference, odds ratio etc.) and different statistical models (fixed and random-effects models).

\section{R E S U L T S}

\section{Description of studies}

See: Characteristics of included studies; Characteristics of excluded studies; Characteristics of ongoing studies.

\section{Results of the search}

The initial search identified 6058 records with eight additional publications from reference lists; from these, 40 full papers were singled out for further examination. The other studies were excluded on the basis of their abstracts or titles because they were not relevant to the question under study (see Figure 1 for details of the amended QUOROM (quality of reporting of meta-analyses) statement). After screening the full text of the selected papers, 32 publications describing 18 studies finally met the inclusion criteria.

Rosiglitazone for type 2 diabetes mellitus (Review) 
Figure I. QUOROM (quality of reporting of meta-analyses) flow-chart of study selection

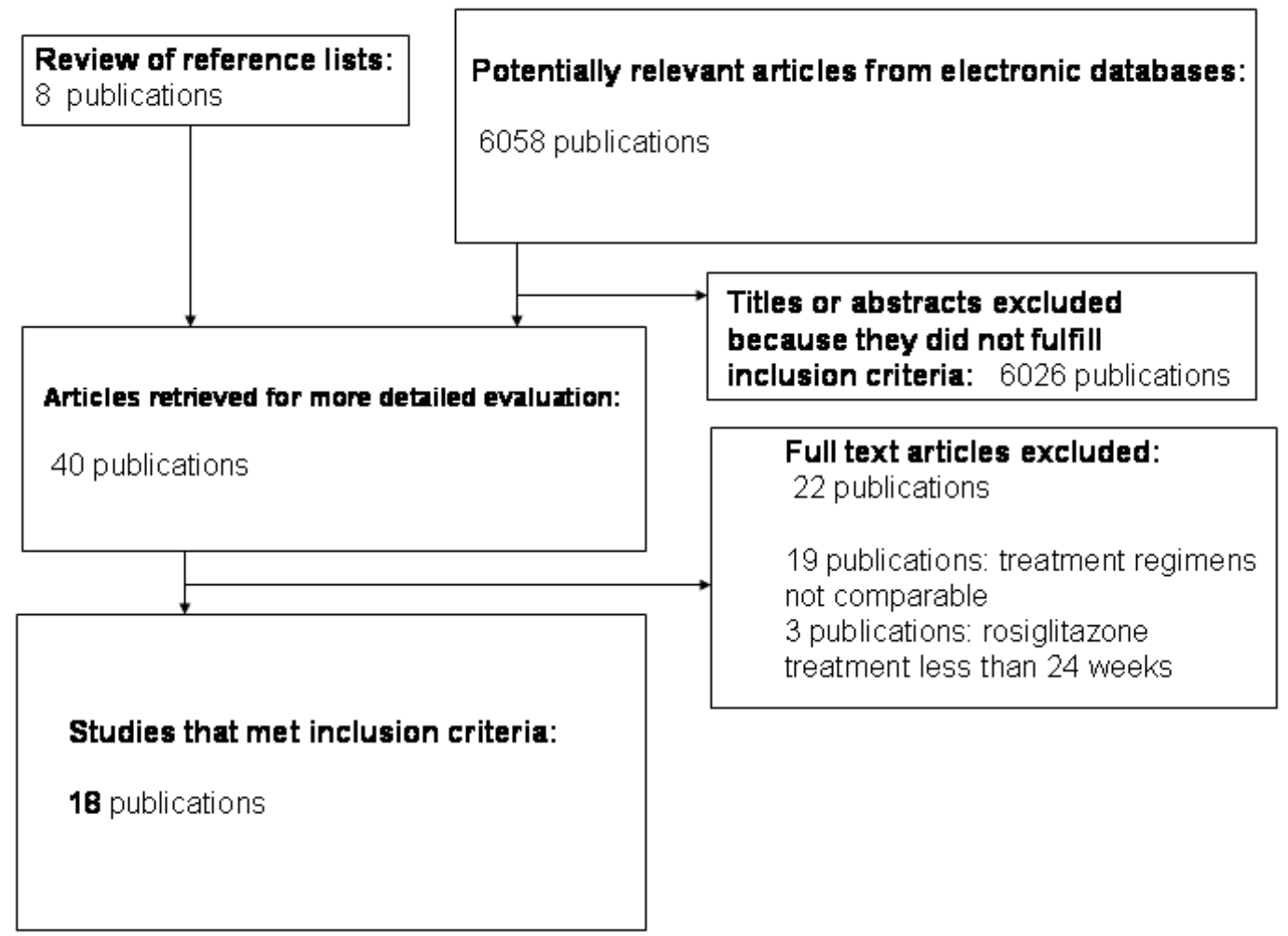

Most studies of at least 24 weeks rosiglitazone treatment were published in the years 2005 to 2007 (10 trials), with the first study was published in 2001 .

\section{Assessment of publication bias inter-rater agreement}

Inter-rater agreement for study selection, that is qualifying a study as 'included' or 'potentially relevant' was $95 \%$.

\section{Monotherapy}

- Five study arms compared rosiglitazone to placebo.

- Three study arms investigated rosiglitazone versus metformin, two versus glyburide and one each versus repaglinide or pioglitazone.

\section{Included studies}

For details see Characteristics of included studies.

\section{Interventions}

\section{Comparisons}

Ten of the 18 included publications investigated rosiglitazone monotherapy versus another monotherapy (12 monotherapy arms), eight publications evaluated the combination of rosiglitazone with another glucose-lowering intervention versus a comparable combination.

\section{Combination therapy}

- Eight publications investigated rosiglitazone combination therapy versus a similar combination with another compound.

- Two studies evaluated glimepiride and metformin combination, and one glibenclamide plus metformin, pioglitazone plus metformin or pioglitazone plus glimepiride, respectively.

- Three publications reported on triple combination comparisons (sulphonylurea or glimepiride plus metformin plus insulin). 


\section{Number of study centres}

Number of study centres ranged between one and 488, the multicentre design was dominant with a median of 31 study centres. Seven trials involved a substantial number of more than 40 study centres (Garber 2006; Goldberg 2005; Hanefeld 2007; Kahn 2006; Lebovitz 2001; Phillips 2001; Rosenstock 2006b ).

\section{Country and location}

Ten studies were performed in the USA and Canada, six in Europe, one in Latin America, and one in China, Korea an Taiwan, respectively (summarising to more than 18 studies due to multinational designs).

\section{Setting}

Eight publications presented some details about the study setting, like recruitment of participants.

\section{Treatment before study}

If stated, most studies specified that pharmacotherapy like sulphonylureas, metformin or both were used by participants before entering the study. In two studies participants were treated by diet, exercise or both, only (Hällsten 2002; Kahn 2006).

\section{Methods}

\section{Duration of the intervention}

Median treatment duration lasted 26 weeks, the longest trial had a median duration of four years (Kahn 2006).

\section{Duration of follow-up}

Treatment duration and follow-up were identical in all studies, no post-intervention follow-up was reported.

\section{Run-in period}

Ten studies described run-in periods. These usually lasted four weeks where previous antidiabetic medication was stopped, titration of new medication started or a placebo intervention initiated.

\section{Language of publication}

All included studies were published in English.

\section{Participants}

\section{Who participated}

Study participants were mainly white individuals with type 2 diabetes mellitus, in two studies the entire cohort was pharmaconaive (that is, people treated with diet only - Hällsten 2002; Kahn 2006).

\section{Inclusion criteria}

Investigators specified various inclusion criteria, such as diet nonresponders, sulphonylureas or metformin, or both failures and certain glycosylated haemoglobin A1c (HbA1c) levels.

\section{Exclusion criteria}

Investigators specified various exclusion criteria. Nine of 18 included studies stipulated specific exclusion criteria for the severity of congestive heart failure (NYHA (New York Heart Association) classification): Seven studies mentioned NYHA class III or IV and two studies NYHA I or above (including the biggest trial, the ADOPT (A Diabetes Outcomes Progression Trial) study - Kahn 2006).

\section{Diagnostic criteria}

Twelve studies provided some details of diagnostic criteria for type 2 diabetes mellitus.

\section{Co-morbidities}

Only four studies presented data on co-morbidities (Goldberg 2005; Jung 2005; Stocker 2007; Sutton 2002 ).

\section{Co-medications}

Six of the 18 included studies reported co-medications, either glucose-lowering drugs or medication for other disorders, or both (Derosa 2004; Derosa 2006b; Jung 2005; Kahn 2006; Ko 2006; Stocker 2007).

\section{Outcomes}

\section{Primary outcomes}

Most studies investigated HbAlc and lipid parameters (such as total cholesterol, high-density and low-density lipoprotein cholesterol, triglycerides) as primary endpoints. 


\section{Secondary and additional outcomes}

Most studies evaluated lipid parameters, fasting and non-fasting plasma glucose, adverse events, insulin, HbA1c, C-peptide and indicators for insulin resistance as secondary outcomes.

\section{Missing data}

For this version of the review no author was contacted for additional data. As this review contributes to the ongoing critical appraisal of RCTs investigating the risk-benefit ratio of thiazolidinedione use by the German Institute for Quality and Efficiency in Health Care ('Institut fuer Qualitaet und Wirtschaftlichkeit im Gesundheitswesen - IQWiG), additional data (for example raw data from pharmaceutical companies often provided to IQWiG) of relevance might be included in further updates.

\section{Excluded studies}

Twenty-two publications had to be excluded after careful evaluation of the full publication. Main reasons for exclusion were trial duration of less than 24 weeks or non comparable treatment regimens (for details see 'Characteristics of excluded studies').

\section{Risk of bias in included studies}

For details on methodological quality of included studies see Appendix 13 to Appendix 16.

\section{Overview}

All included trials were of a parallel study design. No crossover studies or factorial trials fulfilling the inclusion criteria were detected. Two of the 18 included studies primarily specified a noninferiority or equivalence design (Hanefeld 2007; Sutton 2002) with both trials specifying a $95 \%$ confidence interval (CI) of equivalence. The other studies investigated superiority or inferiority of rosiglitazone versus comparator compounds.

Interrater agreement for the key quality indicators randomisation, concealment of allocation and blinding was $95 \%$.

\section{Allocation}

All included studies were randomised controlled clinical trials of parallel design and randomised individuals. The method of randomisation was somewhat specified in five studies (Derosa 2004; Derosa 2006b; Goldberg 2005; Kahn 2006; Stocker 2007), four studies specified a randomisation ratio other than $1: 1$, that is randomisation numbers were a-priori not equal between rosiglitazone and comparator drugs (Hanefeld 2007; Kahn 2006; Phillips 2001; Raskin 2004).

Four studies particularized concealment of allocation (Derosa 2004; Derosa 2006a; Kahn 2006; Stocker 2007).

\section{Blinding}

Eleven studies had a double-blind, five studies an open-label design and two publications (Jung 2005; Ovalle 2004) did not lay down information on blinding. No publication reported checking of blinding conditions.

\section{Incomplete outcome data}

\section{Screened and randomised patients}

Nine studies or $50 \%$ of publications reported numbers of screened patients (Garber 2006; Goldberg 2005; Hanefeld 2007; Kahn 2006; Lebovitz 2001; Phillips 2001; Rosenstock 2006b; Stocker 2007; Yang 2002), ranging from 120 to 6676 screened patients with a median of 643 participants.

Altogether approximately 3888 participants were randomised to rosiglitazone treatment and 4544 to control therapy, summing up to 8432 individuals taking part in the included studies. A single study contributed $52 \%$ of randomised individuals (Kahn 2006).

\section{Discontinuing participants and attrition rates}

Six studies described discontinuing participants and provided some details about the reasons for terminating the trial (Goldberg 2005; Hanefeld 2007; Ko 2006; Rosenstock 2006b; Stocker 2007; Sutton 2002).

Discontinuation rates in the rosiglitazone arms varied between five and $40 \%$ (between four and $44 \%$ in control groups), with five studies reporting high drop-out rates above 20\% (Hanefeld 2007; Kahn 2006; Lebovitz 2001; Raskin 2004; Sutton 2002).

Discontinuation rates between intervention and control groups were dissimilar in six studies (Garber 2006; Hanefeld 2007; Jung 2005; Rosenstock 2006b; Stocker 2007; Sutton 2002). Five studies did not report details on attrition rates.

\section{Intention-to-treat and per-protocol analyses, missing data}

Thirteen of the 18 included studies reported an intention-totreat analysis, three trials a per-protocol evaluation and two both (Goldberg 2005; Sutton 2002). Intention-to-treat was clearly defined in 11 studies.

Six studies used the last-observation-carried-forward (LOCF) imputation method for missing data (Hanefeld 2007; Lebovitz 2001; Phillips 2001; Rosenstock 2006b; Sutton 2002). For example, a study of 12 months duration could extrapolate missing glycosylated haemoglobin A1c (HbA1c) values for randomised patients and declare these as endpoints, if the first post-randomisation HbA1c value (for example after three months) was available. Two studies used other methods for imputation. A clear definition of the LOCF population was provided by one study, only (Lebovitz 2001). 


\section{Other potential sources of bias}

\section{Definition of primary endpoint and secondary endpoints}

Ten studies clearly defined primary endpoints in association with power calculations, mostly one outcome, with one study presenting more than one parameter (Derosa 2006b).

The number of secondary endpoints, if stated as such, varied between two and 16. The total number of detailed endpoints in the included studies ranged from seven to 17 with a mean of seven endpoints. Only four studies adjusted for multiple outcomes, repeated measurements, or both (Derosa 2004; Derosa 2006b; Ko 2006; Phillips 2001).

\section{Power calculation}

Seven studies showed details of power calculation, the calculated number of participants per group ranged from 40 to approximately 1394.

\section{Compliance measures}

Five of the 18 included studies tried to investigate patients' compliance with the recommended treatments (Derosa 2004; Derosa 2006a; Derosa 2006b; Hällsten 2002; Stocker 2007).

\section{Funding}

Ten studies reported commercial funding, six publications did not indicate possible funding sources (Derosa 2004; Derosa 2006b; Ko 2006; Lebovitz 2001; Phillips 2001; Sutton 2002).

\section{Publication status}

Sixteen studies were published in peer review journals, none was circulated as a journal supplement.

\section{Effects of interventions}

\section{Baseline characteristics}

For details of baseline characteristics see Appendix 2, Appendix 3, Appendix 4 and Appendix 5.

Six studies demonstrated clinically relevant differences between intervention and control groups, for example gender ratio (Garber 2006; Kahn 2006; Ko 2006; Raskin 2004; Rosenstock 2006b; Stocker 2007). More men then women participated in the studies, in the rosiglitazone arms women's involvement ranged between $25 \%$ and $57 \%$.

The mean age of patients randomised to rosiglitazone treatment encompassed 47 to 61 years. Studies in established type 2 diabetes patients and providing disease information $(\mathrm{N}=13)$ showed a diabetes duration of four to 9 years. The main ethnic group participating in the trials consisted of white people, a few studies included other ethnic populations as well.

Pharmaco-naive patients usually constituted a minor part of the study participants, but two studies exclusively investigated this group (Hällsten 2002; Kahn 2006), including the largest trial (the ADOPT (A Diabetes Outcomes Progression Trial) study - Kahn 2006).

Most study participants with type 2 diabetes mellitus were also overweight or obese, the mean body mass indices (BMI) in patients randomised to rosiglitazone therapy ranged between 23.3 and 33.6 $\mathrm{kg} / \mathrm{m}^{2}$ (mean BMI of $29 \mathrm{~kg} / \mathrm{m}^{2}$ ).

Baseline metabolic control as measured by mean glycosylated haemoglobin A1c (HbA1c) varied in the rosiglitazone arms between $6.8 \%$ and $9.5 \%$, with a mean of $8.8 \%$.

\section{Primary outcomes}

For details of primary outcomes see Appendix 10.

\section{Mortality}

No study included mortality as a primary or secondary endpoint. The ADOPT trial investigated rosiglitazone, metformin and glyburide (glibenclamide) as initial treatment for recently diagnosed type 2 diabetes mellitus by means of a double-blind RCT involving more than 4000 patients (Kahn 2006). Eligible participants were between 30 and 75 years, with fasting plasma glucose levels between 126 to $180 \mathrm{mg} / \mathrm{dl}(7.0$ to $10.0 \mathrm{mmol} / \mathrm{L})$ and were treated by life style management only. The primary outcome was the time from randomisation to treatment failure. Treatment failure was defined as confirmed hyperglycaemia, that is fasting plasma glucose levels greater than $180 \mathrm{mg} / \mathrm{dl}$ on consecutive testing or according to the decision of an independent adjudication committee. Median duration of treatment was 4.0 years for rosiglitazone and metformin and 3.3 years for glyburide. At five years, when around $20 \%$ of the original cohort was being followed, the reported cumulative incidence of treatment failure was $15 \%$ in the rosiglitazone group and $21 \% / 34 \%$ in the metformin/glyburide group, respectively. The mean $\mathrm{HbA} 1 \mathrm{c}$ level at four years compared to max. $2 \mathrm{~g} /$ day metformin and max. $15 \mathrm{mg} /$ day glyburide, was $0.1 \%$ and $0.4 \%$ less after max. $8 \mathrm{mg} /$ day rosiglitazone therapy. Attrition rates were high in the ADOPT study: 37\%, 38\% and $44 \%$ did not finish the study in the rosiglitazone, metformin and glyburide groups. Mortality data were reported in Table 2 of the publication ('Adverse events, laboratory assessment, concomitant use of cardiovascular drugs, hospitalization, and death'): All-cause mortality was $34 / 1456(2.3 \%)$ in the rosiglitazone group, 31/1454 $(2.1 \%)$ in the metformin group and $31 / 1441(2.2 \%)$ in the glyburide group. 


\section{Morbidity}

No study included morbidity like diabetic complications as a primary or secondary endpoint. Eight studies made some statement about the number of participants who died during the course of the trial (Derosa 2004; Derosa 2006b; Goldberg 2005; Hällsten 2002; Hanefeld 2007; Kahn 2006; Stocker 2007; Yang 2002).

The ADOPT trial (Kahn 2006) reported some data in Table 2 of the publication ('Adverse events, laboratory assessment, concomitant use of cardiovascular drugs, hospitalization, and death'):

Hospitalisation for any cause was comparable between the rosiglitazone, metformin and glyburide groups $(11.6 \%, 11.8 \%$ and $10.4 \%$ of patients, respectively).

Cardiovascular disease [no (\%)] of serious / total events was increased in the rosiglitazone compared to the glyburide group:

- rosiglitazone $49(3.4)$ / $62(4.3)$

- metformin 46 (3.2) / 58 (4.0)

- glyburide 26 (1.8) / 41 (2.8)

Investigator reported total events [no (\%)] of congestive heart failure happened more often in the rosiglitazone compared to the glyburide group:

- rosiglitazone 22/1456 (1.5)

- metformin $19 / 1454(1.3)$

- glyburide $9 / 1441(0.6)$

Peripheral vascular disease [no (\%)] of serious / total events data were as follows:

- rosiglitazone $7(0.5) / 36(2.5)$

- metformin $6(0.4) / 27(1.9)$

- glyburide 4 (0.3) / 31 (2.2)

\section{Adverse events}

For details of adverse events see Appendix 6, Appendix 7, Appendix 8 and Appendix 9.

The percentage of overall adverse events was comparable between the intervention and control groups, serious adverse events appeared to happen somewhat more often after rosiglitazone treatment (median of $6 \%$ versus $4 \%$ in the control groups). Median discontinuation rate following rosiglitazone administration was also higher than after control therapy (median of $7 \%$ versus $4 \%$ ). Three studies evaluated and reported a more pronounced (apparently dose-related) decrease of haemoglobin after rosiglitazone intake in comparison to other active compounds or placebo. Haemoglobin reductions ranged between 0.5 and $1.0 \mathrm{~g} / \mathrm{dl}$.

Eleven studies evaluated body weight and observed an increase up to $5.0 \mathrm{~kg}$ after rosiglitazone treatment, four studies described changes in body mass index up to a rise of $1.5 \mathrm{~kg} / \mathrm{m}^{2}$.

Seven of the 18 included studies showed data on hypoglycaemic episodes: Compared to active monotherapy control rosiglitazone treatment resulted in somewhat lower rates of hypoglycaemia, especially when compared to sulphonylureas. Severe hypoglycaemic events were rarely reported.
Data on the specific adverse event "oedema" were available in nine of 18 studies. Overall, 4739 participants provided information on the occurrence of oedema. The total number of events was 287 in the rosiglitazone and 134 in the control groups. Pooling of the nine studies by means of fixed-effect meta-analysis revealed an odds ratio of 2.27 (95\% confidence interval (CI) 1.83 to 2.81 , $\mathrm{P}<0.00001)$. The test for heterogeneity indicated an $\mathrm{I}^{2}$-value of $53.4 \%$. The use of a random-effects model resulted in an odds ratio of 4.62 (95\% CI 2.28 to $9.38, \mathrm{P}<0.00001)$. The robustness of this result was tested by repeating the analysis using the risk ratio as a different measure of effect size, demonstrating a relative risk of 2.10 (95\% CI 1.72 to 2.55 ) for the fixed-effect model. Since oedema event rates in most studies were below $10 \%$, application of the odds ratio appeared to be the more valid parameter.

We repeated the analysis excluding the large ADOPT study which had a weight of $89.4 \%$ in the fixed-effect model. The odds ratio in the fixed-effect model now was 6.04 (95\% CI 3.31 to 11.02 , $\mathrm{P}<0.00001)$ and 6.79 (95\% CI 3.76 to $12.25, \mathrm{P}<0.00001)$. Heterogeneity decreased to an $\mathrm{I}^{2}$ of $0 \%$. The point estimate for the ADOPT study only was 1.76 (95\% CI 1.39 to 2.22 ).

Furthermore, the ADOPT study provided additional data on fracture rates:

\section{Men [n] fractures(\%)}

- rosiglitazone $32(3.95)$

- metformin $29(3.36)$

- glyburide 28 (3.35)

Women [n] fractures(\%)

\section{Total}

- rosiglitazone 60 (9.30)

- metformin 30 (5.08)

- glyburide 21 (3.47)

\section{Lower limb}

- rosiglitazone 36 (5.58)

- metformin 18 (3.05)

- glyburide 8 (1.32)

\section{Upper limb}

- rosiglitazone 22 (3.41)

- metformin 10 (1.69)

- glyburide 9 (1.49) 


\section{Spinal}

- rosiglitazone $1(0.16)$

- metformin $1(0.17)$

- glyburide $1(0.17)$

\section{Secondary outcomes}

For details of secondary outcomes see Appendix 11.

\section{Health-related quality of life}

No study investigated health-related quality of life.

\section{Costs}

Only one study reported some data on costs of rosiglitazone therapy (Rosenstock 2006b). Rosiglitazone $8 \mathrm{mg}$ /day plus $2 \mathrm{~g} /$ day metformin plus sulphonylurea agents were compared to the combination therapy 10 units/day insulin glargine plus $2 \mathrm{~g} /$ day metformin plus sulphonylurea agents. Overall, the estimated mean total cost of glycaemic control over 24 weeks was $\$ 235$ lower among participants treated with insulin glargine (\$1368) compared with rosiglitazone (\$1603).

\section{Metabolic control as measured by glycosylated haemoglobin Alc (HbAlc)}

Active glucose-lowering compounds like metformin, glibenclamide, or glimepiride resulted in similar reductions of HbAlc compared to rosiglitazone treatment.

\section{Heterogeneity}

Only adverse events (oedema) as one of our primary outcomes could be subjected to meta-analysis. Heterogeneity as indicated by $\mathrm{I}^{2}$ was $53.4 \%$ but could be significantly reduced after elimination of the biggest trial by Kahn et al (Kahn 2006).

\section{Subgroup analyses}

Not performed due to lack of data.

\section{Sensitivity analyses}

Various sensitivity analyses did not change substantially the risk estimates for development of oedema after rosiglitazone treatment.

\section{Publication bias}

Not performed due to insufficient amounts of data.

\section{DISCUSSION}

\section{Summary of main results}

This systematic review shows that published studies of at least 24 weeks rosiglitazone treatment in people with type 2 diabetes mellitus did not provide evidence that patient-oriented outcomes like mortality, morbidity, adverse effects and health-related quality of life are positively influenced by this compound. Metabolic control measured by glycosylated haemoglobin A1c (HbA1c) as a surrogate endpoint did not demonstrate clinically significant differences to other oral antidiabetic drugs. One study investigated economic costs of rosiglitazone versus insulin glargine therapy indicating lower costs of insulin glargine treatment. Occurrence of oedema was approximately doubled.

\section{New safety data}

The insulin-sensitising thiazolidinediones pioglitazone and rosiglitazone act as potent inhibitors of the peroxisome-proliferator-activator receptor (PPAR) $\gamma$. Several PPARs exist with different expressions in various tissues. Activation of PPAR $-\gamma$ by thiazolidinediones may cause an increase in bone marrow adiposity and a decrease in osteoblastogenesis, resulting in reduced bone formation. Several publications of animal and human data are available (Ali 2005; Grey 2007; Lazarenko 2007; Schwartz 2006a; Schwartz 2006b; Yaturu 2007). To our knowledge, the ADOPT (A Diabetes Outcomes Progression Trial) - Kahn 2006) study was the first randomised controlled clinical trial which demonstrated increased rates of fractures in women. According to the pharmaceutical company producing pioglitazone, a re-analysis of the PROactive (Prospective Pioglitazone Clinical Trial In Macrovascular Events) study (Dormandy 2005) showed that 44/870 (5.1\%) fractures were observed in pioglitazone treated female patients compared to $23 / 905(2.5 \%)$ controls.

It is unclear why it took so long to analyse adverse events in an appropriate way. Adverse reactions on fracture rates only showed up in a "Note added in proof" in the New England Journal of Medicine (Kahn 2006) and the PROactive study publication did not mention this side effect at all (Dormandy 2005). For an adequate analysis of possible adverse events of published and unpublished data adverse events information should be freely available to the public and researches alike which should pose no problems with nowadays information technology.

Just before finishing this review a meta-analysis on the effect of rosiglitazone on the risk of myocardial infarction and death from cardiovascular causes was published (Nissen 2007). Nissen and Wolski analysed 42 trials of rosiglitazone treatment with a study duration of more than 24 weeks. They found in the rosiglitazone group, as compared with the control group, a significant increase of the odds ratio for myocardial infarction of 1.43 (95\% confidence interval (CI) 1.03 to $1.98, \mathrm{P}=0.03$. The odds ratio for death from 
cardiovascular causes was 1.64 (95\% CI 0.98 to $2.74, \mathrm{P}=0.06)$. Consequently, the US Food and Drug Administration (FDA), the European Medicines Agency (EMEA) and GlaxoSmithKline issued statements and warnings with regards to this meta-analysis. Using the data from Nissen and Wolski we performed another meta-analysis of the myocardial infarction rates for type 2 diabetes only, analysing all studies, rosiglitazone versus monotherapy and rosiglitazone versus combination therapies (in the original publication several other conditions were included as well to investigate the overall cardiovascular risk of rosiglitazone). So far and limited to the sparse data available, we could not confirm significant differences in odds ratios of rosiglitazone versus controls. On the other hand, all odds ratios (with the exception of the comparator glyburide - three studies only) indicated an increased risk of rosiglitazone treatment, albeit not a statistically significant difference.

Moreover, it is disturbing to hear that the manufacturer of rosiglitazone (Avandia) provided the FDA with a pooled analysis of 42 RCTs in which rosiglitazone was compared to either placebo or other antidiabetic therapies in patients with type 2 diabetes. The meta-analysis suggested that patients receiving short-term (most studies were of six months duration) treatment with rosiglitazone may have a $30 \%$ greater relative risk of heart attacks and other heart-related adverse events than patients treated with placebo or another antidiabetic therapy. Questions of timing of this information and how it was circled arise. Ongoing trials using rosiglitazone (RECORD) may provide additional data but for a drug which was approved in 1999, the delay in obtaining information about the benefit-risk ratio is considerable.

The one major ongoing study (RECORD) which eventually could contribute valuable information about the role of rosiglitazone treatment in type 2 diabetes mellitus (for details see Characteristics of ongoing studies).

In the FDA statement 'FDA issues safety alert on Avandia' it is mentioned that "... other published and unpublished data from long-term clinical trials of Avandia, including an interim analysis of data from the RECORD trial (a large, ongoing, randomized open label trial) and unpublished re analyses of data from DREAM (a previously conducted placebo-controlled, randomized trial) provide contradictory evidence about the risks in patients treated with Avandia." We do hope that the conduct, analysis and interpretation of this trial will reflect high quality scientific standards and will not resemble the dishonourable events which accompanied the PROactive study (for more details, see Richter 2006). We agree with the commentators on the Nissen and Wolski publication that current drug approval for antidiabetic medications and possibly all new drugs needs to be changed (Psaty 2007). The benefit-risk ratio of rosiglitazone therapy in type 2 diabetes mellitus needs urgent clarification.

\section{Potential biases in the review process}

We focused on a minimum duration of 24 weeks rosiglitazone therapy in order to have a chance to detect clinically meaningful differences in patient-oriented parameters. Theoretically, studies of a shorter duration could demonstrate a significant impact on these outcomes but this is highly unlikely, even with regards to important adverse events.

Moreover, it was difficult to separate primary studies from companion papers because the latter quite often did not identify themselves as an additional publication of a parent study; especially authors Derosa et al did not reference multiple publications to each other (for details see 'References of included studies', primary studies are marked by an asterisk).

\section{AUTHORS, CONCLUSIONS}

\section{Implications for practice}

This systematic review shows that published studies of at least 24 weeks rosiglitazone treatment in people with type 2 diabetes mellitus did not provide evidence that patient-oriented outcomes like mortality, morbidity, adverse effects and health-related quality of life are positively influenced by this compound. Metabolic control measured by glycosylated haemoglobin A1c (HbA1c) as a surrogate endpoint did not demonstrate clinically significant differences to other oral antidiabetic drugs. Occurrence of oedema was approximately doubled. New safety data on increased rates of fractures and possibly the risk of myocardial infarction and cardiovascular disease should lead to a very cautious approach to rosiglitazone use. If possible, other antidiabetic medications should be employed.

\section{Implications for research}

Patient-oriented endpoint studies are urgently needed for the management of type 2 diabetes mellitus. The use of proxy indicators like metabolic control is not sufficient to approve drugs which many patients have to take for the rest of their lives. It appears questionable whether new studies with rosiglitazone will be ethical given the fact that less dangerous therapeutic alternatives exist.

\section{ACKNOWLEDGEMENTS}

We are grateful to Susan L Norris who kindly provided some standard text for our protocol/review templates. 


\section{R E F E R E N C E S}

\section{References to studies included in this review}

\section{Derosa 2004 \{published data only\}}

Derosa G, Cicero AFG, D'Angelo A, Gaddi A, Ragonesi PD, Piccinni MN, Salvadeo S, Ciccarelli L, Pricolo F, Ghelfi M, Ferrari I, Montagna L, Fogari R. Thiazolidinedione effects on blood pressure in diabetic patients with metabolic syndrome treated with glimepiride. Hypertension Research 2005;28(11):917-924.

* Derosa G, Cicero AFG, Gaddi A, Ragonesi PD, Fogari $\mathrm{E}$, Bertone G, et al.Metabolic effects of pioglitazone and rosiglitazone in patients with diabetes and metabolic syndrome treated with glimepiride: A twelve-month, multicenter, double-blind, randomized, controlled, parallelgroup trial. Clinical Therapeutics 2004;26(5):744-54. Derosa G, Cicero AFG, Gaddi A, Ragonesi PD, Piccinni MN, Fogari E, Salvadeo S, Ciccarelli L, Fogari R. A comparison of the effects of pioglitazone and rosiglitazone combined with glimepiride on prothrombotic state in type 2 diabetic patients with the metabolic syndrome. Diabetes Research \& Clinical Practice 2005;69(1):5-13.

Derosa 2006a \{published data only\}

Derosa G, Angelo AD, Ragonesi PD, Ciccarelli L, Piccini MN, Pricolo F, et al.Metformin-pioglitazone and metformin-rosiglitazone effects on non-conventional cardiovascular risk factors plasma level in type 2 diabetic patients with metabolic syndrome. Journal of Clinical Pharmacology and Therapeutics 2006;31:375-83.

* Derosa G, D’Angelo A, Ragonesi PD, Ciccarelli L, Piccinni MN, Pricolo F, et al.Metabolic effects of pioglitazone and rosiglitazone in patients with diabetes and metabolic syndrome treated with metformin. Internal Medicine Journal 2007;37:79-86.

Derosa 2006b \{published data only\} Derosa G, Cicero AFG, Gaddi AV, Ciccarelli L, Piccinni $\mathrm{MN}$, Salvadeo S, et al.Long-term effects of glimepiride or rosiglitazone in combination with metformin on blood pressure control in type 2 diabetic patients affected by the metabolic syndrome: a 12-month, double-blind, randomized trial. Clinical Therapeutics 2005;27(9): 1383-90.

Derosa G, Gaddi AV, Ciccarelli L, Fogari E, Ghelfi M, Ferrari I, et al.Long-term effect of glimepiride and rosiglitazone on non-conventional cardiovascular risk factors in metformin-treated patients affected by metabolic syndrome: A randomized, double-blind clinical trial. Journal of International Medical Research 2005;33(3): 284-94.

Derosa G, Gaddi AV, Piccinni MN, Ciccarelli L, Salvadeo $S$, Peros E, et al.Antithrombotic effects of rosiglitazonemetformin versus glimepiride-metformin combination therapy in patients with type 2 diabetes mellitus and metabolic syndrome. Pharmacotherapy 2005;25(5 I): 637-45.

* Derosa G, Gaddi AV, Piccinni MN, Salvadeo S, Ciccarelli
L, Fogari E, et al.Differential effect of glimepiride and rosiglitazone on metabolic control of type 2 diabetic patients treated with metformin: a randomized, doubleblind, clinical trial. Diabetes, Obesity and Metabolism 2006; 8:197-205.

\section{Garber 2006 \{published data only\}}

Garber A, Klein E, Bruce S, Sankoh S, Mohideen P. Metformin-glibenclamide versus metformin plus rosiglitazone in patients with type 2 diabetes inadequately controlled on metformin monotherapy. Diabetes, Obesity and Metabolism 2006;8:156-63.

Goldberg 2005 \{published data only\} Goldberg RB, Kendall DM, Deeg MA, Buse JB, Zagar AJ, Pinaire JA, et al.A comparison of lipid and glycemic effects of pioglitazone and rosiglitazone in patients with type 2 diabetes and dyslipidemia. Diabetes Care 2005;28 (7): $1547-54$.

\section{Hanefeld 2007 \{published data only\}}

Hanefeld M, Patwardhan R, Jones NP, Rosiglitazone Clinical Trials Study Group. A one-year study comparing the efficacy and safety of rosiglitazone and glibenclamide in the treatment of type 2 diabetes. Nutrition, Metabolism, and Cardiovascular Diseases 2007;17(1):13-23.

\section{Hällsten 2002 \{published data only\}}

Hälsten K, Virtanen KA, Lonnqvistt F, Janatuinen T, Turiceanu M, Ronnemaa T, et al.Enhancement of insulinstimulated myocardial glucose uptake in patients with Type 2 diabetes treated with rosiglitazone. Diabetic Medicine 2004;21 (12):1280-7.

* Hällsten K, Virtanen KI, Lönnqvist F, Sipilä H, Oksanen A, Viljanen $\mathrm{T}$, et al.Rosiglitazone but not metformin enhances insulin- and exercise-stimulated skeletal muscle glucose uptake in patients with newly diagnosed type 2 diabetes. Diabetes 2002;51:3479-85.

Iozzo P, Hallsten K, Oikonen V, Virtanen KA, Parkkola R, Kemppainen J, et al.Effects of metformin and rosiglitazone monotherapy on insulin-mediated hepatic glucose uptake and their relation to visceral fat in type 2 diabetes. Diabetes Care. 26 2003; Vol. 26, issue 7:2069-74.

Karlsson HK, Hallsten K, Bjornholm M, Tsuchida H, Chibalin AV, Virtanen KA, et al.Effects of metformin and rosiglitazone treatment on insulin signaling and glucose uptake in patients with newly diagnosed type 2 diabetes: a randomized controlled study. Diabetes 2005;54(5): 1459-67.

Viljanen APM, Virtanen KA, Järvisalo MJ, Hällsten K, Parkkola R, Rönnemaa T, et al.Rosiglitazone treatment increases subcutaneous adipose tissue glucose uptake in parallel with perfusion in patients with type 2 diabetes: a double-blind, randomized study with metformin. Journal of Clinical Endocrinology \& Metabolism 2005;90(12):6523-8. Virtanen KA, Hallsten K, Parkkola R, Janatuinen T, Lonnqvist $\mathrm{F}$, Viljanen T, et al.Differential effects of rosiglitazone and metformin on adipose tissue distribution 
and glucose uptake in type 2 diabetic subjects. Diabetes 2003;52:283-90.

Jung 2005 \{published data only\}

Jung HS, Youn BS, Cho YM, Yu KY, Park HJ, Shin CS, et al.The effects of rosiglitazone and metformin on the plasma concentrations of resistin in patients with type 2 diabetes mellitus. Metabolism: Clinical and Experimental 2005;54 (3):314-20

Kahn 2006 \{published data only\} Correction to Kahn, et al.N Engl J Med 355(23):2427-2443 December 7, 2006. Glycemic durability of rosiglitazone, metformin, or glyburide monotherapy. New England Journal of Medicine 2007;356(13):1387-8.

Gandhi GY, Montori VM. Glycemic durability of monotherapy for diabetes. New England Journal of Medicine 2007;356(13):1378-80.

* Kahn SE, Haffner SM, Heise MA, Herman WH, Holman RR, Jones NP, et al.ADOPT Study Group. Glycemic durability of rosiglitazone, metformin, or glyburide monotherapy. New England Journal of Medicine 2006;355 (23):2427-43.

Nathan DM. Thiazolidinediones for initial treatment of type 2 diabetes?. New England Journal of Medicine 2006; 355(23):2477-80.

Viberti G, Kahn SE, Greene DA, Herman WH, Zinman B, Holman RR, et al.A Diabetes Outcome Progression Trial (ADOPT): An international multicenter study of the comparative efficacy of rosiglitazone, glyburide, and metformin in recently diagnosed type 2 diabetes. Diabetes Care 2002;25:1737-43.

Viberti G, Lachin J, Holman R, Zinman B, Haffner S, Kravitz MA, et al.A Diabetes Outcome Progression Trial (ADOPT): baseline characteristics of Type 2 diabetic patients in North America and Europe. Diabetic Medicine 2006;23(12):1289-94.

Ko 2006 \{published data only\}

Ko GT, Tsang PC, Wai HP, Kan EC, Chan HC. Rosiglitazone versus bedtime insulin in the treatment of patients with conventional oral antidiabetic drug failure: a 1-year randomized clinical trial. Advances in Therapy 2006; 23(5):799-808

Lebovitz 2001 \{published data only\}

Haffner SM, Greenberg AS, Weston WM, Chen H, Williams K, Freed MI. Effect of rosiglitazone treatment on nontraditional markers of cardiovascular disease in patients with type 2 diabetes mellitus. Circulation 2002;106(6): 679-84.

* Lebovitz HE, Dole JF, Patwardhan R, Rappaport EB, Freed MI. Rosiglitazone monotherapy is effective in patients with type 2 diabetes. Journal of Clinical Endocrinology \& Metabolism 2001;86(1):280-8.

Ovalle 2004 \{published data only\}

Ovalle F, Bell DSH. Effect of rosiglitazone versus insulin on the pancreatic beta-cell function of subjects with type 2 diabetes. Diabetes Care 2004:27(11):2585-9.
Phillips 2001 \{published data only\}

Phillips LS, Grunberger G, Miller E, Patwardhan R, Rappaport EB, Salzman A. Once- and twice-daily dosing with rosiglitazone improves glycemic control in patients with type 2 diabetes. Diabetes Care 2001;24(2):308-15.

Raskin 2004 \{published data only\} Raskin P, McGill J, Saad MF, Cappleman JM, Kaye W, Khutoryansky $\mathrm{N}$ et al - for the Repaglinide/Rosiglitazone Study Group. Combination therapy for type 2 diabetes: repaglinide plus rosiglitazone. Diabetic Medicine 2004;21: 329-35.

Rosenstock 2006b \{published data only\} Rosenstock J, Sugimoto D, Strange P, Stewart JA, SoltesRak E, Dailey G - on behalf of the Insulin Glargine 4014 Study Investigators. Insulin glargine or rosiglitazone added to combination therapy of sulfonylurea plus metformin in insulin-naive patients. Diabetes Care 2006;29:554-9.

\section{Stocker 2007 \{published data only\}}

Stocker DJ, Taylor AJ, Langley RW, Jezior MR, Vigersky RA. A randomized trial of the effects of rosiglitazone and metformin on inflammation and subclinical atherosclerosis in patients with type 2 diabetes. American Heart Journal 2007;153(3):445.e1-6.

Sutton 2002 \{published data only\}

Bakris G, Viberti G, Weston WM, Heise M, Porter LE, Freed MI. Rosiglitazone reduces urinary albumin excretion in type II diabetes. Journal of Human Hypertension 2003;17 (1):7-12.

* John Sutton M, Rendell M, Dandona P, Dole JF, Murphy $\mathrm{K}$, Patwardhan R, et al.A comparison of the effects of rosiglitazone and glyburide on cardiovascular function and glycemic control in patients with type 2 diabetes. Diabetes Care 2002;25(11):2058-64.

Yang 2002 \{published data only\} Yang W-S, Jeng C-Y, Wu T-J, Tanaka S, Funahashi T, Matsuzawa Y, et al.Synthetic peroxisome proliferatoractivated receptor-gamma agonist, rosiglitazone, increases plasma levels of adiponectin in type 2 diabetic patients. Diabetes Care 2002;25(2):376-80.

\section{References to studies excluded from this review}

\section{Bailey 2005 \{published data only\}}

Bailey CJ, Bagdonas A, Rubes J, McMorn SO, Donaldson J, Biswas N, et al.Rosiglitazone/metformin fixed-dose combination compared with uptitrated metformin alone in type 2 diabetes mellitus: a 24-week, multicenter, randomized, double-blind, parallel-group study. Clinical Therapeutics 2005;27(10):1548-61.

\section{Baksi 2004 \{published data only\}} Baksi A, James RE, Zhou B, Nolan JJ. Comparison of uptitration of gliclazide with the addition of rosiglitazone to gliclazide in patients with type 2 diabetes inadequately controlled on half-maximal doses of a sulphonylurea. Acta Diabetologica 2004;41(2):63-9. [MEDLINE: 474] 
Barnett 2003 \{published data only\}

Barnett AH, Grant PJ, Hitman GA, Mather H, Pawa M, Robertson L, et al.Rosiglitazone in Type 2 diabetes mellitus: An evaluation in British Indo-Asian patients. Diabetic Medicine 2003;20(5):387-93.

Dailey 2004 \{published data only\}

Dailey III GE, Noor MA, Park J-S, Bruce S, Fiedorek FT. Glycemic control with Glyburide/Metformin tablets in combination with rosiglitazone in patients with type 2 diabetes: A randomized, double-blind trial. American Journal of Medicine 2004;116(4):223-29.

Fonseca 2000 \{published data only\}

Desouza C, Fonseca VA. Insulin sensitizer combination therapy for type 2 diabetes. Cardiology Review 2001;18(1): $11-15$.

* Fonseca V, Rosenstock J, Patwardhan R, Salzman A. Effect of metformin and rosiglitazone combination therapy in patients with type 2 diabetes mellitus: A randomized controlled trial. Journal of the American Medical Association 2000;283(13):1695-1702.

Fonseca 2003 \{published data only\}

Fonseca V, Grunberger G, Gupta S, Shen S, Foley JE. Addition of nateglinide to rosiglitazone monotherapy suppresses mealtime hyperglycemia and improves overall glycemic control. Diabetes Research and Clinical Practice 2003;26(6):1685-90.

Gomez-Perez 2002 \{published data only\}

Gomez-Perez FJ, Fanghanel-Salmon G, Barbosa JA, Montes-Villarreal J, Berry RA, Warsi G, et al.Efficacy and safety of rosiglitazone plus metformin in Mexicans with type 2 diabetes. Diabetes/Metabolism Research Reviews 2002; 18(2):127-34.

Hubacek 2004 \{published data only\}

Hubacek J, Verma S, Shewchuk L, Ross SJ, Edwards A, Anderson TJ. Rationale and design of the Glitazones and the Endothelium (GATE) study: evaluation of rosiglitazone on endothelial function in patients with diabetes. Canadian Journal of Cardiology 2004;20(14):1449-53.

Kerenyi 2004 \{published data only\}

Kerenyi Z, Samer H, James R, Yan Y, Stewart M. Combination therapy with rosiglitazone and glibenclamide compared with upward titration of glibenclamide alone in patients with type 2 diabetes mellitus. Diabetes Research and Clinical Practice 2004;63(3):213-23.

McCluskey 2004 \{published data only\}

McCluskey D, Touger MS, Melis R, Schleusener DS, McCluskey D. Results of a randomized, double-blind, placebo-controlled study administering glimepiride to patients with type 2 diabetes mellitus inadequately controlled with rosiglitazone monotherapy. Clinical Therapeutics 2004;26(11):1783-90.

Negro 2005 \{published data only\}

Negro R, Mangieri T, Dazzi D, Pezzarossa A, Hassan H. Rosiglitazone effects on blood pressure and metabolic parameters in nondipper diabetic patients. Diabetes Research and Clinical Practice 2005;70:20-5.
Raskin 2001 \{published data only\}

Raskin P, Rendell M, Riddle MC, Dole JF, Freed MI, Rosenstock J - Rosiglitazone-Clinical-Trials-Study-Group. A randomized trial of rosiglitazone therapy in patients with inadequately controlled insulin-treated type 2 diabetes. Diabetes Care 2001;24:1226-32.

Reynolds 2002 \{published data only\}

Reynolds LR, Konz EC, Frederich RC, Anderson JW. Rosiglitazone amplifies the benefits of lifestyle intervention measures in long-standing type 2 diabetes mellitus. Diabetes, Obesity \& Metabolism 2002;4(4):270-5.

Rosenstock 2006a \{published data only\} Herman WH, Dirani RG, Horblyuk R, O'Neill MC, Kravitz B, Heise MA et al - and the RESULT Study Group. Reduction in use of healthcare services with combination sulfonylurea and rosiglitazone: findings from the Rosiglitazone Early vs SULfonylurea Titration (RESULT) Study. American Journal of Managed Care 2005; 11(4):273-8.

* Rosenstock J, Goldstein BJ, Vinik AI, O’Neill MO, Porter LE, Heise MA et al - and the RESULT Study Group. Effect of early addition of rosiglitazone to sulphonylurea therapy in older type 2 diabetes patients ( $>60$ years): the Rosiglitazone Early vs SULphonylurea Titration (RESULT) study. Diabetes, Obesity and Metabolism 2006;8:49-57.

Tan 2005a \{published data only\}

Tan GD, Fielding BA, Currie JM, Humphreys SM, Desage $\mathrm{M}$, Frayn $\mathrm{KN}$, et al.The effects of rosiglitazone on fatty acid and triglyceride metabolism in type 2 diabetes. Diabetologia 2005;48(1):83-95.

Tan 2005b \{published data only\}

Tan GD, Debard C, Funahashi T, Humphreys SM, Matsuzawa Y, Frayn KN, et al.Changes in adiponectin receptor expression in muscle and adipose tissue of type 2 diabetic patients during rosiglitazone therapy. Diabetologia 2005;48(8):1585-9.

Vongthavaravat 2002 \{published data only\}

Vongthavaravat V, Wajchenberg BL, Waitman JN, Quimpo JA, Menon PS, Ben KF, et al.An international study of the effects of rosiglitazone plus sulphonylurea in patients with type 2 diabetes. Current Medical Research and Opinion 2002;18(8):456-61.

Wang 2005 \{published data only\} Wang G, Wei J, Guan Y, Jin N, Mao J, Wang X. Peroxisome proliferator-activated receptor-gamma agonist rosiglitazone reduces clinical inflammatory responses in type 2 diabetes with coronary artery disease after coronary angioplasty. Metabolism 2005;54(5):590-7.

Weissman 2005 \{published data only\} Weissman P, Goldstein BJ, Rosenstock J, Waterhouse B, Cobitz AR, Wooddell MJ, et al.Effects of rosiglitazone added to submaximal doses of metformin compared with dose escalation of metformin in type 2 diabetes: the EMPIRE Study. Current Medical Research and Opinion 2005;21(12):2029-35. 
Wolffenbuttel 2000 \{published data only\}

Wolffenbuttel BHR, Gomis R, Squatrito S, Jones NP, Patwardhan RN. Addition of low-dose rosiglitazone to sulphonylurea therapy improves glycaemic control in Type 2 diabetic patients. Diabetic Medicine 2000;17(1):40-7.

Wong 2005 \{published data only\} Wong TYH, Szeto CC, Chow KM, Leung CB, Lam CWK, Li PKT. Rosiglitazone reduces insulin requirements and creactive protein levels in type 2 diabetic patients receiving peritoneal dialysis. American Journal of Kidney Diseases 2005;46(4):713-9.

Zhu 2003 \{published data only\} Zhu X-X, Pan C-Y, Li G-W, Shi H-L, Tian H, Yang W$\mathrm{Y}$, et al.Addition of rosiglitazone to existing sulfonylurea treatment in Chinese patients with type 2 diabetes and exposure to hepatitis B or C. Diabetes Technology \& Therapeutics 2003;5(1):33-42.

\section{References to ongoing studies}

\section{RECORD \{published data only\}}

Home PD, Pocock SJ, Beck-Nielsen H, Gomis R, Hanefeld M, Dargie H, et al.Rosiglitazone evaluated for cardiac outcomes and regulation of glycaemia in diabetes (RECORD): study design and protocol. Diabetologia 2005; 48:1726-35.

\section{Additional references}

\section{ADA 1997}

American Diabetes Association. Report on the Expert Committee on the Diagnosis and Classification of Diabetes Mellitus. Diabetes Care 1997;20 Suppl 1:S5-20.

\section{ADA 1999}

The Expert Committee on the Diagnosis and Classification of Diabetes Mellitus. Report of the Expert Committee on the diagnosis and classification of diabetes mellitus. Diabetes Care 1999;22 Suppl 1:S5-19.

\section{Ali 2005}

Ali AA, Weinstein RA, Stewart SA, Parfitt AM, Manolagas SC, Jilka RL. Rosiglitazone causes bone loss in mice by suppressing osteoblast differentiation and bone formation. Endocrinology 2005;146:1226-35.

\section{Armour 2004}

Armour T, Norris S, Brown D, Zhang X, Caspersen C. Initiating and maintaining physical activity for type 2 diabetes mellitus. Cochrane Database of Systematic Reviews 2004, Issue 1.

Black 2003

Black C, McIntyre L, Mesa-Perez JA, Royle PL, Thomas $\mathrm{S}$, Waugh N. Meglitinide analogues for type 2 diabetes mellitus. Cochrane Database of Systematic Reviews 2003, Issue 4.[Art. No.: CD004654. DOI: 10.1002/ 14651858.CD004654.pub2]

Bloomgarden 2005

Bloomgarden ZT. Thiazolidinediones. Diabetes Care 2005; 28(2):488-93.

\section{Boucher 2002}

Boucher M, McAuley L, Brown A, Keely E, Skidmore B. Comparative clinical and budget evaluations of rosiglitazone and pioglitazone with other anti-diabetic agents. Ottawa, Canada: Canadian Coordinating Office for Health Technology Assessment, 2002.

\section{Boucher 2003}

Boucher M, McAuley L, Brown A, Keely E, Skidmore B. Efficacy of rosiglitazone and pioglitazone compared to other anti-diabetic agents: systematic review and budget impact analysis. Ottawa, Canada: Canadian Office for Health Technology Assessment, 2003.

Burt 2005

Burt AL, Green S, Kwan I, Mugglestone M, Thomas J. Intranasal insulin for type 1 diabetes mellitus. Cochrane Database of Systematic Reviews 2005, Issue 2.

\section{Chiquette 2004}

Chiquette E, Ramirez G, DeFronzo R. A meta-analysis comparing the effect of thiazolidinediones on cardiovascular risk factors. Archives of Internal Medicine 2004;164(19): 2097-104.

\section{Cohen 1960}

Cohen J. A coefficient of agreement for nominal scales. Educational and Psychological Measurement 1960;20:37-46.

\section{Colucciello 2005}

Colucciello M. Vision loss due to macular edema induced by rosiglitazone treatment of diabetes mellitus. Archives of Ophthalmology 2005;123(9):1273-5.

Cox 2004

Cox SL. Rosiglitazone maleate/metformin hydrochloride: A new formulation therapy for type 2 diabetes. Drugs of Today 2004;40(7):633-43.

Czoski-Murray 2004

Czoski-Murray C, Warren E, Chilcott J, Beverley C, Psyllaki MA, Cowan J. Clinical effectiveness and cost-effectiveness of pioglitazone and rosiglitazone in the treatment of type 2 diabetes: A systematic review and economic evaluation. Winchester, England: Health Technology Assessment, 2004.

\section{DCCT 1993}

The diabetes control and complications trial research group. The effect of intensive treatment of diabetes on the development and progression of long-term complications in insulin-dependent diabetes mellitus. The New England Journal of Medicine 1993;329(14):977-86.

DeFronzo 1992

DeFronzo RA, Bonadonna RC, Ferrannini E. Pathogenesis of NIDDM: a balanced overview. Diabetes Care 1992;15: 318-68.

\section{Dormandy 2005}

Dormandy JA, Charbonnel B, Eckland DJ, Erdmann E, Massi-Benedetti M, Moules IK, et al.Secondary prevention of macrovascular events in patients with type 2 diabetes in the PROactive Study (PROspective pioglitAzone Clinical Trial in macroVascular Events): A randomised controlled trial. Lancet 2005;366(9493):1279-89. 


\section{Ewart 2001}

Ewart RM. The case against aggressive treatment of type 2 diabetes: critique of the UK prospective diabetes study. BMJ 2001;323(7317):854-8.

Freemantle 2003

Freemantle N, Calvert M, Wood J, Eastaugh J, Griffin C. Composite outcomes in randomized trials: greater precision but with greater uncertainty?. JAMA 2003;289 (19):2554-9.

Gimenez-Perez 2001

Gimenez-Perez G, Gonzalez-Clemente JM, Mauricio D. Lifestyle interventions for preventing type 2 diabetes mellitus. Cochrane Database of Systematic Reviews 2001, Issue 1.

Grey 2007

Grey A, Bolland M, Gamble G, Wattie D, Horne A, Davidson J, et al.The peroxisome proliferatoractivated receptor-gamma agonist rosiglitazone decreases bone formation and bone mineral density in healthy postmenopausal women: a randomized, controlled trial. Journal of Clinical Endocrinology and Metabolism 92;4: 1305-10.

\section{Haffner 1998}

Haffner SM, Lehto S, Ronnemaa T, Pyorala K, Laakso M. Mortality from coronary heart disease in subjects with type 2 diabetes and in nondiabetic subjects with and without prior myocardial infarction. New England Journal of Medicine 1998;339:229-34.

HDS 1993

The Hypertension in Diabetes Study Group. Hypertension in diabetes study (HDS): I. Prevalence of hypertension in newly presenting type 2 diabetic patients and the association with risk factors for cardiovascular and diabetic complications. Journal of Hypertension 1993;11:309-17.

\section{Higgins 2002}

Higgins JPT, Thompson SG. Quantifying heterogeneity in a meta-analysis. Statistics in medicine 2002;21:1539-58.

Higgins 2003

Higgins JPT, Thompson SG, Deeks JJ, Altman DG. Measuring inconsistency in meta-analysis. BMJ 2003;327: $557-60$.

\section{Higgins 2005}

Higgins JPT, Green S, editors. Cochrane Handbook for Systematic Reviews of Interventions 4.2.5 [updated May 2005]. In: The Cochrane Library, Issue 3, 2005. Chichester, UK: John Wiley \& Sons, Ltd.

Kahn 1997

Kahn SE, Porte D Jr. The pathophysiology of type II (noninsulindependent) diabetes mellitus: implications for treatment. In: Porte D Jr, Sherwin RS editor(s). Ellenberg \& Rifkin's Diabetes Mellitus. 5th Edition. Stamford, Conneticut (U.S.A.): Appleton \& Lange, 1997.

Kreider 2002

Kreider M, Heise M. Rosiglitazone in the management of older patients with type 2 diabetes mellitus. International Journal of Clinical Practice 2002;56(7):538-41.
Laakso 1999

Laakso M. Hyperglycemia and cardiovascular disease in type 2 diabetes. Diabetes 1999;48:937-42.

\section{Lau 2006}

Lau J, Ioannidis JPA, Terrin N, Schmid CH, Olkin I. The case of the misleading funnel plot. BMJ 2006;333: 597-600.

Lazarenko 2007

Lazarenko OP, Rzonca SO, Hogue WR, Swain FL, Suva LJ, Lecka-Czernik B. Rosiglitazone induces decreases in bone mass and strength that are reminiscent of aged bone. Endocrinology 2007;148(6):2669-80.

\section{Lebovitz 2002}

Lebovitz HE, Kreider M, Freed MI. Evaluation of liver function in type 2 diabetic patients during clinical trials: evidence that rosiglitazone does not cause hepatic dysfunction. Diabetes Care 2002;25:815-21.

\section{Lindberg 2002}

Lindberg G, Lindblad U, Melander A. Sulfonylureas for treating type 2 diabetes mellitus. Cochrane Database of Systematic Reviews 2002, Issue 4.

\section{Malinowski 2000}

Malinowski JM, Bolesta S. Rosiglitazone in the treatment of type 2 diabetes mellitus: A critical review. Clinical Therapeutics 2000;22(10):1151-68.

\section{Manson 1991}

Manson JE, Coldlitz GA, Stampfer MJ, Willet WC, Krolewski AS, Rosner B, et al.A prospective study of maturity-onset diabetes mellitus and risk of coronary heart disease and stroke in women. Archives of Internal Medicine 1991;151:1141-7.

\section{Marcy 2004}

Marcy TR, Britton ML, Blevins SM. Second-generation thiazolidinediones and hepatotoxicity. The Annals of Pharmacotherapy 2004;38(9):1419-23.

\section{McAlister 2003}

McAlister FA, Straus SE, Sackett DL, Altman DG. Analysis and reporting of factorial trials: a systematic review. JAMA 2003;289(19):2545-53.

McCormack 2003

McCormack J, Greenhalgh T. Seeing what you want to see in randomised controlled trials: versions and perversions of UKPDS data. United Kingdom prospective diabetes study. $B M J$ 2000;320(7251):1720-3.

\section{Menees 2005}

Menees SB, Anderson MA, Chensue SW, Moseley RH. Hepatic injury in a patient taking rosiglitazone. Journal of Clinical Gastroenterology 2005;39(7):638-40.

\section{Meriden 2004}

Meriden T. Progress with thiazolidinediones in the management of type 2 diabetes mellitus. Clinical Therapeutics 2004;26(2):177-90.

\section{Misso 2005}

Misso ML, O’Connor DA, Egberts KJ, Shaw J. Continuous subcutaneous insulin infusion (CSII) versus multiple insulin 
injections for type 1 diabetes mellitus. Cochrane Database of Systematic Reviews 2005, Issue 1.[Art. No.: CD005103. DOI: 10.1002/14651858.CD005103.pub2]

\section{Moher 1999}

Moher D, Cook DJ, Eastwood S, Olkin I, Rennie D, Stroup DF. Improving the quality of reports of meta-analyses of randomised controlled trials: the QUOROM statement. Quality of Reporting of Meta-analyses. Lancet 1999;354 (9193):1896-900.

\section{Montgomery 2003}

Montgomery AA, Peters TJ, Little P. Design, analysis and presentation of factorial randomised controlled trials. $B M J$ 2003;3:26.

\section{Moore 2005}

Moore H, Summerbell C, Hooper, L, Ashton V, Kopelman P. Dietary advice for the prevention of type 2 diabetes mellitus in adults. Cochrane Database of Systematic Reviews 2005, Issue 1.[Art. No.: CD005102. DOI: 10.1002/ 14651858.CD005102.pub2]

\section{Mukhtar 2005}

Mukhtar R, Reckless JPD. Dyslipidaemia in type 2 diabetes: effects of the thiazolidinediones pioglitazone and rosiglitazone. Diabetic Medicine 2005;22:6-10.

\section{Nathan 1998}

Nathan DM. Some answers, more controversy, from UKPDS. United Kingdom Prospective Diabetes Study. Lancet 1998;352(9131):832-3.

\section{NICE 2000}

Guidance on rosiglitazone for Type 2 diabetes mellitus. London: National Institute for Clinical Excellence, 2000.

\section{NICE 2003}

Guidance on the use of glitazones for the treatment of type 2 diabetes. London: National Institute for Clinical Excellence, 2003.

\section{NICE 2003b}

Review of rosiglitazone and pioglitazone for type II diabetes - appraisal (project). London: National Institute for Clinical Excellence, 2003.

\section{Nissen 2007}

Nissen SE, Wolski K. Effect of rosiglitazone on the risk of myocardial infarction and death from cardiovascular causes. New England Journal of Medicine 2007;356:www.nejm.org (10.1056/NEJMoa072761).

Ohkubo 1995

Ohkubo Y, Kishikawa H, Araki E, Miyata T, Isami S, Motoyoshi S, et al.Intensive insulin therapy prevents the progression of diabetic microvascular complications in Japanese patients with non-insulin-dependent mellitus: a randomized prospective 6-year study. Diabetes Research and Clinical Practice 1995;28:103-17.

\section{Psaty 2007}

Psaty BM, Furberg CD. Rosiglitazone and cardiovascular risk. New England Journal of Medicine 2007;356: www.nejm.org (10.1056/NEJMe078099).

\section{Richter 2005}

Richter B, Neises G. 'Human' insulin versus animal insulin in people with diabetes mellitus. Cochrane Database of Systematic Reviews 2005, Issue 1.[Art. No.: CD003816. DOI: 10.1002/14651858.CD003816.pub2]

\section{Richter 2006}

Richter B, Bandeira-Echtler E, Bergerhoff K, Clar C, Ebrahim SH. Pioglitazone for type 2 diabetes mellitus. Cochrane Database of Systematic Reviews 2006, Issue 4.[Art. No.: CD006060. DOI: 10.1002/ 14651858.CD006060.pub2]

\section{Richter 2007}

Richter B, Bandeira-Echtler E, Bergerhoff K. Dipeptidyl peptidase-4 (DPP-4) inhibitors for type 2 diabetes mellitus. Cochrane Database of Systematic Reviews 2007, Issue 3.[Art. No.: CD006739. DOI: 10.1002/ 14651858.CD006739.pub2]

\section{Roberts 2005}

Roberts D, Van NW, Chang H, Pohula W, MCheang, Moffatt M, et al.Glargine versus other basal insulins (NPH, Lente, or Ultralente) for the treatment of type 1 diabetes mellitus. Cochrane Database of Systematic Reviews 2005, Issue 2.

\section{Royle 2003}

Royle P, Waugh N, McAuley L, McIntyre L, Thomas S. Inhaled insulin in diabetes mellitus. Cochrane Database of Systematic Reviews 2003, Issue 4. [Art. No.: CD003890. DOI: 10.1002/14651858.CD003890.pub3]

\section{Ruige 1997}

Ruige JB, deNeeling JND, Kostense PJ, Bouter LM, Heine RJ. Performance of an NIDDM screening questionnaire based on symptoms and risk factors. Diabetes Care 1997; 20:491-6.

Saenz 2005

Saenz A, Fernandez-Esteban I, Mataix A, Ausejo M, Roque M, Moher D. Metformin monotherapy for type 2 diabetes mellitus. Cochrane Database of Systematic Reviews 2005, Issue 3.[Art. No.: CD002966. DOI: 10.1002/ 14651858.CD002966.pub3]

\section{Salpeter 2003}

Salpeter S, Greyber E, Pasternak G, Salpeter E. Risk of fatal and nonfatal lactic acidosis with metformin use in type 2 diabetes mellitus. Cochrane Database of Systematic Reviews 2003, Issue 3.[Art. No.: CD002967. DOI: 10.1002/ 14651858.CD002967.pub3]

\section{Schwartz 2006a}

Schwartz AV, Sellmeyer DE, Vittinghoff E, Palermo L, Lecka-Czernik B, Feingold KR, et al.Thiazolidinedione use and bone loss in older diabetic adults. Journal of Clinical Endocrinology and Metabolism 2006;91:3349-54.

Schwartz 2006b Schwartz AV. Diabetes, TZDs, and bone: A review of the clinical evidence. PPAR Research 2006;19:1-6.

\section{Siebenhofer 2004}

Siebenhofer A, Plank J, Berghold A, Narath M, Gfrerer R, Pieber TR. Short acting insulin analogues versus regular 
human insulin in patients with diabetes mellitus. Cochrane Database of Systematic Reviews 2004, Issue 4.[Art. No.: CD003287. DOI: 10.1002/14651858.CD003287.pub4]

Snaith 2007

Snaith A, McIntyre L, Rothnie H, Thomas S, Royle P, Waugh N. Glucagon-like peptide analogues for type 2 diabetes mellitus. Cochrane Database of Systematic Reviews 2007, Issue 1.[Art. No.: CD006423. DOI: 10.1002/ 14651858.CD006423]

\section{Stamler 1993}

Stamler J, Vaccaro O, Neaton JD, Wentworth D. Diabetes, other risk factors, and 12-year cardiovascular mortality for men screened in the multiple risk factor intervention trial. Diabetes Care 1993;16:434-44.

\section{Sterne 2001}

Sterne JAC, Egger M, Davey Smith G. Investigating and dealing with publication and other biases. In: Egger M, Davey Smith G, Altman DG editor(s). Systematic Reviews in Health Care; Meta-analysis in Context. London: BMJ Publishing Group, 2001:189-208.

\section{Stratton 2000}

Stratton IM, Adler AI, Neil HA, Matthews DR, Manley SE, Cull CA, et al.Association of glycaemia with macrovascular and microvascular complications of type 2 diabetes (UKPDS 35): prospective observational study. BMJ 2000; 321(7258):405-12.

\section{Su 2006}

Su DH, Lai MY, Wu HP. Liver failure in a patient receiving rosiglitazone therapy. Diabetic Medicine 2006;23(1):105-6.

\section{Tang 2000}

Tang JL, Liu JLY. Misleading funnel plot for detection of bias in meta-analysis. Journal of Clinical Epidemiology 2000; 53:477-84.

Thomas 2001

Thomas D, Elliott E. Exercise for type 2 diabetes mellitus. Cochrane Database of Systematic Reviews 2001, Issue 1.[Art. No.: CD002968. DOI: 10.1002/ 14651858.CD002968.pub2]

\section{Thornton 2000}

Thornton A, Lee P. Publication bias in meta-analysis: its causes and consequences. Journal of Clinical Epidemiology 2000;53:207-16.

\section{UGDP 1982}

University Group Diabetes Program. Effects of hypoglycemic agents on vascular complications in patients with adult-onset diabetes, VIII. Evaluation of insulin therapy: final report. Diabetes 1982;31 Suppl 5:1-81.

\section{UKPDS-16 1995}

U.K. Prospective Diabetes Study Group. U.K. prospective diabetes study 16: overview of 6 years' therapy of type II diabetes: a progressive disease. Diabetes 1995;44:1249-58.

\section{UKPDS-33 1998}

UK Prospective Diabetes Study Group. Intensive bloodglucose control with sulphonylureas or insulin compared with conventional treatment and risk of complications in patients with type 2 diabetes-UKPDS 33. Lancet 1998;352: 837-52.

\section{UKPDS-34 1998}

UK Prospective Diabetes Study Group. Effect of intensive blood-glucose control with metformin on complications in overweight patients with type 2 diabetes. Lancet 1998;352: 854-65.

\section{UKPDS-38 1998}

UK Prospective Diabetes Study Group. Tight blood pressure control and risk of macrovascular and microvascular complications in type 2 diabetes: UKPDS 38. BMJ 1998; 317(7160):703-13.

\section{Van de Laar 2005}

Van de Laar FA, Lucassen PLBJ, Akkermans RP, Van de Lisdonk EH, Rutten GEHM, Van WC. Alpha-glucosidase inhibitors for type 2 diabetes mellitus. Cochrane Database of Systematic Reviews 2005, Issue 2.[Art. No.: CD003639. DOI: 10.1002/14651858.CD003639.pub2]

\section{Wagstaff 2002}

Wagstaff AJ, Goa KL. Rosiglitazone: A review of its use in the management of type 2 diabetes mellitus. Drugs 2002;62 (12):1805-37.

\section{Warram 1990}

Warram JH, Martin BC, Krolewski AS, Soeldner JS, Kahn CR. Slow glucose removal rate and hyperinsulinemia precede the development of Type 2 diabetes in the offspring of diabetic parents. Annals of Internal Medicine 1990;113: 909-15.

\section{Wellington 2005}

Wellington K. Rosiglitazone/Metformin. Drugs 2005;65 (11):1581-92.

WHO 1980

WHO Expert Committee on Diabetes Mellitus. Geneva: World Health Organisation, 1980. Second report. Technical Report Series 646.

\section{WHO 1985}

WHO Expert Committee on Diabetes Mellitus. Geneva: World Health Organization, 1985. Technical Report Series $727 .$.

\section{WHO 1998}

Alberti KM, Zimmet PZ. Definition, diagnosis and classification of diabetes mellitus and its compliactions. Part I: diagnosis and classification of diabetes mellitus. Provisional report of a WHO consultation. Diabetic Medicine 1998;15:539-53.

\section{Yang 2001}

Yang C, Chang TJ, Chang JC, Liu MW, Tai TY, Hsu WH, et al.Rosiglitazone (BRL 49653) enhances insulin secretory response via phosphatidylinositol 3-kinase pathway. Diabetes 2001;50:2598-602.

\section{Yaturu 2007}

Yaturu S, Bryant B, Jain SK. Thiazolidinediones treatment decreases bone mineral density in type 2 diabetic men. Diabetes Care 2007;0:dc06-2606v1-0.

* Indicates the major publication for the study 


\section{CHARACTERISTICS OF STUDIES}

\section{Characteristics of included studies [ordered by study ID]}

\section{Derosa 2004}

\begin{tabular}{|c|c|}
\hline Methods & $\begin{array}{l}\text { DURATION OF INTERVENTION: } 12 \text { months } \\
\text { DURATION OF FOLLOW-UP: } \\
12 \text { months } \\
\text { RUN-IN PERIOD: none LANGUAGE OF PUBLICATION: English }\end{array}$ \\
\hline Participants & $\begin{array}{l}\text { WHO PARTCIPATED: } \\
\text { white patients with type } 2 \text { diabetes mellitus and metabolic syndrome } \\
\text { INCLUSION CRITERIA: } \\
\text { white patients of either sex and ages }>=18 \text { years; type } 2 \text { diabetes according to ADA criteria (duration }>=6 \\
\text { months); poor glycaemic control (HbA1c }>=7.5 \% \text { or }>=1 \text { adverse effect with diet and oral hypoglycaemic } \\
\text { agents (e.g. SU or metformin) given up to the maximum tolerated dose; all patients also diagnosed with } \\
\text { metabolic syndrome (National Cholesterol Education Program Adult Treatment Panel III classification; } \\
\text { triglyceridaemia (TG >=150 mg/dl) and hypertension (WHO criteria BP >=130/>=85 mmHg); fasting } \\
\text { C-peptide level >1.0 ng/ml } \\
\text { EXCLUSION CRITERIA: } \\
\text { receiving glimepiride, history of ketoacidosis, unstable or rapidly progressive diabetic retinopathy, } \\
\text { nephropathy or neuropathy; impaired hepatic function, impaired renal function, severe anaemia; severe } \\
\text { cardiovascular disease (e.g. NYHA III or IV congestive heart failure or a history of myocardial infarction } \\
\text { or stroke) or cerebrovascular conditions within } 6 \text { months before enrolment; women who were pregnant } \\
\text { or breastfeeding or of childbearing potential and not taking adequate contraceptive precautions } \\
\text { DIAGNOSTIC CRITERIA: } \\
\text { ADA } 2001 \\
\text { CO-MORBIDITIES: } \\
\text { not stated } \\
\text { CO-MEDICATIONS: } \\
40.2 \% \text { receiving antihypertensive drugs; no patient was receiving lipid-lowering or antiaggregant drugs }\end{array}$ \\
\hline
\end{tabular}

Interventions

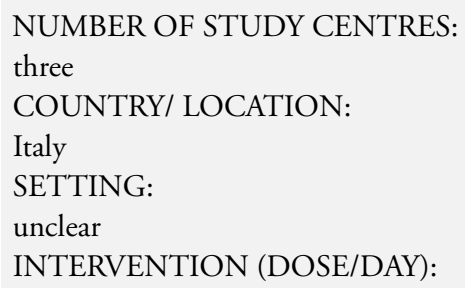


Derosa 2004 (Continued)

\begin{tabular}{|c|c|c|}
\hline & \multicolumn{2}{|c|}{$\begin{array}{l}\text { gliclazide } \\
\text { TITRATION PERIOD: } \\
\text { none }\end{array}$} \\
\hline Outcomes & \multicolumn{2}{|c|}{$\begin{array}{l}\text { PRIMARY OUTCOMES: } \\
\text { changes in BMI, HbA1c, lipid profile, and lipoprotein variables were the primary efficacy variables SEC- } \\
\text { ONDARY OUTCOMES: } \\
\text { fasting and postprandial plasma glucose, insulin levels, insulin resistance (HOMA); blood pressure; adverse } \\
\text { events }\end{array}$} \\
\hline Notes & \multicolumn{2}{|c|}{$\begin{array}{l}\text { AIM OF STUDY: } \\
\text { to assess the differential effect on glucose and lipid variables of the combination of glimepiride plus } \\
\text { pioglitazone or rosiglitazone in patients with type } 2 \text { diabetes and the metabolic syndrome }\end{array}$} \\
\hline \multicolumn{3}{|l|}{ Risk of bias } \\
\hline Item & Authors' judgement & Description \\
\hline Allocation concealment? & Yes & A - Adequate \\
\hline
\end{tabular}

Derosa 2006a

\begin{tabular}{|c|c|}
\hline Methods & $\begin{array}{l}\text { DURATION OF INTERVENTION: } \\
12 \text { months } \\
\text { DURATION OF FOLLOW-UP: } \\
12 \text { months } \\
\text { RUN-IN PERIOD: } \\
\text { none } \\
\text { LANGUAGE OF PUBLICATION: } \\
\text { English }\end{array}$ \\
\hline Participants & $\begin{array}{l}\text { WHO PARTCIPATED: } \\
\text { Caucasian patients with type } 2 \text { diabetes and poor glycaemic control with diet or experiencing adverse } \\
\text { effects with diet and metformin, administered up to the maximum tolerated dose } \\
\text { INCLUSION CRITERIA: } \\
\text { patients aged >= } 18 \text { years of either sex if they had type } 2 \text { diabetes mellitus according to the ADA (duration } \\
\text { >= } 6 \text { months), and if they had poor glycaemic control } \\
\text { (HbAlc levels > } 7.5 \% \text { ) or } \\
\text { experienced adverse effects with diet and metformin, administered up to the maximum tolerated } \\
\text { dose; all patients were diagnosed with metabolic syndrome according to the National Cholesterol } \\
\text { Education Program Adult Treatment Panel III classification and they presented with triglyceridaemia } \\
\text { (triglycerides >= } 150 \mathrm{mg} / \mathrm{dL} \text { ) and hypertension according to WHO } 1999 \text { criteria (systolic/diastolic BP >= } \\
\text { 130/ >= } 85 \text { mmHg); all patients had a fasting C-peptide level > } 1.0 \text { ng/mL and were overweight (BMI } \\
25.0 \text { - 28.1) } \\
\text { EXCLUSION CRITERIA: } \\
\text { history of ketoacidosis; unstable or rapidly progressive diabetic retinopathy, nephropathy, or neuropathy; } \\
\text { impaired hepatic function (defined as plasma aminotransferase and/or gamma-glutamyltransferase levels } \\
\text { higher than the upper limit of normal (ULN) for age and sex], impaired renal function (defined as }\end{array}$ \\
\hline
\end{tabular}


serum creatinine levels higher than the ULN for age and sex) or severe anaemia; patients with serious cardiovascular disease (e.g. NYHA class I-IV congestive heart failure or a history of myocardial infarction or stroke) or cerebrovascular conditions within 6 months before study enrollment; women who were pregnant, breastfeeding or of childbearing potential and not taking adequate contraceptive precautions DIAGNOSTIC CRITERIA:

ADA 2001

CO-MORBIDITIES:

not stated

CO-MEDICATIONS:

not stated

Interventions

NUMBER OF STUDY CENTRES:

3

COUNTRY/ LOCATION:

Italy

SETTING:

Department of Internal Medicine and Therapeutics, University of Pavia (Pavia, Italy); the 'G. Descovich' Atherosclerosis Study Center, 'D. Campanacci' Clinical Medicine and Applied Biotechnology Department, University of Bologna (Bologna, Italy); the Diabetes Care Unit at S. Carlo Hospital of Milano (Milano, Italy).

INTERVENTION (DOSE/DAY):

metformin (mean dose $2250 \mathrm{mg} /$ day) + rosiglitazone $4 \mathrm{mg} /$ day (o.d., before lunch)

CONTROL (DOSE/DAY):

metformin (mean dose $2250 \mathrm{mg} /$ day) + pioglitazone $15 \mathrm{mg} /$ day (15 mg o.d., before lunch)

TREATMENT BEFORE STUDY:

diet or diet and metformin, administered up to the maximum tolerated dose

TITRATION PERIOD:

all paitents received metformin beginning with a dose of $1500 \mathrm{mg} /$ day and increasing up to $3000 \mathrm{mg} /$ day, self-administered for 12 months, this dose depended on the tolerance or glycaemic control of the patients (mean dosage: $2250 \pm 750 \mathrm{mg} /$ day)

\section{Outcomes PRIMARY OUTCOMES:}

changes in BMI, HbAlc, lipid profile, lipoprotein variables

SECONDARY OUTCOMES:

(not stated)

"FPG, PPG and HOMA index

were also used to assess efficacy"

BMI, HbAlc, fasting and postprandial plasma glucose (FPG, PPG) and insulin levels; HOMA; lipid profile; treatment tolerability

\section{Notes $\quad$ AIM OF STUDY:}

to assess the differential effect on glucose and lipid variables of the combination of metformin plus pioglitazone or metformin plus rosiglitazone in patients with type 2 diabetes mellitus and metabolic syndrome

Risk of bias

Item

Authors' judgement

Description

Rosiglitazone for type 2 diabetes mellitus (Review) 
Derosa 2006a (Continued)

\begin{tabular}{llll} 
Allocation concealment? & Yes & A - Adequate \\
\hline
\end{tabular}

\section{Derosa 2006b}

Methods
DURATION OF INTERVENTION:

12 months

DURATION OF FOLLOW-UP:

12 months

RUN-IN PERIOD:

none

LANGUAGE OF PUBLICATION:

English
Participants

Interventions
WHO PARTCIPATED:

type 2 diabetic patients with inadequate control on diet and oral hypoglycaemic agents

INCLUSION CRITERIA:

patients with metabolic syndrome diagnosis according to National Cholesterol Education Program

(NCEP) (ATP III) classification and they presented at least three following components:

1. type 2 diabetes mellitus.

2. triglyceridemia $>=150 \mathrm{mg} / \mathrm{dl}$.

3. Blood pressure $>=130 / 85 \mathrm{mmHg}$

type 2 diabetes mellitus, according to ADA criteria; all were required to have been diagnosed as being diabetic for at least 6 months and did not have adequate glycaemic control (as suggested by ADA guidelines)

with diet and oral hypoglycaemic agents such as sulphonylureas or metformin, both to the maximum tolerated dose; no patients were taking glimepiride or thiazolidinediones; all patients had a fasting Cpeptide level > $1.0 \mathrm{ng} / \mathrm{ml}$; mean BMI of 25.3 ;

furthermore, patients were hypertensive according to the WHO 1999 criteria (systolic BP $>=130 \mathrm{mmHg}$ and diastolic $\mathrm{BP}>=85 \mathrm{~mm} \mathrm{Hg}$ ) and had triglyceridaemia $>=150 \mathrm{mg} / \mathrm{dl}$

EXCLUSION CRITERIA:

history of ketoacidosis; unstable or rapidly progressive diabetic background retinopathy,

nephropathy (microalbuminuria, evaluated by proteinuria $<300 \mathrm{mg} / 24 \mathrm{~h}$ ) or neuropathy (evaluated by electromyography); impaired liver function (transaminases $>40 \mathrm{U} / \mathrm{L}$ ), impaired kidney function (creatinine $>1.5 \mathrm{mg} / \mathrm{dl}$ ) or anaemia $(\mathrm{Hb}<11.5 \mathrm{~g} / \mathrm{L})$; unstable cardiovascular conditions (e.g. NYHA class

III or IV congestive heart failure or a history of myocardial infarction or stoke) or cerebrovascular conditions within 6months of study enrolment; women who were pregnant, lactating, or of child-bearing potential while not taking adequate contraceptive precautions

DIAGNOSTIC CRITERIA:

ADA 2001

CO-MORBIDITIES:

not stated

\section{CO-MEDICATIONS:}

at entry, 42 patients (44.2\%) were taking antihypertensive drugs [16 participants, ACE-inhibitors (38. $1 \%) ; 12$ participant, calcium antagonists (28.6\%); 10 participants, AT II antagonists $(23.8 \%)$ and four patients, alpha1-antagonists $(9.5 \%)]$; no patients were taking lipid-lowering or antiaggregation drugs

\section{NUMBER OF STUDY CENTRES:}

2

COUNTRY/ LOCATION: 
Italy

SETTING:

Department of Internal Medicine and Therapeutics at University of Pavia, the G. Descovich Atherosclerosis Study Center, D. Campanacci Clinical Medicine and Applied Biotechnology Department at University of Bologna

INTERVENTION (DOSE/DAY):

rosiglitazone $4 \mathrm{mg} /$ day + metformin $1500 \mathrm{mg} /$ day

CONTROL (DOSE/DAY):

glimepiride $2 \mathrm{mg} /$ day+ metformin $1500 \mathrm{mg} /$ day

TREATMENT BEFORE STUDY:

patients did not have adequate glycaemic control with diet and oral hypoglycaemic agents such as sulphonylureas or metformin, both to the maximum tolerated dose

TITRATION PERIOD:

none

Outcomes

PRIMARY OUTCOMES:

changes in BMI, HbA1c, lipid profile and lipoprotein parameters were the primary efficacy variables SECONDARY OUTCOMES:

(not stated) height, weight, BMI, HbA1c, FPG, PPG, fasting plasma insulin; postprandial plasma insulin; lipid profile and lipoprotein parameters; HOMA; adverse events

Notes

AIM OF STUDY:

the aim of this study is to compare the metabolic changes induced by metformin associated to glimepiride or rosiglitazone in type 2 diabetic patients

\section{Risk of bias}

\begin{tabular}{l|l} 
Item Authors' judgement $\quad$ Description \\
\hline
\end{tabular}

Allocation concealment? Yes $\quad$ A - Adequate

Garber 2006

Methods

DURATION OF INTERVENTION:

24 weeks

DURATION OF FOLLOW-UP:

24 weeks

RUN-IN PERIOD:

during the 1-week, open-label lead-in phase, patients maintained their prescreening dosage of $>=1500$

$\mathrm{mg}$ /day metformin therapy; LANGUAGE OF PUBLICATION:

English

Participants

WHO PARTCIPATED:

type 2 diabetes patients inadequately controlled on metformin monotherapy.

INCLUSION CRITERIA:

adults (age 20-78 years) with established type 2 diabetes requiring oral therapy; before screening, patients were required to be on a stable dosage of metformin $>=1500 \mathrm{mg} /$ day for $>=8$ weeks, HbAlc levels $>7.0$ and $<=12.0 \%$ and $\mathrm{BMI}>=23$ and $<=45$; only patients willing and able to perform self-blood glucose; 
women of childbearing potential had to practise acceptable methods of birth control and to have negative pregnancy test results within $72 \mathrm{~h}$ of study treatment

EXCLUSION CRITERIA:

marked polyuria and polydipsia with $>10 \%$ weight loss; the use of any hypoglycaemic agent other than metformin within 8 weeks before screening; anaemia [haemoglobin level: $<12.5 \mathrm{~g} / \mathrm{dl}$ (men) and $<11.0 \mathrm{~g} /$ $\mathrm{dl}$ (women)] and significantly abnormal

renal, cardiac or hepatic dysfunction or disease; pregnant or nursing women and patients with known sensitivity to any study medications were excluded.

\section{DIAGNOSTIC CRITERIA:}

not stated

CO-MORBIDITIES:

not stated

CO-MEDICATIONS:

not stated

\section{NUMBER OF STUDY CENTRES:}

76

COUNTRY/ LOCATION:

USA

\section{SETTING:}

not stated

INTERVENTION (DOSE/DAY):

metformin $500 \mathrm{mg}$ plus rosiglitazone $4 \mathrm{mg}$ /day (initial daily dose $1000-2000 \mathrm{mg}+4 \mathrm{mg}$, depending on previous treatment)

[mean final dose of metformin plus rosiglitazone was 1819 and $7.1 \mathrm{mg}$ ]

CONTROL (DOSE/DAY):

metformin-glibenclamide 500/2.5 mg/day (initial daily dose $1000 / 5 \mathrm{mg}$ )

[mean final dose of metformin-glibenclamide tablets was $1509 / 7.6 \mathrm{mg}$ ]

TREATMENT BEFORE STUDY:

patients were required to be on a stable dosage of metformin $>=1500 \mathrm{mg} / \mathrm{day}$ for $>=8$ weeks

TITRATION PERIOD:

patients were randomly assigned to one of two double-blind treatments, according to the dose of metformin during the lead-in phase:

patients receiving $1500 \mathrm{mg} /$ day metformin before screening received metformin-glibenclamide 1000/5 $\mathrm{mg} /$ day (in divided doses) or metformin $1500 \mathrm{mg}$ plus rosiglitazone $4 \mathrm{mg}$ daily (in divided doses); those previously receiving $>1500 \mathrm{mg} /$ day were randomly assigned to metformin-glibenclamide $1000 / 5 \mathrm{mg}$ (in divided doses) or metformin $2000 \mathrm{mg}$ plus rosiglitazone $4 \mathrm{mg}$ daily (in divided doses)

study medications were titrated based on mean daily glucose levels to achieve a therapeutic glycaemic target

\section{PRIMARY OUTCOMES:}

change in HbA1c from baseline to week 24 or the last prior blinded visit SECONDARY OUTCOMES:

changes in body weight and changes in fructosamine, FPG,

2-h postprandial plasma glucose and fasting insulin levels from baseline to week 24 or the last prior blinded visit; proportion of patients achieving therapeutic glycaemic response (HbAlc levels $<7.0 \%$ and FPG levels $<7 \mathrm{mmol} / \mathrm{L}$ ) at week 24 or the

last prior blinded visit; safety outcomes included adverse events, particularly hypoglycaemic symptoms; standard haematology, serum chemistry and urinalysis 
Garber 2006 (Continued)

Notes
$\begin{aligned} & \text { AIM OF STUDY: } \\ & \text { to compare the effects of two combination regimens, metformin-glibenclamide combination tablets versus } \\ & \text { metformin plus rosiglitazone in patients inadequately controlled on metformin monotherapy }\end{aligned}$

Risk of bias

\begin{tabular}{lll} 
Item & Authors' judgement & Description \\
\hline Allocation concealment? & Unclear & B - Unclear \\
\hline
\end{tabular}

Goldberg 2005

Methods

DURATION OF INTERVENTION:

24 weeks

DURATION OF FOLLOW-UP:

24 weeks

RUN-IN PERIOD:

oral placebo; single-blind; 4 weeks LANGUAGE OF PUBLICATION:

English

Participants

WHO PARTCIPATED:

patients with type 2 diabetes mellitus who were treated with diet alone or oral monotherapy

INCLUSION CRITERIA:

men or women $>=35$ years of age with a diagnosis of type 2 diabetes (WHO) with fasting triglyceride levels $>=150 \mathrm{mg} / \mathrm{dl}$ and $<600 \mathrm{mg} / \mathrm{dl}$ and fasting LDL cholesterol levels $<130 \mathrm{mg} / \mathrm{dl}$; fasting serum C-peptide levels $>=1 \mathrm{ng} / \mathrm{ml}$ and $\mathrm{HbA} 1 \mathrm{c}$ values $>=7$ and $<=11 \%$ if naive to previous oral antihyperglycemic therapy or HbAlc values $>=7$ and $<=9.5 \%$ if previously treated with oral antihyperglycemic monotherapy.

EXCLUSION CRITERIA:

treatment within 60 days of screening with insulin, systemic glucocorticoid therapy; combination oral antihyperglycemic therapy, any lipid-lowering agent, or any weight loss agent; known allergy to any thiazolidinedione; serum creatinine $>=176.8 \mu \mathrm{mol} / \mathrm{dl}(>=2.0 \mathrm{mg} / \mathrm{dl}$ ) or $2+$ dipstick proteinuria at screening; ALT or AST $>=1.5$ times the upper limit of normal or significant clinical liver disease; hemoglobin < $10.5 \mathrm{~g} / \mathrm{dl}$ (females) or $<11.5 \mathrm{~g} / \mathrm{dl}$ (males) at screening; abnormal thyrotropin; functional NYHA class III or IV, history of CVD, or heart surgery within 6 months of screening; receiving renal dialysis or having renal transplant; current therapy for malignancy other than basal cell or squamous cell skin cancer; known history of HIV infection; signs or symptoms of drug or alcohol abuse; any condition or situation precluding adherence to and completion of the protocol. For female subjects, appropriate birth control was required, and pregnancy, breast-feeding, or the intent to become pregnant during the study period prohibited participation.

\section{DIAGNOSTIC CRITERIA:}

WHO

CO-MORBIDITIES:

control vs intervention:

- pre-existing CVD or previous myocardial infarction $8.4 \%$ vs $6.6 \%$

CO-MEDICATIONS:

not stated 


\begin{tabular}{|c|c|c|}
\hline Interventions & \multicolumn{2}{|c|}{$\begin{array}{l}\text { NUMBER OF STUDY CENTRES: } \\
100 \text { (USA 78) } \\
\text { COUNTRY/ LOCATION: } \\
\text { USA, Puerto Rico, Mexico, Colombia } \\
\text { SETTING: } \\
\text { not stated } \\
\text { INTERVENTION (DOSE/DAY): } \\
\text { rosiglitazone } 4 \text { mg daily for } 12 \text { weeks; thereafter } 4 \mathrm{mg} \text { twice daily ( } 8 \mathrm{mg} / \text { day) for } 12 \text { weeks } \\
\text { CONTROL (DOSE/DAY): } \\
\text { pioglitazone } 30 \text { mg daily for } 12 \text { weeks; thereafter } 45 \mathrm{mg} \text { once daily for } 12 \text { weeks } \\
\text { TREATMENT BEFORE STUDY: } \\
\text { participants discontinued any current oral antihyperglycaemic treatment } \\
\text { drug naive (\%) - } \\
\text { I1: } 26.5, \text { I2: } 26.6, \text { C: } 28.5 \\
\text { prior monotherapy (\%) - } \\
\text { I1: } 68.7, \text { I2: } 65.7 \text {, C1: } 63.9 \\
\text { prior combination therapy ( } \%) \text { - } \\
\text { TITRATION PERIOD } \\
\text { - pioglitazone: } 30 \text { mg daily for } 12 \text { weeks; thereafter } 45 \text { mg once daily for } 12 \text { weeks } \\
\text { - rosiglitazone: } 4 \text { mg daily for } 12 \text { weeks; thereafter } 4 \text { mg twice daily ( } 8 \text { mg/day) for } 12 \text { weeks }\end{array}$} \\
\hline Outcomes & \multicolumn{2}{|c|}{$\begin{array}{l}\text { PRIMARY OUTCOMES: } \\
\text { triglycerides change from baseline to the last observed value SECONDARY OUTCOMES: } \\
\text { total cholesterol; plasma glucose; free fatty acids; apolipoprotein B; total insulin; C-peptide; highly sensi- } \\
\text { tive C-reactive protein; plasminogen activator inhibitor-1 (PAI-1); HDL-C; LDL-C particle size and con- } \\
\text { centration; surrogates of insulin resistance and beta-cell function (HOMA); safety assessments including } \\
\text { adverse events, body weight, pedal oedema and hypoglycaemic episodes }\end{array}$} \\
\hline Notes & \multicolumn{2}{|c|}{$\begin{array}{l}\text { AIM OF STUDY: } \\
\text { to test the hypothesis that pioglitazone has greater triglyceride-lowering effects than rosiglitazone - com- } \\
\text { parison of maximally effective monotherapy doses of pioglitazone and rosiglitazone in patients with type } \\
2 \text { diabetes and dyslipidemia receiving no concomitant glucose-lowering or lipid-lowering therapies }\end{array}$} \\
\hline \multicolumn{3}{|l|}{ Risk of bias } \\
\hline Item & Authors' judgement & Description \\
\hline Allocation concealment? & Unclear & B - Unclear \\
\hline
\end{tabular}


Methods

\begin{tabular}{l}
52 weeks \\
DURATION OF FOLLOW-UP: \\
52 weeks \\
RUN-IN PERIOD: \\
eligible patients on oral antidiabetic medication stopped treatment 2 weeks before starting a 4-week, \\
single-blind placebo run-in period \\
LANGUAGE OF PUBLICATION: \\
English \\
\hline Participants \\
WHO PARTCIPATED: \\
patients with type 2 diabetes \\
INCLUSION CRITERIA: \\
FPG $=7.0$ - 15.0 mmol/L C-peptide >= 27 nmol/L; BMI = 22 - 38 \\
EXCLUSION CRITERIA: \\
patients on insulin therapy or those with diabetic complications requiring treatment, heart failure NYHA \\
III/IV, or serious renal, hepatic (liver function tests $>2.5$ times the upper limit of normal). haematologic \\
impairment or women of childbearing potential \\
DIAGNOSTIC CRITERIA: \\
see above \\
CO-MORBIDITIES: \\
not stated \\
CO-MEDICATIONS: \\
not stated
\end{tabular}

Interventions

\section{NUMBER OF STUDY CENTRES:}

71

COUNTRY/ LOCATION:

8 European countries

SETTING:

not stated

INTERVENTION (DOSE/DAY):

rosiglitazone as two equal daily doses (i.e. $2 \mathrm{mg}$ bid or $4 \mathrm{mg}$ bid) + placebo

CONTROL (DOSE/DAY):

glibenclamide once daily + placebo

TREATMENT BEFORE STUDY:

patients on monotherapy, combination therapy or diet and exercise only

TITRATION PERIOD:

over the first 12 weeks of treatment, the glibenclamide dose was titrated in $2.5 \mathrm{mg}$ increments (final dose range $=2.5-15 \mathrm{mg}$ ) to achieve optimal glycaemic

control

a double-dummy system allowed "titration"

of rosiglitazone without a change of dose

concomitant medications with potential effects on glucose or lipid metabolism were kept at constant dose throughout the study

PRIMARY OUTCOMES:

difference between rosiglitazone $8 \mathrm{mg} /$ day and glibenclamide treatment groups with respect to change from baseline in HbA1c after 52 weeks of treatment

SECONDARY OUTCOMES: 
Hanefeld 2007 (Continued)

(not stated)

lipids, insulin resistance (HOMA), insulin, proinsulin, 32-33 split proinsulin, safety, adverse effects

\section{Notes $\quad$ AIM OF STUDY:}

to compare the efficacy, tolerability and safety of rosiglitazone with that of

glibenclamide as monotherapy for patientswith type 2 diabetes over a 12-month treatment period

Risk of bias

\begin{tabular}{l|ll}
\hline Item & Author' judgement & Description \\
\hline Allocation concealment? & Unclear & B - Unclear \\
\hline
\end{tabular}

Hällsten 2002

Methods

DURATION OF INTERVENTION:

26 weeks

DURATION OF FOLLOW-UP:

26 weeks

RUN-IN PERIOD:

4-weeks with written diet instructions

LANGUAGE OF PUBLICATION:

English

WHO PARTCIPATED:
patients with newly diagnosed or diet-treated type 2 diabetes
INCLUSION CRITERIA:
patients with type 2 diabetes, as defined by the WHO criteria and no diabetes complications
EXCLUSION CRITERIA:
fasting plasma glucose value $<6.1 \mathrm{mmol} / \mathrm{l}$ or $>11.0 \mathrm{mmol} / \mathrm{L}$ after the run-in period; patients with
cardiovascular disease, blood pressure $>160 / 100 \mathrm{~mm} \mathrm{Hg}$, previous or present abnormal hepatic or renal
function, antidiabetic medication, anemia, or oral corticosteroid treatment
DIAGNOSTIC CRITERIA:
WHO 1998
CO-MORBIDITIES:
not stated
CO-MEDICATIONS:
not stated

Interventions

NUMBER OF STUDY CENTRES:

not stated (1)

COUNTRY/ LOCATION:

Finland

SETTING:

the patients were recruited by advertisement and among clients of the occupational health service in

Turku, Finland

INTERVENTION (DOSE/DAY):

rosiglitazone $8 \mathrm{mg} /$ day (4 $\mathrm{mg}$ b.i.d.) 
Hällsten 2002 (Continued)

\begin{tabular}{|c|c|c|}
\hline & \multicolumn{2}{|c|}{$\begin{array}{l}\text { CONTROL (DOSE/DAY): } \\
\text { C1: metformin } 2 \mathrm{~g} \text { (1g b.i.d.) } \\
\text { C2: placebo } \\
\text { TREATMENT BEFORE STUDY: } \\
\text { none or diet only } \\
\text { TITRATION PERIOD: } \\
\text { rosiglitazone ( } 2 \text { mg b.i.d. for } 2 \text { weeks, thereafter } 4 \mathrm{mg} \text { b.i.d.), metformin }(500 \mathrm{mg} \text { b.i.d. for } 2 \text { weeks, } \\
\text { thereafter } 1 \mathrm{~g} \text { b.i.d.), or placebo }\end{array}$} \\
\hline Outcomes & \multicolumn{2}{|c|}{$\begin{array}{l}\text { PRIMARY OUTCOMES: } \\
\text { not stated (insulin- and exercise-stimulated skeletal muscle glucose uptake, measured by means of positron } \\
\text { emission tomography (PET) during euglycemic-hyperinsulinemic } \\
\text { clamp and one-legged exercise) } \\
\text { SECONDARY OUTCOMES: } \\
\text { (not stated) } \\
\text { FPG, insulin, HbA1c, body weight, blood pressure }\end{array}$} \\
\hline Notes & \multicolumn{2}{|c|}{$\begin{array}{l}\text { AIM OF STUDY: } \\
\text { to compare the effects of treatment with rosiglitazone and metformin on insulin- and exercise-stimulated } \\
\text { glucose uptake and perfusion in skeletal muscle tissue in patients with type } 2 \text { diabetes }\end{array}$} \\
\hline \multicolumn{3}{|l|}{ Risk of bias } \\
\hline Item & Authors' judgement & Description \\
\hline Allocation concealment? & Unclear & B - Unclear \\
\hline
\end{tabular}

Jung 2005

Methods

DURATION OF INTERVENTION:

6 months

DURATION OF FOLLOW-UP:

6 months

RUN-IN PERIOD:

none

LANGUAGE OF PUBLICATION:

English

Participants

WHO PARTCIPATED:

Koreans with type 2 diabetes mellitus who showed poor glycaemic control with glimepiride INCLUSION CRITERIA:

aged 20-70 years; secondary treatment failure (HbA1c > 8\% on glimepiride $4 \mathrm{mg} /$ day or equivalent dose of other sulfonylureas)

EXCLUSION CRITERIA:

no other severe illnesses including liver failure, renal failure, heart failure

DIAGNOSTIC CRITERIA:

not stated

CO-MORBIDITIES: 


\begin{tabular}{|c|c|c|}
\hline & \multicolumn{2}{|c|}{$\begin{array}{l}\text { retinopathy - } \\
\text { I: } 3 / 14, \mathrm{C}: 3 / 13 \\
\text { proteinuria - } \\
\text { I: } 2 / 14, \mathrm{C}: 3 / 13 \\
\text { coronary heart disease - } \\
\text { I: } 2 / 14, \mathrm{C}: 2 / 13 \\
\text { CO-MEDICATIONS } \\
\text { lipid-lowering agents - } \\
\text { I: } 5 / 14, \mathrm{C}: 3 / 13\end{array}$} \\
\hline Interventions & \multicolumn{2}{|c|}{$\begin{array}{l}\text { NUMBER OF STUDY CENTRES: } \\
1 \\
\text { COUNTRY/ LOCATION: } \\
\text { Korea } \\
\text { SETTING: } \\
\text { diabetes clinic of the Seoul National University Hospital } \\
\text { INTERVENTION (DOSE/DAY): } \\
\text { rosiglitazone } 4 \mathrm{mg} / \text { day + glimepiride } 4 \mathrm{mg} / \text { day } \\
\text { CONTROL (DOSE/DAY): } \\
\text { metformin } 1000 \mathrm{mg} / \text { day + glimepiride } 4 \mathrm{mg} / \text { day } \\
\text { TREATMENT BEFORE STUDY: } \\
\text { glimepiride } 4 \mathrm{mg} / \text { day or equivalent dose of other sulfonylureas } \\
\text { TITRATION PERIOD: } \\
\text { none }\end{array}$} \\
\hline Outcomes & \multicolumn{2}{|c|}{$\begin{array}{l}\text { PRIMARY OUTCOMES: } \\
\text { not stated } \\
\text { (resistin) } \\
\text { SECONDARY OUTCOMES: } \\
\text { (not stated) } \\
\text { adiponectin, FPG, lipids, HbAlc, plasma insulin, plasma C-peptide }\end{array}$} \\
\hline Notes & \multicolumn{2}{|c|}{$\begin{array}{l}\text { AIM OF STUDY: } \\
\text { to see whether improving insulin resistance can modulate circulating resistin levels, the effects of two } \\
\text { different insulin sensitizers, rosiglitazone and metformin, on plasma resistin concentrations in Korean } \\
\text { participants with type } 2 \text { diabetes mellitus were investigated }\end{array}$} \\
\hline \multicolumn{3}{|l|}{ Risk of bias } \\
\hline Item & Authors' judgement & Description \\
\hline Allocation concealment? & Unclear & B - Unclear \\
\hline
\end{tabular}


Methods

DURATION OF INTERVENTION:

4.0 years (median)

DURATION OF FOLLOW-UP:

4.0 years (median)

RUN-IN PERIOD:

4 weeks, placebo + diet/exercise

LANGUAGE OF PUBLICATION:

English

Participants

WHO PARTCIPATED:

people with recently diagnosed type 2 diabetes mellitus, treated with life style management only INCLUSION CRITERIA:

eligible patients were between the ages of 30 and 75 years, with fasting plasma glucose levels ranging from 126 to $180 \mathrm{mg}$ per deciliter ( 7.0 to $10.0 \mathrm{mmol}$ per liter) while their only treatment was lifestyle management

\section{EXCLUSION CRITERIA:}

clinically significant hepatic disease, renal impairment, a history of lactic acidosis, unstable or severe angina, known congestive heart failure (CHF, New York Heart Association class I, II, III, or IV), or uncontrolled hypertension

DIAGNOSTIC CRITERIA:

"recently diagnosed (i.e., within 3 years)"

CO-MORBIDITIES:

not stated

CO-MEDICATIONS:

Antihypertensive therapy [no. (\%)]:

I1: 744 (51.1)

C1: 737 (50.7)

C2: 753 (52.3)

Lipid-lowering therapy [no. (\%)]

I1: 378 (26.0)

C1: 377 (25.9)

C2: 370 (25.7)

Interventions

NUMBER OF STUDY CENTRES:

488

COUNTRY/ LOCATION:

United States, Canada, and 15 European countries

SETTING:

not stated

INTERVENTION (DOSE/DAY):

rosiglitazone ( $\max 8 \mathrm{mg} /$ day)

CONTROL (DOSE/DAY):

metformin ( $\max 2 \mathrm{~g} /$ day)

glyburide (max $15 \mathrm{mg} /$ day)

TREATMENT BEFORE STUDY:

diet/exercise

TITRATION PERIOD:

patients received initial daily doses of $4 \mathrm{mg}$ of rosiglitazone, $500 \mathrm{mg}$ of metformin, or $2.5 \mathrm{mg}$ of glyburide for each drug, the dose was increased according to the protocol to the maximum daily effective dose ( 4 
$\mathrm{mg}$ of rosiglitazone twice daily, $1 \mathrm{~g}$ of metformin twice daily, and $7.5 \mathrm{mg}$ of glyburide twice daily a dose increase was required at each visit if the fasting plasma glucose level was $140 \mathrm{mg}$ per deciliter or more; a dose reduction was permitted if adverse events occurred

Outcomes Notes

\section{PRIMARY OUTCOMES:}

time from randomization to treatment failure, which was defined as confirmed hyperglycemia (fasting plasma glucose level, $>180 \mathrm{mg} / \mathrm{dl}$ ) on consecutive testing after at least 6 weeks of treatment at the maximumdictated or maximum-tolerated dose

of the study drug

an independent adjudication

committee, whose members were unaware of assignments

to treatment groups, used prespecified criteria (available

at www.nejm.org) to determine whether the primary outcome

was reached in cases in which a confirmatory fasting plasma glucose level had not been obtained, a patient had withdrawn because of an insufficient therapeutic effect, or an additional glucose lowering drug had been administered before the

confirmation of hyperglycemia (according to a protocol

amendment adopted in February 2004)

the threshold of more than $180 \mathrm{mg}$ per deciliter for confirmed hyperglycemia was selected to represent unequivocal failure in the maintenance of adequate glycemic control without incurring undue hyperglycemic symptoms; the threshold of a fasting plasma glucose level of more than

$140 \mathrm{mg}$ per deciliter for increasing the dose of a study drug reflected clinical guidelines at the time of study design.

\section{SECONDARY OUTCOMES:}

time from randomization to a confirmed fasting plasma glucose level of more than $140 \mathrm{mg}$ per deciliter after at least 6 weeks of treatment at the

maximum-tolerated dose of a study drug (for patients who entered the study with a fasting plasma glucose level of $140 \mathrm{mg}$ per deciliter or less)

other prespecified outcomes were levels of fasting plasma

glucose and glycated hemoglobin, weight, and

measures of insulin sensitivity and beta-cell function, as determined by homeostasis model assessment (HOMA 2) with the use of the HOMA calculator (www.dtu.ox.ac.uk)

Secondary endpoints according to the published study protocol (Diabetes Care 2002):

- glycaemic control

- insulin sensitivity

- beta-cell function

- cardiovascular risk markers

- renal function

- patient reported outcomes (quality of life)

- resource utilization (direct health care costs will be assessed as the number of emergency room visits, number of unscheduled visits to the study physician's office, number of hospitalizations, and length of stay. Furthermore, indirect economic costs associated

with bed days (days when patients stay in bed for half a day or more) and restricted activity days (days when patients reduce their usual activities, such as housework

or shopping) will be evaluated)

- safety parameters (including hypoglycaemia)

AIM OF STUDY:

to evaluate the durability of glycemic control in 
Kahn 2006 (Continued)

patients receiving monotherapy with rosiglitazone, metformin or glyburide zhe therapeutic goal was a fasting plasma glucose

level below $140 \mathrm{mg} / \mathrm{dl}(7.8 \mathrm{mmol} / \mathrm{L})$.

\section{Risk of bias}

\begin{tabular}{lll} 
Item & Authors' judgement & Description \\
\hline Allocation concealment? & Yes & A - Adequate \\
\hline
\end{tabular}

\section{Ko 2006}

Methods

DURATION OF INTERVENTION:

one year

DURATION OF FOLLOW-UP:

one year

RUN-IN PERIOD:

none

LANGUAGE OF PUBLICATION:

English

Participants

WHO PARTCIPATED:

Chinese patients with type 2 diabetes and conventional oral antidiabetic drugs failure INCLUSION CRITERIA:

OAD failure was defined as persistent hyperglycaemia with haemoglobin AIc (HbA1c) $>=8.5 \%$ for 6 mo or longer despite continuous use of maximal doses of conventional OAD; maximum recommended doses of various OADs were given as follows: glibenclamide $20 \mathrm{mg} / \mathrm{d}$, gliclazide $320 \mathrm{mg} / \mathrm{d}$, glipizide $20 \mathrm{mg} / \mathrm{d}$, and metformin $3 \mathrm{~g} / \mathrm{d}$

EXCLUSION CRITERIA:

uncontrolled hypertension

with sitting blood pressure (BP) >200/110 mm Hg and/or a history of myocardial

infarction, cerebrovascular accident, or uncontrolled congestive heart failure during the previous 6 mo, or significant renal impairment (plasma creatinine concentration $>=150 \mathrm{mmol} / \mathrm{L}$ )

DIAGNOSTIC CRITERIA:

not stated

CO-MORBIDITIES:

not stated

CO-MEDICATIONS:

antihypertensive agents [no (\%)]:

I1: $31(55.3)$

C1: 14 (25.0)

lipid-lowering agents [no (\%)]:

I1: 5 (8.9)

C1: 2 (3.6)

Interventions

NUMBER OF STUDY CENTRES:

1

COUNTRY/ LOCATION: 


\begin{tabular}{|c|c|c|}
\hline & \multicolumn{2}{|c|}{$\begin{array}{l}\text { OAD - original OAD and other medications remained the same throughout the study } \\
\text { patients who fulfilled the inclusion criteria were referred to dietitians and diabetic nursing specialists for } \\
\text { reinforcement of their dietary habits, drug compliance, and an understanding of OAD failure; those with } \\
\text { HbAlc > } 8.5 \% \text { three months after reinforcement were included } \\
\text { TITRATION PERIOD: } \\
\text { oral rosiglitazone was started at } 2 \mathrm{mg} / \mathrm{d} \text {, insulin was begun at a dose of } 6 \text { units administered at night; the } \\
\text { insulin dose was titrated } 2 \text { to } 4 \mathrm{wk} \text { later by a diabetic nursing specialist with an increment of } 2 \text { to } 4 \text { units } \\
\text { according to tolerability of the insulin injection and fasting plasma glucose (PG) improvement } \\
\text { at } 12,24,36 \text {, and } 52 \mathrm{wk} \text {, all patients were seen for assessment of tolerability } \\
\text { and compliance with treatment, and for measurement of lipid, glycemic, and other biochemical indices; } \\
\text { insulin dosage was adjusted at each visit if this was deemed necessary, with the goal of achieving an } \\
\text { HbAlc concentration }<7.5 \% \text {; if the drug was tolerable to patients, rosiglitazone was also increased to the } \\
\text { maximum dose of } 8 \mathrm{mg} \\
\text { daily, with the goal of reducing HhA1c to }<7.5 \% \text { without the occurrence of significant } \\
\text { hypoglycemia }\end{array}$} \\
\hline Outcomes & \multicolumn{2}{|c|}{$\begin{array}{l}\text { PRIMARY OUTCOMES: } \\
\text { not stated (differences in HbA1c) } \\
\text { SECONDARY OUTCOMES: } \\
\text { (not stated) } \\
\text { lipids, BMI, FPG, blood pressure }\end{array}$} \\
\hline Notes & \multicolumn{2}{|c|}{$\begin{array}{l}\text { AIM OF STUDY: } \\
\text { to evaluate the efficacy and tolerability of rosiglitazone in patients with secondary oral anti-diabetic drug } \\
\text { failure and to directly compare rosiglitazone with bedtime insulin }\end{array}$} \\
\hline \multicolumn{3}{|l|}{ Risk of bias } \\
\hline Item & Authors' judgement & Description \\
\hline Allocation concealment? & Unclear & B - Unclear \\
\hline
\end{tabular}


Methods

Participants

Interventions
DURATION OF INTERVENTION:

26 weeks

DURATION OF FOLLOW-UP:

26 weeks

RUN-IN PERIOD:

4-week single blind placebo baseline period (instruction on a weight maintenance diet)

LANGUAGE OF PUBLICATION:

English

WHO PARTCIPATED:

patients with type 2 diabetes whose hyperglycemia was inadequately controlled by diet or an oral antihyperglycemic agent

INCLUSION CRITERIA:

36-81 years old, patients with a diagnosis of type 2 diabetes (as defined by the NDDG) if they had FPG between $7.8-16.7 \mathrm{mmol} / \mathrm{L}$, fasting plasma C-peptide level greater than $0.26 \mathrm{nmol} / \mathrm{L}$, and a body mass index (BMI) between $22-38 \mathrm{~kg} / \mathrm{m} 2$ at screening

EXCLUSION CRITERIA:

patients with angina or cardiac insufficiency NYHA class III or IV; renal impairment (serum creatinine > $159 \mathrm{mmol} / \mathrm{L}$ ), hepatic disease (alanine aminotransferase (ALT), aspartate aminotransferase (AST), alkaline phosphatase, or total bilirubin, $>2.5$ times the upper limit of the reference range); history of diabetic ketoacidosis, history of chronic insulin use, symptomatic diabetic neuropathy; a serious major illness that would compromise their participation; women of childbearing potential

DIAGNOSTIC CRITERIA:

NDDG 1979

CO-MORBIDITIES:

not stated

CO-MEDICATIONS:

not stated 
Lebovitz 2001 (Continued)

TITRATION PERIOD:

screening period of up to 14 days (during which patients discontinued all antidiabetic medications); 4week run-in; 26 weeks treatment period

PRIMARY OUTCOMES:
change in HbA1c from baseline to 26 weeks
SECONDARY OUTCOMES:
(not stated)
comparisons of rosiglitazone with placebo for changes from baseline to week 26 in FPG, C-peptide,
immunoreactive insulin, proinsulin, 32-33 split proinsulin, fructosamine, urinary albumin excretion as
determined by urinary albumin/creatinine ratio (ACR), and serum lipids; the proportions of patients who
had a reduction in HbAlc of more than 1 percentage point or a reduction in FPG of more than 1.67
mmol/L at week 26 compared with baseline; HOMA;
interim medical histories, reports of adverse events, and standard laboratory assessments (including clinical
chemistry, hematology, and urinalysis) were obtained at each visit; ECGs

Notes $\quad$ AIM OF STUDY:

to assess the efficacy and safety of rosiglitazone monotherapy in patients with type 2 diabetes whose hyperglycemia was inadequately controlled by diet or an oral antihyperglycemic agent

\section{Risk of bias}

\begin{tabular}{|c|c|c|}
\hline Item & Authors' judgement & Description \\
\hline Allocation concealment? & Unclear & B - Unclear \\
\hline
\end{tabular}

Ovalle 2004

\begin{tabular}{ll} 
Methods & DURATION OF INTERVENTION: \\
& 6 months \\
& DURATION OF FOLLOW-UP: \\
6 months & RUN-IN PERIOD: \\
& none \\
& LANGUAGE OF PUBLICATION: \\
& English \\
\hline Participants & WHO PARTCIPATED: \\
& patients with type 2 diabetes inadequately controlled on a maximized oral antihyperglycemic double \\
& regimen of glimepiride and metformin \\
& INCLUSION CRITERIA: \\
not stated & EXCLUSION CRITERIA: \\
& not stated \\
& DIAGNOSTIC CRITERIA: \\
not stated \\
CO-MORBIDITIES: \\
not stated \\
\end{tabular}




\begin{tabular}{|c|c|c|}
\hline & \multicolumn{2}{|l|}{$\begin{array}{l}\text { CO-MEDICATIONS: } \\
\text { not stated }\end{array}$} \\
\hline Interventions & \multicolumn{2}{|c|}{$\begin{array}{l}\text { NUMBER OF STUDY CENTRES: } \\
1 \\
\text { COUNTRY/ LOCATION: } \\
\text { USA } \\
\text { SETTING: } \\
\text { University of Alabama (Birmingham, Alabama, USA) } \\
\text { INTERVENTION (DOSE/DAY): } \\
\text { rosiglitazone } 8 \mathrm{mg}+\text { metformin/sulfonylurea } \\
\text { (administered once daily) } \\
\text { CONTROL (DOSE/DAY): } \\
\text { insulin injection of } 70130 \text { mixed human insulin (administered once daily before supper) + metformin/ } \\
\text { sulfonylurea } \\
\text { TREATMENT BEFORE STUDY: } \\
\text { maximized oral antihyperglycemic double regimen of glimepiride and metformin } \\
\text { TITRATION PERIOD: } \\
\text { the dose of rosiglitazone was fixed, whereas the } 70 / 30 \text { insulin was started at } 0.2 \text { units/kg and adjusted to } \\
\text { achieve a FPG level of }<=120 \mathrm{mgldl} \text { without occurrence of severe or frequent hypoglycaemia }\end{array}$} \\
\hline Outcomes & \multicolumn{2}{|c|}{$\begin{array}{l}\text { PRIMARY OUTCOMES: } \\
\text { not stated (pancreatic beta-cell function) } \\
\text { SECONDARY OUTCOMES: } \\
\text { (not stated) } \\
\text { fasting glucose, serum insulin, proinsulin levels, intravenous glucose tolerance tests, glucagon stimulation } \\
\text { test for C-peptide, HOMA }\end{array}$} \\
\hline Notes & \multicolumn{2}{|c|}{$\begin{array}{l}\text { AIM OF STUDY: } \\
\text { to confirm that TZDs improve pancreatic beta-cell function independent of the improvement in glycaemic } \\
\text { control }\end{array}$} \\
\hline \multicolumn{3}{|l|}{ Risk of bias } \\
\hline Item & Authors' judgement & Description \\
\hline Allocation concealment? & Unclear & B - Unclear \\
\hline
\end{tabular}




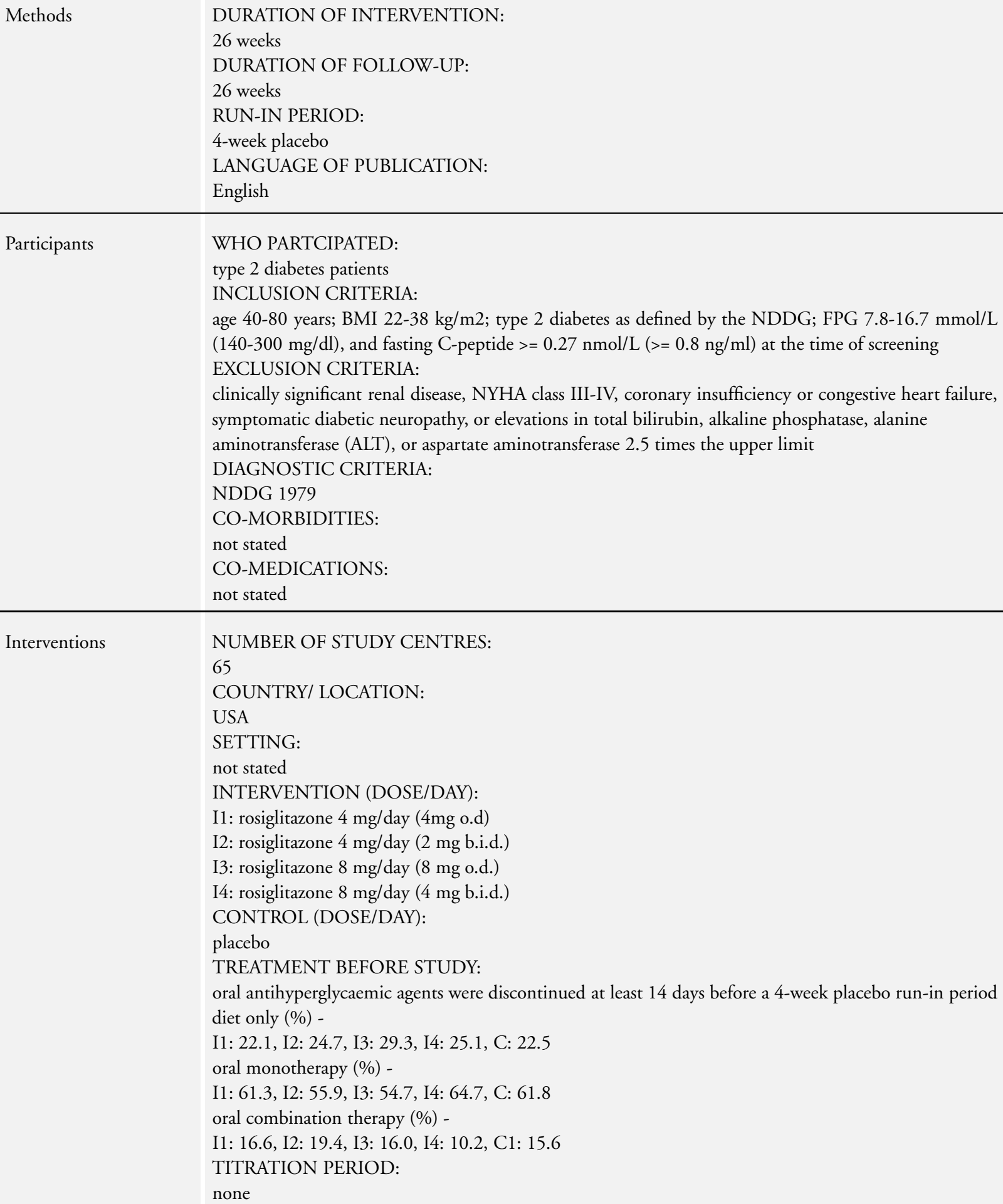

Interventions

\section{NUMBER OF STUDY CENTRES:}

65

COUNTRY/ LOCATION:

USA

SETTING:

not stated

INTERVENTION (DOSE/DAY):

I1: rosiglitazone $4 \mathrm{mg} /$ day ( $4 \mathrm{mg}$ o.d)

I2: rosiglitazone $4 \mathrm{mg} /$ day ( $2 \mathrm{mg}$ b.i.d.)

I3: rosiglitazone $8 \mathrm{mg} /$ day ( $8 \mathrm{mg}$ o.d.)

I4: rosiglitazone $8 \mathrm{mg} /$ day ( $4 \mathrm{mg}$ b.i.d.)

CONTROL (DOSE/DAY):

placebo

TREATMENT BEFORE STUDY:

oral antihyperglycaemic agents were discontinued at least 14 days before a 4-week placebo run-in period diet only (\%) -

I1: 22.1, I2: 24.7, I3: 29.3, I4: 25.1, C: 22.5

oral monotherapy (\%) -

I1: 61.3, I2: 55.9, I3: 54.7, I4: 64.7, C: 61.8

oral combination therapy (\%) -

I1: 16.6, I2: 19.4, I3: 16.0, I4: 10.2, C1: 15.6

TITRATION PERIOD:

none 
Phillips 2001 (Continued)

\begin{tabular}{|c|c|c|}
\hline Outcomes & \multicolumn{2}{|c|}{$\begin{array}{l}\text { PRIMARY OUTCOMES: } \\
\text { change in HbA1c from baseline (end of the 4-week placebo run-in period) after } 26 \text { weeks of treatment } \\
\text { SECONDARY OUTCOMES: } \\
\text { the change from baseline after } 26 \text { weeks of treatment in FPG, immunoreactive insulin, C-peptide, lipid } \\
\text { levels } \\
\text { Clinical chemistry, hematology, liver enzymes, and urinalysis; HOMA }\end{array}$} \\
\hline Notes & \multicolumn{2}{|c|}{$\begin{array}{l}\text { AIM OF STUDY: } \\
\text { to examine the efficacy of rosiglitazone in reducing HbA1c and to evaluate the } \\
\text { therapeutic equivalence of once-daily and twice-daily dosing regimens }\end{array}$} \\
\hline \multicolumn{3}{|l|}{ Risk of bias } \\
\hline Item & Authors' judgement & Description \\
\hline Allocation concealment? & Unclear & B - Unclear \\
\hline
\end{tabular}

Raskin 2004

Methods

DURATION OF INTERVENTION:

24 weeks

DURATION OF FOLLOW-UP:

24 weeks

RUN-IN PERIOD:

a screening visit was followed by a 2-week washout period (previous diabetes medication discontinued)

LANGUAGE OF PUBLICATION:

English

Participants

WHO PARTCIPATED:

type 2 diabetic patients who had shown treatment failure using sulphonylurea monotherapy or metformin monotherapy

INCLUSION CRITERIA:

type 2 diabetes for at least 12 months, with $\mathrm{HbA1}$ c values $>7.0 \%$ and $<=12 \%$ during previous monotherapy with sulphonylurea or metformin (at $50 \%$ or more of the maximal recommended dosages) for at least 3 months

EXCLUSION CRITERIA:

if being treated within the previous 3 months with any of the following agents: insulin, repaglinide, thiazolidinediones, alpha-glucosidase inhibitors, or combination therapy with antidiabetic medications DIAGNOSTIC CRITERIA:

not stated

CO-MORBIDITIES:

not stated

CO-MEDICATIONS:

not stated

Interventions

NUMBER OF STUDY CENTRES:

not stated (multicentre)

COUNTRY/ LOCATION: 
USA

SETTING:

not stated

INTERVENTION (DOSE/DAY):

I1: rosiglitazone $8.0 \mathrm{mg} /$ day (mean final dose)

I2: rosiglitazone $6.0 \mathrm{mg} /$ day (mean final dose) + repaglinide $4.0 \mathrm{mg} /$ day (mean final dose)

CONTROL (DOSE/DAY):

repaglinide $12 \mathrm{mg} /$ day (mean final dose)

TREATMENT BEFORE STUDY:

previous monotherapy with sulphonylurea or metformin (at $50 \%$ or more of the maximal recommended dosages) for at least 3 months:

previous SU/metformin (n/n/tot) -

I1: 30/32/62, I2: 81/46/127 ,

C: $40 / 23 / 63$

TITRATION PERIOD:

12-week dose-adjustment period:

repaglinide monotherapy

was initiated at $0.5 \mathrm{mg}$ per meal if $\mathrm{HbA} 1 \mathrm{c}$ levels were $<=8 \%$, and at $1 \mathrm{mg}$ per meal for all other patients;

the initial dosage of rosiglitazone monotherapy was $2 \mathrm{mg}$ b.i.d.;

repaglinide/rosiglitazone combination therapy was initiated at $0.5 \mathrm{mg}$ or $1 \mathrm{mg}$ repaglinide per meal (adjusted according to HbA1c as above), plus $2 \mathrm{mg}$ rosiglitazone b.i.d

all patients in groups treated with repaglinide (monotherapy or combination) could have dosage adjusted up to a maximal dose of $4 \mathrm{mg}$ per meal; the rosiglitazone dosage could be doubled in monotherapy or combination therapy groups at week 12 , up to a maximum dose not to exceed $4 \mathrm{mg}$ b.i.d.; the doseadjustment period was followed by 12 additional

weeks of maintenance therapy

Outcomes $\quad$ PRIMARY OUTCOMES:

change in HbA1c values from baseline to the end of study treatment

SECONDARY OUTCOMES:

changes in FPG values;

alanine aminotransferase (ALT); lipids; adverse events and reports of hypoglycemic episodes

Notes
to investigate the therapeutic effects
of repaglinide combination therapy with rosiglitazone; the efficacy, safety, and tolerability of the combi-
nation were compared with those of monotherapy with either agent alone, in patients who had shown
treatment failure using sulphonylurea monotherapy or metformin monotherapy

Risk of bias

\begin{tabular}{lll}
\hline Item & Authors' judgement & Description \\
\hline Allocation concealment? & Unclear & B - Unclear \\
\hline
\end{tabular}

Rosiglitazone for type 2 diabetes mellitus (Review) 
Methods

DURATION OF INTERVENTION:

24 weeks

DURATION OF FOLLOW-UP:

24 weeks

RUN-IN PERIOD:

during the screening/titration phase, patients not on the maximum metformin dose were titrated to 2000

$\mathrm{mg}$ /day; patients on $1000 \mathrm{mg} /$ day increased their dose to $1500 \mathrm{mg} /$ day immediately and to $2000 \mathrm{mg} /$ day

1 week later (or maximum tolerated dose), followed by a 2-week stabilization period; patients on 1500

$\mathrm{mg} /$ day increased their dose to $2000 \mathrm{mg}$ /day immediately followed by a 2-week stabilization period

LANGUAGE OF PUBLICATION:

English

Participants

WHO PARTCIPATED:

insulin-naive patients with type 2 diabetes inadequately controlled on dual oral therapy with sulfonylurea plus metformin

INCLUSION CRITERIA:

participants $>=18$ years of age with type 2 diabetes (HbA1c $>=7.5$ and $<=11 \%$ ) and a BMI of $>25$; continuous oral hypoglycemic treatment using stable daily doses of $>=50 \%$ of the maximally labeled dose of a sulfonylurea and at least $1000 \mathrm{mg}$ metformin was required for $>=3$ months before the screening

visit

\section{EXCLUSION CRITERIA:}

stroke, myocardial infarction, angina pectoris, coronary artery bypass graft, or percutaneous transluminal coronary angioplasty within the previous 12 months; history of congestive heart failure; treatment with nonselective beta-blockers; hypoglycemia unawareness; impaired renal function; active liver disease; substance or alcohol abuse; malignancy; planned radiological examinations requiring administration of contrasting agents

DIAGNOSTIC CRITERIA:

HbAlc $>=7.5$ and $<=11 \%$

CO-MORBIDITIES:

not stated

CO-MEDICATIONS:

not stated

NUMBER OF STUDY CENTRES:

42

COUNTRY/ LOCATION:

USA

SETTING:

not stated

INTERVENTION (DOSE/DAY):

$>=50 \%$ of maximal-dose sulfonylurea and metformin + rosiglitazone $4 \mathrm{mg} /$ day (mean daily dose rosiglitazone

was $7.1+-1.7 \mathrm{mg})$

CONTROL (DOSE/DAY):

$>=50 \%$ of maximal-dose sulfonylurea and metformin + insulin glargine 10 units/day (mean daily dose of insulin

glargine was $38.5+-26.5 \mathrm{IU})$

TREATMENT BEFORE STUDY:

slfonylurea and metformin doses remained unchanged during the treatment phase of the study TITRATION PERIOD: 


\begin{tabular}{|c|c|}
\hline & $\begin{array}{l}\text { (see run-in phase) } \\
\text { all patients randomized to insulin glargine received a single daily subcutaneous injection at bedtime at } \\
\text { a starting dose of } 10 \mathrm{IU} / \text { day for } 7 \text { days, the dose was titrated weekly according to self-monitored FPG, } \\
\text { supervised centrally to ensure compliance, to meet target FPG }<100-120 \mathrm{mg} / \mathrm{dl}(<5.5-6.7 \mathrm{mmol} / \mathrm{L}) \\
\text { all patients randomized to treatment with rosiglitazone received a starting oral dose of } 4 \mathrm{mg} \text { once daily } \\
\text { for } 6 \text { weeks; if the FPG value was }>100 \mathrm{mg} / \mathrm{dl}(>5.5 \mathrm{mmol} / \mathrm{L}) \text { after } 6 \text { weeks, rosiglitazone was increased } \\
\text { to a maximum of } 8 \mathrm{mg} / \text { day }\end{array}$ \\
\hline Outcomes & $\begin{array}{l}\text { PRIMARY OUTCOMES: } \\
\text { not stated (HbA1c differences between therapies) } \\
\text { SECONDARY OUTCOMES: } \\
\text { (not stated) } \\
\text { assessment of hypoglycaemia profile; changes in FPG, body weight, and serum lipids; proportion of } \\
\text { patients achieving HbAA1C <= } 7 \% \text {; cost of therapy } \\
\text { safety was assessed in the intent to treat (ITT) population through adverse events, hypoglycaemia, body } \\
\text { weight, physical examinations, vital signs, standard hematology,and blood chemistry } \\
\text { a physical examination to identify signs of peripheral oedema was performed at baseline and final visit or } \\
\text { at patient discontinuation } \\
\text { Cost analysis: } \\
\text { The economic costs of glyceemic control were compared by combining selected measures of resource use } \\
\text { with unit-cost estimates. Resource measures included study medication, other antihyperglycaemic agents, } \\
\text { syringes for insulin glargine, } \\
\text { glucose testing supplies for both groups, and recommended liver function tests for the rosiglitazone group. } \\
\text { Resource use was } \\
\text { based on trial data over the } 24 \text {-week period. Costs of medications, insulin syringes, test strips, and lancets } \\
\text { were } \\
\text { estimated using average wholesale prices expressed in } 2002 \text { U.S. dollars and were based on the numbers } \\
\text { actually dispensed. The cost of hepatic function panels was estimated using fee schedules under Medi- } \\
\text { care's Resource-Based Relative Value Scale. Economic costs were summarized using means and } 95 \% \text { CIs } \\
\text { and calculated through techniques of bootstrapping. Results were not adjusted for differences between } \\
\text { treatment }\end{array}$ \\
\hline Notes & $\begin{array}{l}\text { AIM OF STUDY: } \\
\text { to evaluate the efficacy and safety of insulin glargine or rosiglitazone as add-on therapy in patients with type } \\
2 \text { diabetes with chronic hyperglycemic control despite maximized combination therapy with metformin } \\
\text { plus a sulfonylurea }\end{array}$ \\
\hline \multicolumn{2}{|l|}{ Risk of bias } \\
\hline Item & Authors' judgement \\
\hline Allocation concealment? & Unclear \\
\hline
\end{tabular}


Methods

DURATION OF INTERVENTION:

24 weeks

DURATION OF FOLLOW-UP:

24 weeks

RUN-IN PERIOD:

none

LANGUAGE OF PUBLICATION:

English

Participants

WHO PARTCIPATED:

type 2 diabetes patients with suboptimally controlled diabetes mellitus

INCLUSION CRITERIA:

between 21 and 80 years of age, with a glycosylated hemoglobin level above $7.0 \%$ during treatment with either diet modification or sulfonylurea monotherapy

EXCLUSION CRITERIA:

known inflammatory diseases (including inflammatory bowel disease, vasculitis, and rheumatologic

disease), insulin use, corticosteroid use, an infection within 1 month of enrollment, glomerular filtration rate $<60 \mathrm{ml} / \mathrm{min}$,

pregnancy, known history of myocardial infarction or congestive heart failure, secondary diabetes (including Cushing's syndrome and acromegaly), hypersensitivity to metformin or rosiglitazone, or a history of carotid endarterectomy DIAGNOSTIC CRITERIA:

not stated

CO-MORBIDITIES:

known cardiovascular disease [no (\%)]

I1: $2(4.4 \%)$

C1: $3(6.4 \%)$

CO-MEDICATIONS:

statin use [no (\%)]:

I1: $24(53.3 \%)$

C1: 23 (48.9\%)

aspirin use [no (\%)] :

I1: $21(46.7 \%)$

C1: $28(59.6 \%)$

beta-blocker use [no (\%)]:

I1: $8(17.8 \%)$

C1: 7 (14.9\%)

calcium-channel

blocker use [no (\%)]:

I1: $6(13.3 \%)$

C1: $13(27.7 \%)$

angiotensin receptor

blocker use [no (\%)]:

I1: $2(4.4 \%)$

C1: $0(0 \%)$

ACE inhibitor use [no (\%)]:

I1: $23(51.1 \%)$

C1: 30 (63.8\%)

sulfonylurea use [no (\%)]:

I1: $34(75.6 \%)$

C1: $34(72.3 \%)$ 
Stocker 2007 (Continued)

\begin{tabular}{|c|c|c|}
\hline Interventions & \multicolumn{2}{|c|}{$\begin{array}{l}\text { NUMBER OF STUDY CENTRES: } \\
1 \\
\text { COUNTRY/ LOCATION: } \\
\text { USA } \\
\text { SETTING: } \\
\text { Diabetes Institute of theWalter Reed Army Medical Center, Washington DC, USA } \\
\text { INTERVENTION (DOSE/DAY): } \\
\text { rosiglitazone } 4 \text { mg o.d. } \\
\text { CONTROL (DOSE/DAY): } \\
\text { metformin } 850 \text { mg b.i.d. } \\
\text { TREATMENT BEFORE STUDY: } \\
\text { diet modification or sulfonylurea monotherapy } \\
\text { TITRATION PERIOD: } \\
\text { other concurrent therapies (sulfonylurea, antihypertensive, or } \\
\text { statin medications) were continued at stable doses during the study } \\
\text { nutrition counseling and diabetes education was offered to all participants at enrollment, in addition to } \\
\text { their study medication }\end{array}$} \\
\hline Outcomes & \multicolumn{2}{|c|}{$\begin{array}{l}\text { PRIMARY OUTCOMES: } \\
\text { change in C-reactive protein (CRP) levels after } 24 \text { weeks between the metformin and rosiglitazone treat- } \\
\text { ment groups } \\
\text { SECONDARY OUTCOMES: } \\
\text { the predefined secondary } \\
\text { end point was the change in mean and maximal CIMT of the common carotid artery } \\
\text { further outcomes: } \\
\text { FPG, HbA1c, lipids, weight, carotid intima media thickness (CIMT) }\end{array}$} \\
\hline Notes & \multicolumn{2}{|c|}{$\begin{array}{l}\text { AIM OF STUDY: } \\
\text { to compare the effects of rosiglitazone and metformin on C-reactive } \\
\text { protein }(\mathrm{CRP}) \text { and carotid intima media thickness (CIMT) }\end{array}$} \\
\hline \multicolumn{3}{|l|}{ Risk of bias } \\
\hline Item & Authors' judgement & Description \\
\hline Allocation concealment? & Unclear & B - Unclear \\
\hline
\end{tabular}


Methods

DURATION OF INTERVENTION:

52 weeks

DURATION OF FOLLOW-UP:

52 weeks

RUN-IN PERIOD:

4-week placebo run-in period (single-blind, with diet maintenance)

LANGUAGE OF PUBLICATION:

English

Participants

WHO PARTCIPATED:

type 2 diabetic patients

INCLUSION CRITERIA:

patients aged 40-80 years were eligible if they met the NDDG definition forvtype 2 diabetes, with endogenous insulin production (fasting C-peptide concentration $>=0.8 \mathrm{ng} / \mathrm{ml}$ at screening); female patients had to be postmenopausal, surgically sterile, or currently using hormonal contraceptives or intrauterine devices

\section{EXCLUSION CRITERIA:}

clinically significant renal disease (serum creatinine level $>=1.8 \mathrm{mg} / \mathrm{dl}$ ) or hepatic disease (alanine transaminase, aspartate transaminase, total bilirubin, or alkaline phosphatase levels $>2.5$ times the upper limit of the normal laboratory range); previous treatment for myocardial infarction; NYHA class III-IV, coronary insufficiency or congestive heart failure; previous or existing treatment with ACE inhibitors, angiotensin II receptor antagonists, beta-blockers, or calcium-channel blockers; echocardiographic evidence of marked left ventricular hypertrophy at baseline; or uncontrolled BP $(>160 />100 \mathrm{mmHg})$; whereas patients taking diuretics and lipid-lowering agents were not excluded from the study, doses were not to be changed during the study unless deemed medically appropriate

DIAGNOSTIC CRITERIA:

NDDG

CO-MORBIDITIES:

concomitant hypertension (\%) - I: 7.7, C: 7.0

CO-MEDICATIONS:

not stated

Interventions

NUMBER OF STUDY CENTRES:

19

COUNTRY/ LOCATION:

USA

SETTING:

not stated

INTERVENTION (DOSE/DAY):

rosiglitazone $8 \mathrm{mg}$ (4 $\mathrm{mg}$ b.i.d.)

CONTROL (DOSE/DAY):

glyburide

TREATMENT BEFORE STUDY:

previous antidiabetic treatment :

diet only (\%) - I: 21.2 , C: 18.2

single agent (\%) - I: 70.2, C: 69.7

combination therapy (\%): I: 8.7 , C: 12.1

2-week screening period; previous oral antidiabetic medications were discontinued at the screening visit, at which time all patients received placebo and dietary instruction; patients were reevaluated at 2-week intervals during the placebo run-in period; those with FPG $>=140 \mathrm{mg} / \mathrm{dl}$ but $<=300 \mathrm{mg} / \mathrm{dl}$ at visits 2 
Sutton 2002 (Continued)

and 3 were eligible to enter the treatment period

TITRATION PERIOD:

glyburide (q.i.d. or b.i.d.) was titrated at the discretion of the investigator to optimal glycemic effect over the first 8 weeks and then held constant for the duration of the study period; the dose of glyburide did not exceed $20 \mathrm{mg} /$ day

Outcomes $\quad$ PRIMARY OUTCOMES

change from baseline in left ventricular mass index, at weeks 28 and 52, with the between-groups difference as the primary comparison of interest

SECONDARY OUTCOMES:

(not stated)

changes from baseline to weeks 28 and 52 in left ventricular end-diastolic volume and ejection fraction as well as mean values of BP, heart rate, arterial pressure, and pulse pressure (from 24-h ambulatory monitoring); glycemic control (HbA1c and FPG); serum lipids fasting clinical laboratory tests, including chemistry, haematology, and urinalysis

clinical interpretation of safety was based on review of ECG and echocardiographic data, adverse event reports, and laboratory values

Notes

AIM OF STUDY:

to assess the effect of long-term rosiglitazone treatment on cardiac structure/function and glycaemic control in patients with type 2 diabetes compared with glyburide

Risk of bias

\begin{tabular}{lll}
\hline Item & Authors' judgement & Description \\
\hline Allocation concealment? & Unclear & B - Unclear \\
\hline
\end{tabular}

Yang 2002

\begin{tabular}{|c|c|}
\hline Methods & $\begin{array}{l}\text { DURATION OF INTERVENTION: } \\
6 \text { months } \\
\text { DURATION OF FOLLOW-UP: } \\
6 \text { months } \\
\text { RUN-IN PERIOD: } \\
\text { single-blind placebo/sulfonylurea run-in period for } 4 \text { weeks to establish baseline characteristics } \\
\text { LANGUAGE OF PUBLICATION: } \\
\text { English }\end{array}$ \\
\hline Participants & $\begin{array}{l}\text { WHO PARTCIPATED: } \\
\text { type } 2 \text { diabetic patients on concurrent sulphonylurea therapy } \\
\text { INCLUSION CRITERIA: } \\
\text { aged } 30-80 \text { years; type } 2 \text { diabetic patients according to diagnostic criteria of the WHO, FPG } 7-15 \mathrm{mmol} / \\
\mathrm{L} \text { and HbA1c > } 7.5 \% \text {; who had been stable on sulfonylurea therapy for at least } 2 \text { months before the } \\
\text { screening } \\
\text { EXCLUSION CRITERIA: } \\
\text { other severe medical problems and severe microvascular complications requiring immediate medical at- } \\
\text { tention }\end{array}$ \\
\hline
\end{tabular}




\begin{tabular}{|c|c|c|}
\hline & \multicolumn{2}{|c|}{$\begin{array}{l}\text { DIAGNOSTIC CRITERIA: } \\
\text { WHO } \\
\text { CO-MORBIDITIES: } \\
\text { not stated } \\
\text { CO-MEDICATIONS: } \\
\text { not stated }\end{array}$} \\
\hline Interventions & \multicolumn{2}{|c|}{$\begin{array}{l}\text { NUMBER OF STUDY CENTRES: } \\
\text { not stated (1) } \\
\text { COUNTRY/ LOCATION: } \\
\text { Taiwan } \\
\text { SETTING: } \\
\text { not stated } \\
\text { INTERVENTION (DOSE/DAY): } \\
\text { rosiglitazone } 4 \mathrm{mg} / \text { day }(2 \mathrm{mg} \text { b.i.d.) + sulfonylureas } \\
\text { CONTROL (DOSE/DAY): } \\
\text { placebo (twice daily) + sulfonylureas } \\
\text { TREATMENT BEFORE STUDY: } \\
\text { who had been stable on sulfonylurea therapy for at least } 2 \text { months before the screening } \\
\text { TITRATION PERIOD: }\end{array}$} \\
\hline Outcomes & \multicolumn{2}{|c|}{$\begin{array}{l}\text { PRIMARY OUTCOMES: } \\
\text { not stated (plasma levels of adiponectin) } \\
\text { SECONDARY OUTCOMES: } \\
\text { (not stated) } \\
\text { HbA1c; body weight, height, blood pressure, heart rate, plasma glucose, total cholesterol, triglycerides, } \\
\text { HOMA }\end{array}$} \\
\hline Notes & \multicolumn{2}{|c|}{$\begin{array}{l}\text { AIM OF STUDY: } \\
\text { to assess whether adiponectin levels might increase in type } 2 \text { diabetes patients treated with rosiglitazone }\end{array}$} \\
\hline \multicolumn{3}{|l|}{ Risk of bias } \\
\hline Item & Authors' judgement & Description \\
\hline Allocation concealment? & Unclear & B - Unclear \\
\hline
\end{tabular}

$\mathrm{ACE}=$ angiotensin converting enzyme; $\mathrm{ADA}=$ American Diabetes Association; ALT = alanine aminotransferase; AST = aspartate aminotransferase; AT II = angiotensin II; b.(i.)d. = bis in die, twice daily; BMI = body mass index $(\mathrm{kg} / \mathrm{m} 2)$; BP = blood pressure; $\mathrm{C}=$ control group; $\mathrm{CRP}=\mathrm{C}$-reactive protein; $\mathrm{CVD}=$ cardiovascular disease; $\mathrm{ECG}=$ electrocardiogram; $\mathrm{FCBG}=$ fasting capillary blood glucose; FPG = fasting plasma glucose; HbA1c = glycosylated haemoglobin A1c; HOMA = homeostasis model assessment (of insulin sensitvity); I = intervention group; ITT = intention-to-treat; NDDG = National Diabetes Data Group; NYHA = New York Heart Association; $\mathrm{OAD}=$ oral antidiabetic drug: $\mathrm{OAM}=$ oral antidiabetic medication; o.d. = once daily; PPAR = peroxisome proliferator activated receptor; PPG = postprandial glucose; q.d. = quaque die, once a day; $\mathrm{SU}=$ sulfonylureas; t.i.d. = ter in die, three times daily; TZD = thiazolidinediones ("glitazones”); U = Unit; WHO = World Health Organization 
Characteristics of excluded studies [ordered by study ID]

\begin{tabular}{|c|c|}
\hline Study & Reason for exclusion \\
\hline Bailey 2005 & treatment regimens not comparable (rosiglitazone plus metformin versus metformin) \\
\hline Baksi 2004 & treatment regimens not comparable (rosiglitazone plus gliclazide versus gliclazide) \\
\hline Barnett 2003 & treatment regimens not comparable (rosiglitazone plus sulfonylureas versus sulfonylureas plus placebo) \\
\hline Dailey 2004 & $\begin{array}{l}\text { treatment regimens not comparable (rosiglitazone plus glyburide/metformin versus placebo plus glyburide/ } \\
\text { metformin) }\end{array}$ \\
\hline Fonseca 2000 & treatment regimens not comparable (rosiglitazone plus metformin versus placebo plus metformin) \\
\hline Fonseca 2003 & treatment regimens not comparable (rosiglitazone plus placebo versus rosiglitazone plus nateglinide) \\
\hline Gomez-Perez 2002 & treatment regimens not comparable (rosiglitazone plus metformin versus placebo plus metformin) \\
\hline Hubacek 2004 & rosiglitazone treatment less than 24 weeks \\
\hline Kerenyi 2004 & treatment regimens not comparable (rosiglitazone plus glibenclamide versus glibenclamide) \\
\hline McCluskey 2004 & treatment regimens not comparable (rosiglitazone plus glimepiride versus glimepiride) \\
\hline Negro 2005 & treatment regimens not comparable (rosiglitazone plus metformin versus placebo plus metformin) \\
\hline Raskin 2001 & treatment regimens not comparable (rosiglitazone plus insulin versus placebo plus insulin) \\
\hline Reynolds 2002 & $\begin{array}{l}\text { treatment regimens not comparable (rosiglitazone plus insulin plus life-style modification versus placebo plus } \\
\text { insulin plus life-style modification) }\end{array}$ \\
\hline Rosenstock 2006a & treatment regimens not comparable (rosiglitazone plus glipizide versus placebo plus glipizide) \\
\hline Tan 2005 a & rosiglitazone treatment less than 24 weeks \\
\hline Tan 2005b & rosiglitazone treatment less than 24 weeks \\
\hline Vongthavaravat 2002 & treatment regimens not comparable (rosiglitazone plus sulfonylureas versus sulfonylureas alone) \\
\hline Wang 2005 & treatment regimens not comparable (rosiglitazone versus "control" without treatment) \\
\hline Weissman 2005 & treatment regimens not comparable (rosiglitazone plus metformin versus metformin) \\
\hline Wolffenbuttel 2000 & treatment regimens not comparable (rosiglitazone plus sulfonylureas versus sulfonylureas plus placebo) \\
\hline Wong 2005 & treatment regimens not comparable (rosiglitazone plus insulin versus insulin) \\
\hline
\end{tabular}

Rosiglitazone for type 2 diabetes mellitus (Review) 


\section{Characteristics of ongoing studies [ordered by study ID]}

\section{RECORD}

\begin{tabular}{l|l}
\hline Trial name or title & Rosiglitazone Evaluated for Cardiac Outcomes and Regulation of Glycaemia in Diabetes (RECORD) \\
\hline Methods & $\begin{array}{l}\text { RECORD is a 6-year, randomised, open-label study in } \\
\text { type } 2 \text { diabetic patients with inadequate blood glucose control (HbA1c 7.1-9.0\%) on metformin or sulpho- } \\
\text { nylurea alone }\end{array}$ \\
\hline Interventions & $\begin{array}{l}\text { after a 4-week run-in, participants are randomised by current treatment stratum to } \\
\text { add-on rosiglitazone, metformin or sulphonylurea, with } \\
\text { dose titration to a target HbA1c of <-7.0\%; if confirmed HbA1c rises to > }>8.5 \%, \text { either a third glucose- } \\
\text { lowering drug } \\
\text { is added (rosiglitazone-treated group) or insulin is started } \\
\text { (non-rosiglitazone group); the same criterion for failure of triple oral drug therapy in the rosiglitazone-treated } \\
\text { group is used for starting insulin in this group }\end{array}$ \\
\hline
\end{tabular}

Outcomes the primary endpoint is the time to first cardiovascular hospitalisation or death, blindly adjudicated by a central endpoints committee; the study aim is to evaluate non-inferiority of the rosiglitazone group versus the non-rosiglitazone group with respect to cardiovascular outcomes; safety, tolerability and study conduct are monitored by an independent board

Starting date recruitment began in April 2001 and was completed in April 2003

\section{Contact information P. D. Home}

School of Clinical Medical Sciences-Diabetes,

University of Newcastle upon Tyne,

Medical School, Framlington Place,

Newcastle upon Tyne,

NE2 4HH, UK

E-mail: philip.home@newcastle.ac.uk

Tel.: +44-191-2227019

Fax: +44-191-2220723 
DATA AND ANALYSES

Comparison 1. Adverse events

\begin{tabular}{lcccc} 
Outcome or subgroup title & $\begin{array}{c}\text { No. of } \\
\text { studies }\end{array}$ & $\begin{array}{c}\text { No. of } \\
\text { participants }\end{array}$ & Statistical method & Effect size \\
\hline $\begin{array}{l}\text { 1 No. of patients experiencing } \\
\text { oedema }\end{array}$ & 9 & 4739 & Odds Ratio (M-H, Fixed, 95\% CI) & $2.27[1.83,2.81]$ \\
\hline
\end{tabular}

Analysis I.I. Comparison I Adverse events, Outcome I No. of patients experiencing oedema.

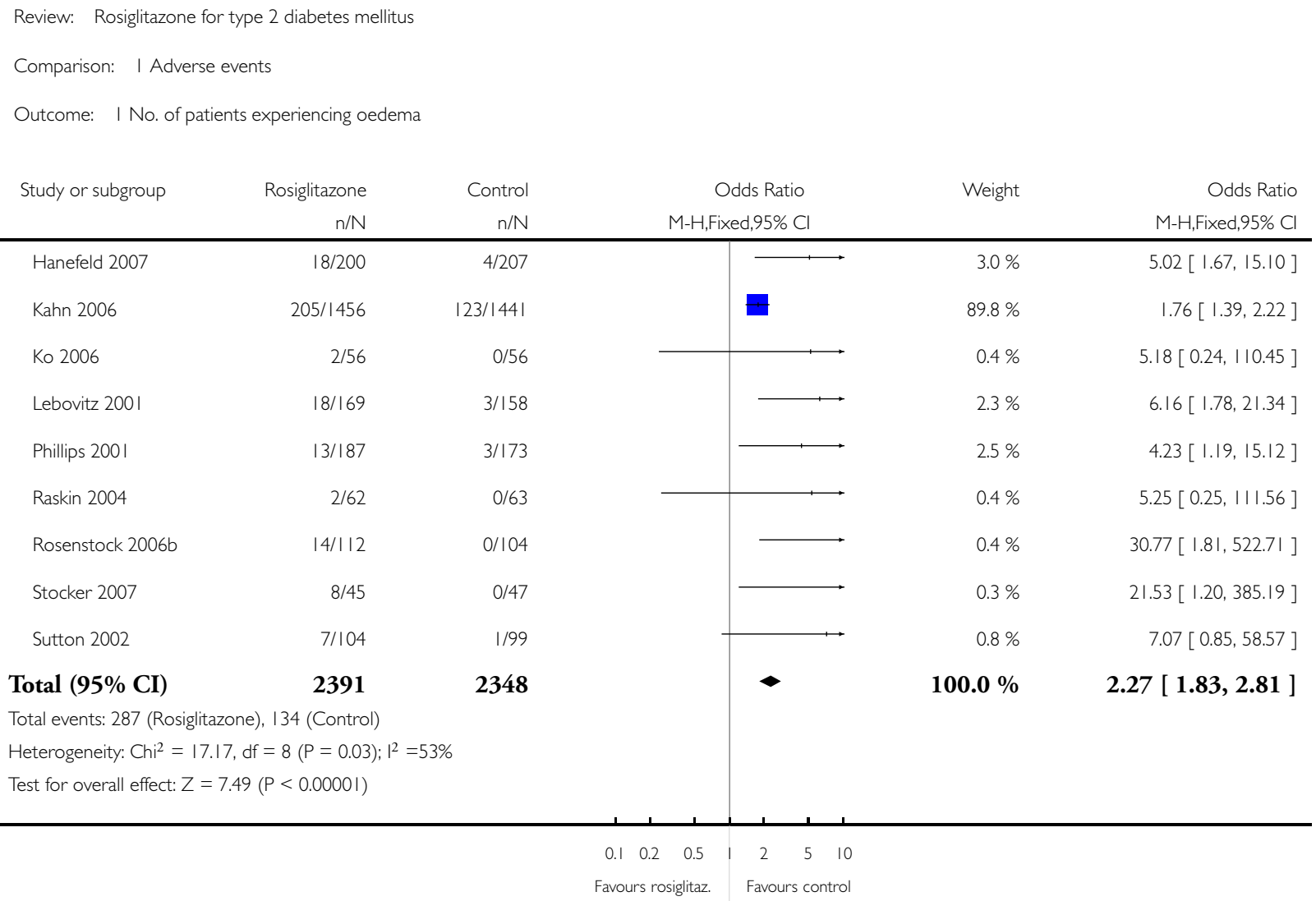


AP PENDICES

\section{Appendix I. Search strategy}

\section{Search terms}

Unless otherwise stated, search terms are free text terms; MesH = Medical subject heading (Medline medical index term); exp = exploded $\mathrm{MeSH}$; the dollar sign (\$) stands for any character(s); the question mark (?) = to substitute for one or no characters; tw = text word; $\mathrm{pt}=$ publication type; $\mathrm{sh}=\mathrm{MeSH}$; adj = adjacent.

1. $\exp$ THIAZOLIDINEDIONES/

2. (rosiglitazon\$ or thiazolidinedion\$).tw.

3. 1 or 2

4. randomized controlled trial.pt.

5. controlled clinical trial.pt.

6. randomized controlled trials.sh.

7. random allocation.sh.

8. double-blind method.sh.

9. single-blind method.sh.

10. ((singl\$ or doubl\$ or tripl\$ or trebl\$) adj6 (mask\$ or blind\$)).tw.

11. (random $\$$ adj25 (trial $\$$ or stud $\$$ or investigat $\$$ or cross over or crossover)).tw.

12.4 or 5 or 6 or 7 or 8 or 9 or 10 or 11

13. exp meta-analysis/

14. exp Review Literature/

15. meta-analysis.pt.

16. systematic review\$.tw.

17. search\$.tw.

18. medline.tw.

19. cochrane database of systematic reviews.jn.

20. 13 or 14 or 15 or 16 or 17 or 18 or 19

21. letter.pt.

22. comment.pt.

23. editorial.pt.

24. historical-article.pt.

25. 21 or 22 or 23 or 24

26. 20 not 25

27. exp Technology Assessment, Biomedical/

28. HTA.tw.

29. (health technology adj6 assessment\$).tw.

30. (biomedical adj6 technology assessment\$).tw.

31.27 or 28 or 29 or 30

Rosiglitazone for type 2 diabetes mellitus (Review)

Copyright @ 2009 The Cochrane Collaboration. Published by John Wiley \& Sons, Ltd. 
32. exp diabetes mellitus/

33. diabet\$.tw.

34. IDDM.tw.

35. NIDDM.tw.

36. MODY.tw.

37. (late onset adj diabet\$).tw.

38. (maturity onset adj diabet\$).tw.

39. (non insulin\$ depend\$ or noninsulin\$ depend\$ or non insulin?depend\$ or noninsulin?depend\$).tw.

40. ((typ\$ 1 or typ\$2) adj6 diabet\$).tw.

41. ((typ\$ I or typ\$ II) adj6 diabet\$).tw.

42. (insulin $\$$ depend $\$$ or insulin?depend\$).tw.

43. (T1DM or T2DM).tw.

44.32 or 33 or 34 or 35 or 36 or 37 or 38 or 39 or 40 or 41 or 42 or 43

45. 3 and 12 and 44

46. 3 and 26 and 44

47. 3 and 31 and 44

48. 45 or 46 or 47

Appendix 2. Baseline characteristics (I)

\begin{tabular}{|c|c|c|c|}
\hline Characteristic & Derosa 2004 & Derosa 2006a & Derosa 2006b \\
\hline & $\begin{array}{l}\text { I1: rosiglitazone } 4 \mathrm{mg} \mathrm{+} \\
\text { glimepiride } 4 \mathrm{mg} \\
\mathrm{C} 1 \text { : pioglitazone } 15 \mathrm{mg}+ \\
\text { glimepiride } 4 \mathrm{mg}\end{array}$ & $\begin{array}{l}\mathrm{I} 1 \text { : rosiglitazone } 4 \mathrm{mg}+\text { met- } \\
\text { formin } 3000 \mathrm{mg} \\
\mathrm{C} 1 \text { : pioglitazone } 15 \mathrm{mg}+\text { met- } \\
\text { formin } 3000 \mathrm{mg}\end{array}$ & $\begin{array}{l}\text { I1: rosiglitazone } 4 \mathrm{mg}+\text { met- } \\
\text { formin } 1500 \mathrm{mg} \\
\mathrm{C} 1 \text { : glimepiride } 2 \mathrm{mg}+\text { met- } \\
\text { formin } 1500 \mathrm{mg}\end{array}$ \\
\hline Sex $[\%]$ & $\begin{array}{l}\text { I1: female 48; male } 52 \\
\text { C1: female 53; male } 447\end{array}$ & $\begin{array}{l}\text { I1: female } 48 \text {; male } 52 \\
\text { C1: female } 50 \text {; male } 50\end{array}$ & $\begin{array}{l}\text { I1: female } 48 \text {; male } 52 \\
\text { C1: female } 51 \text {; male } 49\end{array}$ \\
\hline Age [years], mean (SD) & $\begin{array}{l}\text { I1: } 54(5) \\
\text { C1: } 53(6)\end{array}$ & $\begin{array}{l}\text { I1: } 56(4) \\
\text { C1: } 55(5)\end{array}$ & $\begin{array}{l}\text { I1: } 54(4) \\
\text { C1: } 52(5)\end{array}$ \\
\hline Ethnic groups [\%] & $\begin{array}{l}\text { I1: white } 100 \\
\text { C1: white } 100\end{array}$ & $\begin{array}{l}\text { I1: caucasians } 100 \\
\mathrm{C} 1 \text { : caucasians } 100\end{array}$ & ? \\
\hline $\begin{array}{l}\text { Duration of disease [years], } \\
\text { mean (SD) }\end{array}$ & $\begin{array}{l}\mathrm{I} 1: 6(3) \\
\mathrm{C} 1: 5(2)\end{array}$ & $\begin{array}{l}\mathrm{I} 1: 5(4) \\
\mathrm{C} 1: 6(4)\end{array}$ & $\begin{array}{l}\mathrm{I} 1: 5(3) \\
\mathrm{C} 1: 4(3)\end{array}$ \\
\hline $\begin{array}{l}\text { Body mass index }[\mathrm{kg} / \mathrm{m} 2] \text {, } \\
\text { mean }(\mathrm{SD})\end{array}$ & $\begin{array}{l}\text { I1: } 24.3(0.7) \\
\text { C1: } 24.4(0.8)\end{array}$ & $\begin{array}{l}\text { I1: } 26.4(1.4) \\
\mathrm{C} 1: 26.9(1.2)\end{array}$ & $\begin{array}{l}\text { I1: } 26.6(1.3) \\
\text { C1: } 26.8(1.5)\end{array}$ \\
\hline
\end{tabular}


(Continued)

\begin{tabular}{l|l|l|l}
\hline $\begin{array}{l}\text { Pharmaco-naive patients [\%] } \\
\text { I1: none } \\
\text { C1: none }\end{array}$ & $\begin{array}{l}\text { I1: none } \\
\text { C1: none }\end{array}$ & $\begin{array}{l}\text { I1: none } \\
\text { C1: none }\end{array}$ \\
\hline $\begin{array}{l}\text { HbA1c [\%], mean (SD) } \\
\text { I1: } 8.0(0.8) \\
\text { C1: } 8.2(0.7)\end{array}$ & $\begin{array}{l}\text { I1: } 8.1(0.9) \\
\text { C1: } 8.2(0.8)\end{array}$ & $\begin{array}{l}\text { I1: } 8.0(0.7) \\
\text { C1: } 7.9(0.6)\end{array}$ \\
\hline $\begin{array}{l}\text { Co-morbidities [\%] } \\
\text { Notes }\end{array}$ & patients who completed the &.$/$. & $\begin{array}{l}\text { I1: hypertension } 42 \\
\text { C1: hypertension } 47\end{array}$ \\
\hline $\begin{array}{l}\text { Footnotes } \\
?=\text { study }\end{array}$ & &.$/$. \\
\hline
\end{tabular}

Appendix 3. Baseline characteristics (II)

\begin{tabular}{|c|c|c|c|c|c|}
\hline Characteristic & Garber 2006 & Goldberg 2005 & Hanefeld 2007 & Hällsten 2002 & Jung 2005 \\
\hline & $\begin{array}{l}\text { I1: rosiglitazone } 4 \\
\mathrm{mg}+\text { metformin } \\
2000 \\
\mathrm{C} 1: \text { glibenclamide } \\
5 \mathrm{mg}+\text { metformin } \\
1000 \mathrm{mg}\end{array}$ & $\begin{array}{l}\text { I1: rosiglitazone } 8 \\
\mathrm{mg}+\text { diet } \\
\mathrm{C} 1 \text { : pioglitazone } 45 \\
\mathrm{mg}+\text { diet }\end{array}$ & $\begin{array}{l}\text { I1: rosiglitazone } 4 \\
\text { mg + placebo } \\
\text { I2: rosiglitazone } 8 \\
\text { mg + placebo } \\
\mathrm{C} 1 \text { : glibenclamide + } \\
\text { placebo }\end{array}$ & $\begin{array}{l}\text { I1: rosiglitazone } 8 \\
\mathrm{mg} \\
\mathrm{C} 1 \text { : metformin } 2 \mathrm{~g} \\
\mathrm{C} 2 \text { : placebo }\end{array}$ & $\begin{array}{l}\text { I1: rosiglitazone } 4 \\
\text { mg + glimepiride } 4 \\
\text { mg } \\
\mathrm{C} 1: \\
\text { metformin } 1000 \mathrm{mg} \\
+ \text { glimepiride } 4 \mathrm{mg}\end{array}$ \\
\hline Sex $[\%]$ & $\begin{array}{l}\text { I1: female } 35 ; \text { male } \\
65 \\
\text { C1: female 44; male } \\
56\end{array}$ & $\begin{array}{l}\text { I1: female } 45 \text {; male } \\
55 \\
\text { C1: female } 46 \text {; male } \\
54\end{array}$ & $\begin{array}{l}\text { I1: female } 32 \text {; male } \\
68 \\
\text { I2: female } 42 \text {; male } \\
58 \\
\mathrm{C} 1 \text { : female } 30 \text {; male } \\
70\end{array}$ & $\begin{array}{l}\text { I1: female } 29 \text {; male } \\
71 \\
\text { C1: female } 38 \text {; male } \\
62 \\
\text { C2: female } 29 \text {; male } \\
71\end{array}$ & $\begin{array}{l}\text { I1: female 57; male } \\
43 \\
\text { C1: female 54; male } \\
46\end{array}$ \\
\hline $\begin{array}{l}\text { Age [years], mean } \\
\text { (SD) }\end{array}$ & $\begin{array}{l}\mathrm{I} 1: 56 \\
\mathrm{C} 1: 56\end{array}$ & $\begin{array}{l}\text { I1: } 56.3(11.3) \\
\text { C1: } 55.9(10.5)\end{array}$ & $\begin{array}{l}\text { I1: } 60.4(8.2) \\
\text { I2: } 60.6(9.2) \\
\text { C1: } 60.1(8.3)\end{array}$ & $\begin{array}{l}\text { I1: } 58.6(7.5) \\
\text { C1: } 57.8(7.9) \\
\text { C2: } 57.7(7.1)\end{array}$ & $\begin{array}{l}\mathrm{I} 1: 60(8) \\
\mathrm{C} 1: 54(14)\end{array}$ \\
\hline Ethnic groups [\%] & $\begin{array}{l}\text { I1: white } 79 \text {; black } \\
6 \text {; hispanic/latino } \\
\text { 10; asian/pacific is- } \\
\text { lander } 3 \text {; other } 3 \\
\text { C1: white } 80 \text {; black } \\
5 \text {; hispanic/latino }\end{array}$ & $\begin{array}{l}\text { I1: white } 60 \text {; his- } \\
\text { panic } 32 \text {; asian } 3 \text {; } \\
\text { african } 3 \text {; other } 2 \\
\mathrm{C} 1 \text { : white } 65 \text {; his- } \\
\text { panic } 29 \text {; asian } 3 \text {; } \\
\text { african } 2 \text {; other } 2\end{array}$ & $\begin{array}{l}\text { I1: white 99; other } \\
1 \\
\text { I2: white 97; other } \\
3 \\
\text { C1: white 99.5; } \\
\text { other } 0.5\end{array}$ & ? & $\begin{array}{l}\text { I1: korean } 100 \\
\text { C1: korean } 100\end{array}$ \\
\hline
\end{tabular}




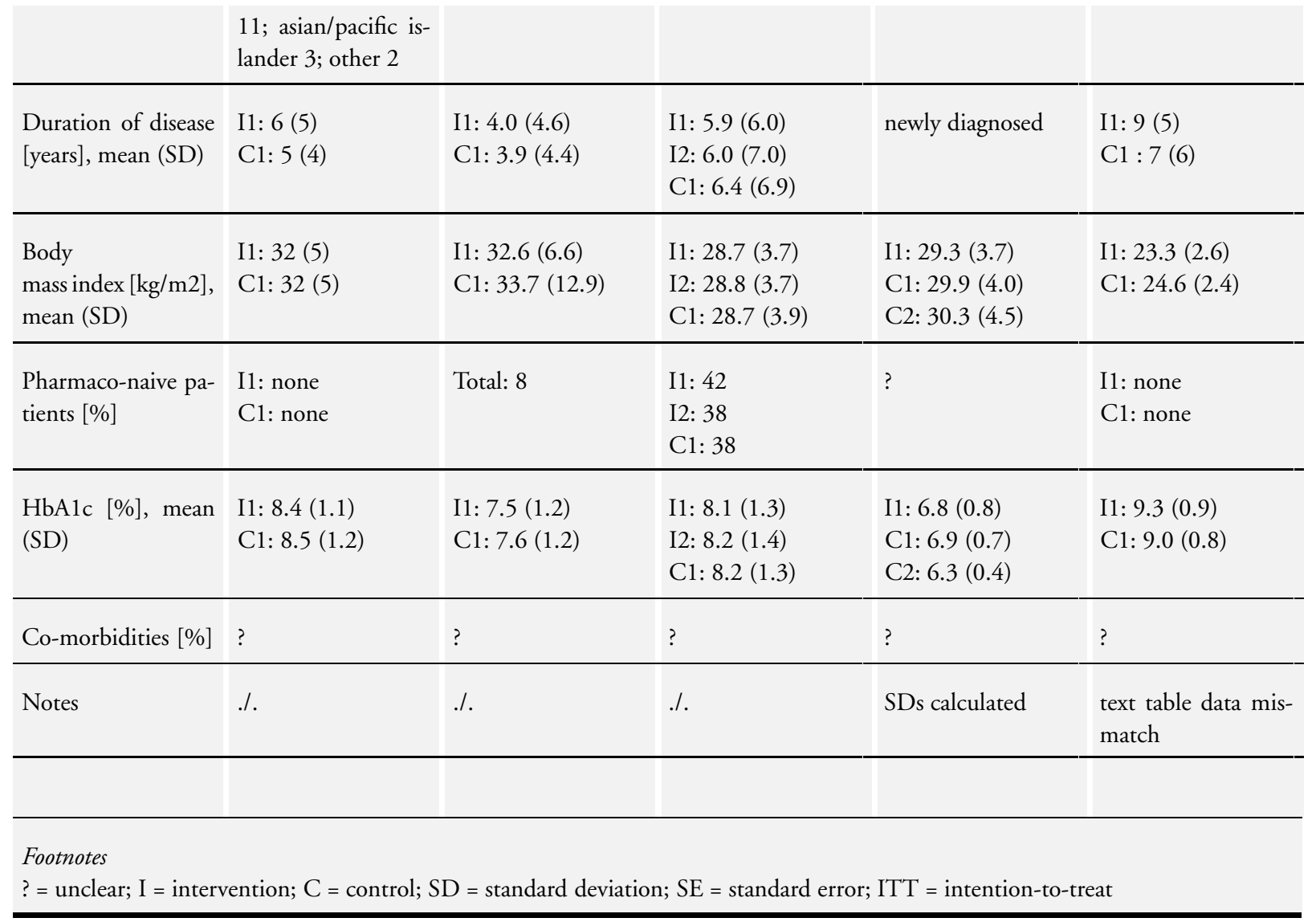

\section{Appendix 4. Baseline characteristics (III)}

\begin{tabular}{|c|c|c|c|c|c|c|}
\hline Characteristic & Kahn 2006 & Ко 2006 & Lebovitz 2001 & Ovalle 2004 & Philipps 2001 & Raskin 2004 \\
\hline & $\begin{array}{l}\text { Kahn } 2006 \\
\text { I1: rosiglitazone } \\
\text { max. } 8 \mathrm{mg} \\
\mathrm{C} 1: \text { metformin } \\
\text { max. } 2 \mathrm{~g} \\
\mathrm{C} 2: \quad \text { glyburide } \\
\text { max. } 15 \mathrm{mg}\end{array}$ & $\begin{array}{l}\text { I1: rosiglitazone } \\
\text { max. } 8 \mathrm{mg} \\
+\quad \text { (sulfonylurea } \\
\text { +/- metformin) } \\
\text { C1: "bedtime in- } \\
\text { sulin" } \\
+\quad \text { (sulfonylurea } \\
\text { +/- metformin) }\end{array}$ & $\begin{array}{l}\text { I1: rosiglitazone } \\
4 \mathrm{mg} \\
\mathrm{I} 2: \text { rosiglitazone } \\
8 \mathrm{mg} \\
\mathrm{C} 1 \text { : placebo }\end{array}$ & $\begin{array}{l}\text { I1: rosiglitazone } \\
8 \mathrm{mg} \\
\mathrm{C} 1 \text { : insulin } 70 / \\
30\end{array}$ & $\begin{array}{l}\text { I1: rosiglitazone } \\
4 \mathrm{mg} \\
\text { I2: rosiglitazone } \\
2 \times 2 \mathrm{mg} \\
\text { I3: rosigllitazone } \\
8 \mathrm{mg} \\
\text { I4: rosiglitazone } \\
2 \times 4 \mathrm{mg} \\
\mathrm{C} 1: \text { placebo }\end{array}$ & $\begin{array}{l}\text { I1: rosiglitazone } \\
8 \mathrm{mg} \\
\mathrm{C} 1 \text { : repaglinide } \\
12 \mathrm{mg} \\
\mathrm{C} 2 \text { : rosiglitazone } \\
4 \mathrm{mg}+\text { repaglin- } \\
\text { ide } 6 \mathrm{mg}\end{array}$ \\
\hline Sex $[\%]$ & $\begin{array}{l}\text { I1: female } 44 ; \\
\text { male } 56 \\
\text { C1: female } 40 \text {; }\end{array}$ & $\begin{array}{l}\text { I1: female } 43 ; \\
\text { male } 57 \\
\text { C1: female } 57 ;\end{array}$ & $\begin{array}{l}\text { I1: female } 36 ; \\
\text { male } 64 \\
\text { I2: female } 33 ;\end{array}$ & ? & $\begin{array}{l}\text { I1: female } 41 \text {; } \\
\text { male } 59 \\
\text { I2: female } 41 \text {; }\end{array}$ & $\begin{array}{l}\text { I1: female } 47 \text {; } \\
\text { male } 53 \\
\text { C1: female } 38 \text {; }\end{array}$ \\
\hline
\end{tabular}




\begin{tabular}{|c|c|c|c|c|c|c|}
\hline & $\begin{array}{l}\text { male } 60 \\
\text { C2: female } 42 \text {; } \\
\text { male } 58\end{array}$ & male 43 & $\begin{array}{l}\text { male } 67 \\
\text { C1: female } 34 ; \\
\text { male } 66\end{array}$ & & $\begin{array}{l}\text { male } 59 \\
\text { I3: female } 34 ; \\
\text { male } 66 \\
\text { I4: female } 35 ; \\
\text { male } 65 \\
\text { C1: female } 31 ; \\
\text { male } 69\end{array}$ & $\begin{array}{l}\text { male } 62 \\
\text { C2: female } 49 ; \\
\text { male } 51\end{array}$ \\
\hline $\begin{array}{l}\text { Age [years], } \\
\text { mean (SD) }\end{array}$ & $\begin{array}{l}\text { I1: } 56.3(10.0) \\
\text { C1: } 57.9(9.9) \\
\text { C2: } 56.4(10.2)\end{array}$ & $\begin{array}{l}\text { I1: } 56.6(10.7) \\
\text { C1: } 59.8(11.2)\end{array}$ & $\begin{array}{l}\text { I1: } 60(9.8) \\
\text { I2: } 61(9.5) \\
\text { C1: } 59(10.9)\end{array}$ & $\begin{array}{l}\text { I1: } 47(12) \\
\text { C1: } 56(14.1)\end{array}$ & $\begin{array}{l}\text { I1: } 57.5(9.9) \\
\text { I2: } 56.8(9.4) \\
\text { I3: } 58.9(9.9) \\
\text { I4: } 56.5(9.7) \\
\text { C1: } 57.7(9.2)\end{array}$ & $\begin{array}{l}\text { I1: } 56.6(10.8) \\
\text { C1: } 58.5(10.1) \\
\text { C2: } 57.5(10.8)\end{array}$ \\
\hline $\begin{array}{l}\text { Ethnic groups } \\
{[\%]}\end{array}$ & $\begin{array}{l}\text { I1: white } 87 \text {; } \\
\text { black 4; asian 3; } \\
\text { hispanic 5; other } \\
1 \\
\text { C1: white } 89 \text {; } \\
\text { black 4; asian 2; } \\
\text { hispanic 4; other } \\
1 \\
\text { C2: white } 89 \text {; } \\
\text { black 4; asian 2; } \\
\text { hispanic 4; other } \\
0.3\end{array}$ & Chinese patients & $\begin{array}{l}\text { I1: white } 75 \text {; } \\
\text { black } 8 \text {; other } 16 \\
\text { I2: white } 73 \text {; } \\
\text { black 9; other } 17 \\
\text { C1: white } 74 \text {; } \\
\text { black } 8 \text {; other } 18\end{array}$ & ? & $\begin{array}{l}\text { I1: } \\
\text { white } 76 \text {; black } \\
\text { 13; other } 11 \\
\text { I2: white } 78 \text {; } \\
\text { black } 8 \text {; other } 14 \\
\text { I3: white } 80 \text {; } \\
\text { black } 7 \text {; other } 13 \\
\text { I4: } \\
\text { white } 71 \text {; black } \\
\text { 11; other } 18 \\
\text { C1: white } 79 \text {; } \\
\text { black 9; other } 12\end{array}$ & $\begin{array}{l}\text { I1: caucasian } 68 \text {; } \\
\text { black 13; his- } \\
\text { panic } 0 \text {; other } 19 \\
\mathrm{C} 1 \text { : caucasian } \\
63 \text {; black } 16 \text {; his- } \\
\text { panic } 2 \text {; other } 19 \\
\mathrm{C} 2 \text { : caucasian } \\
65 \text {; black } 17 \text {; his- } \\
\text { panic } 3 \text {; other } 15\end{array}$ \\
\hline $\begin{array}{l}\text { Duration of dis- } \\
\text { ease [years], } \\
\text { mean (SD) }\end{array}$ & ? & $\begin{array}{l}\text { I1: } 11.8(7.7) \\
\text { C1: } 13.6(7.5)\end{array}$ & $\begin{array}{l}\text { I1: } 4.8(5.8) \\
\text { I2: } 5.4(6.0) \\
\text { C1: } 4.6(4.8)\end{array}$ & $\begin{array}{l}\text { I1: } 7.6(6.3) \\
\text { C1: } 7.6(4.8)\end{array}$ & $\begin{array}{l}\text { I1: } 5.4(6.1) \\
\text { I2: } 5.5(4.9) \\
\text { I3: } 6.1(6.7) \\
\text { I4: } 5.9(6.1) \\
\text { C1: } 6.6(6.9)\end{array}$ & $\begin{array}{l}\text { I1: } 7.4(6.6) \\
\text { C1: } 7.2(5.3) \\
\text { C2: } 7.3(6.9)\end{array}$ \\
\hline $\begin{array}{l}\text { Body mass index } \\
{[\mathrm{kg} / \mathrm{m} 2], \text { mean }} \\
(\mathrm{SD})\end{array}$ & $\begin{array}{l}\text { I1: } 32.2(6.7) \\
\text { C1: } 32.1(6.1) \\
\text { C2: } 32.2(6.3)\end{array}$ & $\begin{array}{l}\text { I1: } 25.3(3.8) \\
\text { C1: } 24.0(2.7)\end{array}$ & $\begin{array}{l}\text { I1: } 30.2(4.1) \\
\text { I2: } 29.1(3.9) \\
\text { C1: } 29.9(4.1)\end{array}$ & $\begin{array}{l}\text { I1: } 31.5(6.9) \\
\text { C1: } 30.8(7.6)\end{array}$ & $\begin{array}{l}\text { I1: } 29.9(4.1) \\
\text { I2: } 30.0(4.2) \\
\text { I3: } 30.0(4.3) \\
\text { I4: } 29.9(4.3) \\
\text { C1: } 29.1(4.2)\end{array}$ & $\begin{array}{l}\text { I1: } 31.4(5.2) \\
\text { C1: } 30.4(4.7) \\
\text { C2: } 32.3(5.2)\end{array}$ \\
\hline $\begin{array}{l}\text { Pharmaco-naive } \\
\text { patients [\%] }\end{array}$ & $\begin{array}{l}\text { I1: } 100 \\
\text { C1: } 100 \\
\text { C2: } 100\end{array}$ & ? & $\begin{array}{l}\mathrm{I} 1: 26.5 \\
\mathrm{I} 2: 26.6 \\
\mathrm{C} 1: 28.5\end{array}$ & $\begin{array}{l}\text { I1: none } \\
\mathrm{C} 1 \text { : none }\end{array}$ & $\begin{array}{lll}\text { I1: } & 22.1 & (40 / \\
\text { 181) } & \\
\text { I2: } 24.7 & (46 / \\
\text { 186) } & \\
\text { I3: } 29.3 & (53 / \\
\text { 181) } & \\
\text { I4: } 25.1 & (47 / \\
\text { 187) } \\
\text { C1: } 22.5 \\
\text { 173) }\end{array}$ & $\begin{array}{l}\text { I1: none } \\
\text { C1: none } \\
\text { C2: none }\end{array}$ \\
\hline
\end{tabular}


(Continued)

\begin{tabular}{|c|c|c|c|c|c|c|}
\hline $\begin{array}{l}\text { HbAlc } \quad[\%], \\
\text { mean }(\mathrm{SD})\end{array}$ & $\begin{array}{l}\text { I1: } 7.4(0.9) \\
\text { C1: } 7.4(0.9) \\
\text { C2: } 7.4(0.9)\end{array}$ & $\begin{array}{l}\text { I1: } 10.1(1.0) \\
\text { C1: } 9.6(0.9)\end{array}$ & $\begin{array}{l}\text { I1: } 9.0(1.5) \\
\text { I2: } 8.8(1.6) \\
\text { C1: } 9.0(1.7)\end{array}$ & $\begin{array}{l}\text { I1: } 8.7 \\
\text { C1: } 9.0\end{array}$ & $\begin{array}{l}\text { I1: } 8.9(1.6) \\
\text { I2: } 8.9(1.5) \\
\text { I3:8.9 }(1.5) \\
\text { I4:9.0 }(1.5) \\
\text { C1: } 8.9(1.5)\end{array}$ & $\begin{array}{l}\text { I1: } 9.0 \\
\text { C1: } 9.3 \\
\text { C2: } 9.1\end{array}$ \\
\hline $\begin{array}{l}\text { Co-morbidities } \\
{[\%]}\end{array}$ & ? & ? & ? & ? & ? & ? \\
\hline Notes & $\begin{array}{l}\text { antihypertensive } \\
\text { therapy: } \\
\text { I1: } 51 \% \text {; C1: } \\
51 \% \text {; C2: } 52 \%\end{array}$ & $\begin{array}{l}\text { antihypertensive } \\
\text { agents: } \\
\text { I1: 55\%; C1: } \\
\text { 25\% } \\
\text { lipid-lowering } \\
\text { agents: } \\
\text { I1: } 9 \% \text {; C1: 4\% }\end{array}$ & ITT population & SDs calculated & ITT population &.$/$. \\
\hline
\end{tabular}

Footnotes

? = unclear; $\mathrm{I}=$ intervention; $\mathrm{C}=$ control; $\mathrm{SD}=$ standard deviation; $\mathrm{SE}=$ standard error; ITT = intention-to-treat

\section{Appendix 5. Baseline characteristics (IV)}

\begin{tabular}{|c|c|c|c|c|}
\hline Characteristic & Rosenstock 2006b & Stocker 2007 & Sutton 2002 & Yang 2002 \\
\hline & $\begin{array}{l}\text { I1: rosiglitazone until } 8 \\
\mathrm{mg}+\text { sulfonyurea }+ \text { max. } \\
2 \mathrm{~g} \text { metformin } \\
\mathrm{C} 1 \text { : } \\
\text { insulin glargine max. } 10 \\
\mathrm{U}+\text { sulfonylurea + max. } \\
2 \mathrm{~g} \text { metformin }\end{array}$ & $\begin{array}{l}\mathrm{I} 1: \text { rosiglitazone } 4 \mathrm{mg} \\
\mathrm{C} 1: \text { metformin } 1.7 \mathrm{~g}\end{array}$ & $\begin{array}{l}\text { I1: rosiglitazone } 8 \mathrm{mg} \\
\mathrm{C} 1 \text { : glyburide less than } \\
20 \mathrm{mg}\end{array}$ & $\begin{array}{l}\text { I1: rosiglitazone } 4 \mathrm{mg} \\
\mathrm{C} 1 \text { : placebo }\end{array}$ \\
\hline Sex $[\%]$ & $\begin{array}{l}\text { I1:female } 42 \text {; male } 58 \\
\text { C1: female } 55 \text {; male } 45\end{array}$ & $\begin{array}{l}\text { I1: female } 29 ; \text { male } 71 \\
\text { C1: female } 47 \text {; male } 53\end{array}$ & $\begin{array}{l}\text { I1: female } 25 \text {; male } 75 \\
\text { C1: female } 29 \text {; male } 71\end{array}$ & $\begin{array}{l}\text { I1: female } 57 \text {; male } 43 \\
\text { C1: female } 62 \text {; male } 38\end{array}$ \\
\hline Age [years], mean (SD) & $\begin{array}{l}\text { I1: } 55.3(11.4) \\
\text { C1: } 55.9(10.5)\end{array}$ & $\begin{array}{l}\text { I1: } 64(11) \\
\text { C1: } 65(10)\end{array}$ & $\begin{array}{l}\text { I1: } 55.1(9.0) \\
\text { C1: } 56.1(8.9)\end{array}$ & $\begin{array}{l}\text { I1: } 58.9(9.4) \\
\text { C1: } 57.8(8.9)\end{array}$ \\
\hline Ethnic groups [\%] & ? & ? & $\begin{array}{l}\text { I1: white } 73 \text {; black } 5 \text {; } \\
\text { other } 22 \\
\text { C1: white } 76 \text {; black } 3 \text {; } \\
\text { other } 21\end{array}$ & ? \\
\hline
\end{tabular}


(Continued)

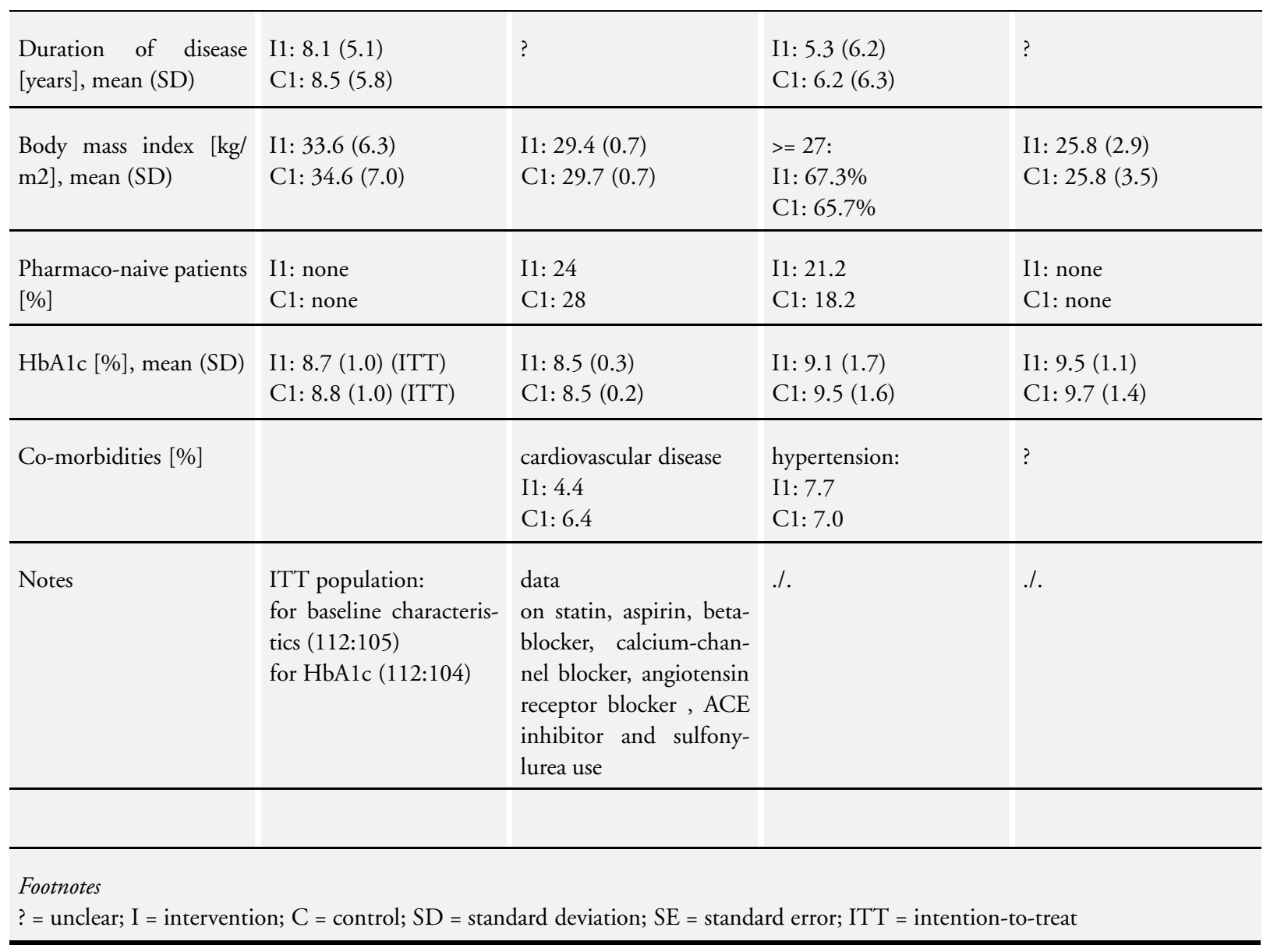

\section{Appendix 6. Adverse events (I)}

\begin{tabular}{|c|c|c|c|}
\hline Characteristic & Derosa 2004 & Derosa 2006a & Derosa 2006b \\
\hline & $\begin{array}{l}\text { I1: rosiglitazone } 4 \mathrm{mg} \mathrm{+} \\
\text { glimepiride } 4 \mathrm{mg} \\
\mathrm{C} 1 \text { : pioglitazone } 15 \mathrm{mg}+ \\
\text { glimepiride } 4 \mathrm{mg}\end{array}$ & $\begin{array}{l}\mathrm{I} 1 \text { : rosiglitazone } 4 \mathrm{mg}+\text { met- } \\
\text { formin } 3000 \mathrm{mg} \\
\mathrm{C} 1 \text { : pioglitazone } 15 \mathrm{mg}+\text { met- } \\
\text { formin } 3000 \mathrm{mg}\end{array}$ & $\begin{array}{l}\mathrm{I} 1 \text { : rosiglitazone } 4 \mathrm{mg}+\text { met- } \\
\text { formin } 1500 \mathrm{mg} \\
\mathrm{C} 1 \text { : glimepiride } 2 \mathrm{mg}+\text { met- } \\
\text { formin } 1500 \mathrm{mg}\end{array}$ \\
\hline [n] of participants who died & $\begin{array}{l}\text { I1: } 0 \\
\text { C1: } 0\end{array}$ & $?$ & $\begin{array}{l}\text { I1: } 0 \\
\text { C1:0 }\end{array}$ \\
\hline [\%] adverse events & $\begin{array}{l}\text { I1: } 11.9(5 / 42) \\
\text { C1: } 6.7(3 / 45)\end{array}$ & $\begin{array}{l}\text { I1: } 10.4(5 / 48) \\
\text { C1: } 8.3(4 / 48)\end{array}$ & $\begin{array}{l}\text { I: } 12.5(6 / 48) \\
\text { C1:8.5 (4/47) }\end{array}$ \\
\hline
\end{tabular}


(Continued)

\begin{tabular}{|c|c|c|c|}
\hline [\%] serious adverse events & $\begin{array}{l}\text { I1: } 0 \\
\mathrm{C} 1: 0\end{array}$ & ? & ? \\
\hline $\begin{array}{l}\text { [\%] drop-outs due to adverse } \\
\text { events }\end{array}$ & $\begin{array}{l}\text { I1: } 0 \\
\text { C1: } 0\end{array}$ & ? & ? \\
\hline [\%] oedema & ? & ? & ? \\
\hline haemoglobin $[\mathrm{g} / \mathrm{dl}]$ & ? & ? & ? \\
\hline body weight $[\mathrm{kg}]$ & ? & ? & $\begin{array}{l}\text { I1: ? } \\
\text { C1: ? }\end{array}$ \\
\hline $\begin{array}{l}\text { body mass index (BMI) }[\mathrm{kg} / \\
\mathrm{m} 2]\end{array}$ & $\begin{array}{l}\mathrm{I} 1:+1.5 \\
\mathrm{C} 1:+1.2\end{array}$ & $\begin{array}{l}\text { I1: }-0.4 \\
\text { C1: }-0.3\end{array}$ & $\begin{array}{l}\text { I1: }-2.1 \\
\text { C1: }-1.6\end{array}$ \\
\hline [\%] hypoglycaemic episodes & ? & $?$ & ? \\
\hline $\begin{array}{l}{[\%] \text { severe hypoglycaemic }} \\
\text { episodes }\end{array}$ & ? & ? & ? \\
\hline Notes & BMI change date calculated & BMI change data calculated & BMI change date calculated \\
\hline $\begin{array}{l}\text { Footnotes } \\
? \text { = unclear; I = intervention; C }\end{array}$ & control & & \\
\hline
\end{tabular}

\section{Appendix 7. Adverse events (II)}

\begin{tabular}{|c|c|c|c|c|c|}
\hline Characteristic & Garber 2006 & Goldberg 2005 & Hällsten 2002 & Hanefeld 2007 & Jung 2005 \\
\hline & $\begin{array}{l}\text { I1: rosiglitazone } 4 \\
\mathrm{mg}+\text { metformin } \\
2000 \\
\mathrm{C} 1: \text { glibenclamide } \\
5 \mathrm{mg}+\text { metformin } \\
1000 \mathrm{mg}\end{array}$ & $\begin{array}{l}\text { I1: rosiglitazone } 8 \\
\mathrm{mg}+\text { diet } \\
\mathrm{C} 1 \text { : pioglitazone } 45 \\
\mathrm{mg}+\text { diet }\end{array}$ & $\begin{array}{l}\text { I1: rosiglitazone } 8 \\
\mathrm{mg} \\
\mathrm{C} 1 \text { : metformin } 2 \mathrm{~g} \\
\mathrm{C} 2 \text { : placebo }\end{array}$ & $\begin{array}{l}\text { I1: rosiglitazone }(2 \\
\text { mg bid) + placebo } \\
\text { I2: rosiglitazone ( } 4 \\
\text { mg bid) + placebo } \\
\mathrm{C} 1: \text { glibenclamide } \\
\text { up to } 15 \mathrm{mg}+ \\
\text { placebo }\end{array}$ & $\begin{array}{l}\text { I1: } \\
\text { rosiglitazone } 4 \mathrm{mg}+ \\
\text { glimepiride } 4 \mathrm{mg} \\
\mathrm{C} 1: \\
\text { metformin } 1000 \mathrm{mg} \\
+ \text { glimepiride } 4 \mathrm{mg}\end{array}$ \\
\hline $\begin{array}{l}\text { [n] of participants } \\
\text { who died }\end{array}$ & $?$ & $\begin{array}{l}\mathrm{I} 1: 2 \\
\mathrm{C} 1: 1\end{array}$ & $\begin{array}{l}\mathrm{I} 1: 0 \\
\mathrm{C} 2: 0 \\
\mathrm{C} 1: 0\end{array}$ & $\begin{array}{l}\text { I1: } 0 \\
\text { I2: } 0 \\
\text { C1: } 0\end{array}$ & ? \\
\hline
\end{tabular}


(Continued)

\begin{tabular}{|c|c|c|c|c|c|}
\hline [\%] adverse events & $\begin{array}{l}\text { I1: } 63(98 / 155) \\
\text { C1: } 68(108 / 160)\end{array}$ & ? & $?$ & $\begin{array}{l}\text { I1: } 75.0(150 / 200) \\
\text { I2: } 75.4(144 / 191) \\
\text { C1: } 69.6(144 / 207)\end{array}$ & ? \\
\hline $\begin{array}{l}{[\%] \text { serious adverse }} \\
\text { events }\end{array}$ & $\begin{array}{l}\text { I1: } 6(9 / 155) \\
\text { C1: } 4(7 / 159)\end{array}$ & ? & ? & ? & ? \\
\hline $\begin{array}{l}\text { [\%] drop-outs due } \\
\text { to adverse events }\end{array}$ & $\begin{array}{l}\text { I1: } 4.4(7 / 158) \\
\text { C1: } 10(16 / 160)\end{array}$ & $\begin{array}{l}\text { I1: } 2.7(10 / 366) \\
C 1: 2.7(10 / 369)\end{array}$ & $\begin{array}{l}\mathrm{I} 1: 0 \\
\mathrm{C} 2: 0 \\
\mathrm{C} 1: 0\end{array}$ & $\begin{array}{l}\mathrm{I} 1: 6 \\
\mathrm{I} 2: 4.7 \\
\mathrm{C} 1: 6.3\end{array}$ & $\begin{array}{l}\text { I1:? } \\
\text { C1: } 3.3(1 / 30)\end{array}$ \\
\hline [\%] oedema & $?$ & ? & ? & $\begin{array}{l}\text { I1: } 3.5(7 / 200) \\
\text { I2: } 8.9(17 / 191) \\
\text { C1: } 1.9(4 / 207)\end{array}$ & ? \\
\hline haemoglobin $[\mathrm{g} / \mathrm{dl}]$ & $?$ & ? & ? & $\begin{array}{l}\text { I1: }-0.48 \\
\text { I2: }-0.98 \\
\text { C1: } 0\end{array}$ & ? \\
\hline body weight [kg] & $\begin{array}{l}\mathrm{I} 1:+1.4 \\
\mathrm{C} 1:+3\end{array}$ & $\begin{array}{l}\text { I1: } 1.6 \\
\text { C1: } 2.0\end{array}$ & $\begin{array}{l}\mathrm{I} 1:+0.6 \\
\mathrm{C} 1:-2.0 \\
\mathrm{C} 2:+0.1\end{array}$ & $\begin{array}{l}\text { I1: } 1.75 \\
\text { I2: } 2.95 \\
\text { C1: } 1.9\end{array}$ & ? \\
\hline $\begin{array}{l}\text { body mass index } \\
(\mathrm{BMI})[\mathrm{kg} / \mathrm{m} 2]\end{array}$ & $?$ & ? & ? & ? & ? \\
\hline $\begin{array}{l}\text { [\%] hypoglycaemic } \\
\text { episodes }\end{array}$ & $\begin{array}{l}\text { I1: } 26(41 / 155) \\
\text { C1: } 73(116 / 159)\end{array}$ & ? & ? & $\begin{array}{l}\text { I1: } 0.5(1 / 200) \\
\text { I2: } 1.6(3 / 191) \\
\text { C1: } 12.1(25 / 207)\end{array}$ & $?$ \\
\hline $\begin{array}{l}{[\%] \text { severe hypogly- }} \\
\text { caemic episodes }\end{array}$ & $?$ & ? & $?$ & $\begin{array}{l}\text { I1: } \\
\text { I2: } \\
\text { C1: } 0.01\end{array}$ & $?$ \\
\hline Notes & $\begin{array}{l}\text { elevated levels of } \\
\text { ALT ( }>3 x \text { pretreat- } \\
\text { ment levels and > } \\
\text { upper normal limit) } \\
: \\
\text { I1: } 2 \text { patients } \\
\text { C1: } 3 \text { patients }\end{array}$ & $\begin{array}{l}\text { I1 + C1: no signifi- } \\
\text { cant differences ob- } \\
\text { served for: } \\
\text { - liver functions } \\
\text { tests } \\
\text { - haemoglobin ans } \\
\text { haematocrit } \\
\text { - hypoglycemic } \\
\text { episodes } \\
\text { - adverse events } \\
\text { (oedema, congestive } \\
\text { heart failure) }\end{array}$ & $\begin{array}{l}\text { body weight change } \\
\text { data calculated }\end{array}$ & $\begin{array}{l}\text { two hypoglycaemic } \\
\text { events were severe } \\
\text { and one required } \\
\text { hospitalization; un- } \\
\text { clear in which med- } \\
\text { ication group these } \\
\text { events happened }\end{array}$ &. \\
\hline
\end{tabular}


(Continued)

Footnotes

? = unclear; $\mathrm{I}=$ intervention; $\mathrm{C}$ = control; $\mathrm{AE}$ = adverse event; $\mathrm{ALT}=$ alanine aminotransferase

Appendix 8. Adverse events (III)

\begin{tabular}{|c|c|c|c|c|c|c|}
\hline Characteristic & Kahn 2006 & Кo 2006 & Lebovitz 2001 & Ovalle 2004 & Philipps 2001 & Raskin 2004 \\
\hline & $\begin{array}{l}\text { I1: rosiglitazone } \\
\text { max. } 8 \mathrm{mg} \\
\mathrm{C} 1: \text { metformin } \\
\text { max. } 2 \mathrm{~g} \\
\mathrm{C} 2: \quad \text { glyburide } \\
\text { max. } 15 \mathrm{mg}\end{array}$ & $\begin{array}{l}\text { I1: rosiglitazone } \\
\text { max. } 8 \mathrm{mg} \\
+\quad \text { (sulfonylurea } \\
\text { +/- metformin) } \\
\text { C1: "bedtime in- } \\
\text { sulin" } \\
+\quad \text { (sulfonylurea } \\
+/ \text { - metformin) }\end{array}$ & $\begin{array}{l}\text { I1: rosiglitazone } \\
4 \mathrm{mg} \\
\text { I2: rosiglitazone } \\
8 \mathrm{mg} \\
\mathrm{C} 1 \text { : placebo }\end{array}$ & $\begin{array}{l}\text { I1: rosiglitazone } \\
8 \mathrm{mg} \\
\mathrm{C} 1 \text { : insulin } 70 / \\
30\end{array}$ & $\begin{array}{l}\text { I1: rosiglitazone } \\
4 \mathrm{mg} \\
\text { I2: rosiglitazone } \\
2 \times 2 \mathrm{mg} \\
\text { I3: rosigllitazone } \\
8 \mathrm{mg} \\
\mathrm{I} 4: \text { rosiglitazone } \\
2 \times 4 \mathrm{mg} \\
\mathrm{C} 1: \text { placebo }\end{array}$ & $\begin{array}{l}\mathrm{I} 1: \text { rosiglitazone } \\
8 \mathrm{mg} \\
\mathrm{C} 1: \text { repaglinide } \\
12 \mathrm{mg} \\
\mathrm{C} 2: \text { rosiglitazone } \\
4 \mathrm{mg}+\text { repaglin- } \\
\text { ide } 6 \mathrm{mg}\end{array}$ \\
\hline $\begin{array}{l}{[\mathrm{n}] \text { of partici- }} \\
\text { pants who died }\end{array}$ & $\begin{array}{l}\text { I1: } 34 \\
\text { C1: } 31 \\
\text { C2: } 31\end{array}$ & ? & ? & ? & ? & ? \\
\hline $\begin{array}{l}{[\%] \quad \text { adverse }} \\
\text { events }\end{array}$ & $\begin{array}{l}\text { I1: } 91.9(1338 / \\
\text { 1456) } \\
\text { C1: } 92.2(1341 / \\
\text { 1454) } \\
\text { C2: } 91.7(1321 / \\
1441)\end{array}$ & $\begin{array}{l}\text { I1: } 7.1 \\
\text { C1: } 10.7\end{array}$ & $\begin{array}{ll}\text { I1: } 73.1 & (121 / \\
\text { 166) } & \\
\text { I2: } 74.3 & (126 / \\
\text { 169) } & \\
\text { C1: } 69.9 & (110 / \\
158) & \end{array}$ & ? & $\begin{array}{l}\mathrm{I} 1+\mathrm{I} 2+\mathrm{I} 3+\mathrm{I} 4: \\
75 \\
(551 / 735) \\
\mathrm{C} 1: \quad 71 \quad(123 / \\
173)\end{array}$ & $\begin{array}{l}\text { I1: } 24(15 / 62) \\
\text { C1:37 }(23 / 63) \\
\text { C2: } 64(81 / 127)\end{array}$ \\
\hline $\begin{array}{l}{[\%] \text { serious ad- }} \\
\text { verse events }\end{array}$ & $\begin{array}{l}\text { I1: } 23.8 \\
\text { 1456) } \\
\text { C1: } 22.8 \quad(3346 / \\
\text { 1454) } \\
\text { C2: } 21.4 \quad(308 / \\
1441)\end{array}$ & $\begin{array}{l}\text { I1: } 5.4 \\
\text { C1: } 0\end{array}$ & $?$ & ? & ? & ? \\
\hline $\begin{array}{l}{[\%]} \\
\text { drop-outs due to } \\
\text { adverse events }\end{array}$ & $\begin{array}{l}\text { I1: } 11.6 \\
\text { C1: } 12.2 \\
\text { C2: } 14.9\end{array}$ & $\begin{array}{l}\text { I1: } 7.1 \\
\text { C1: } 0\end{array}$ & ? & ? & $\begin{array}{l}\mathrm{I} 1+\mathrm{I} 2+\mathrm{I} 3+\mathrm{I} 4: 5 \\
6(41 / 735) \\
\mathrm{C} 1: \quad 10.8 \quad(19 / \\
173)\end{array}$ & $\begin{array}{l}\text { I1: } 9.7(6 / 62) \\
\text { C1: } 6.3(4 / 63) \\
\text { C2: } 3.1(4 / 127)\end{array}$ \\
\hline [\%] oedema & $\begin{array}{l}\text { I1: } 14.1 \quad(205 / \\
\text { 1456) } \\
\text { C1: } 7.2 \quad(104 / \\
1454)\end{array}$ & $\begin{array}{l}\text { I1: } 3.6 \\
\text { C1: } 0\end{array}$ & 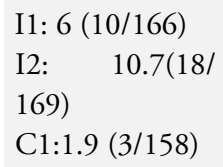 & ? & $\begin{array}{l}\text { I1: } 5.2(10 / 181) \\
\text { I2: } 4.1(8 / 186) \\
\text { I3: } 6.4(12 / 181) \\
\text { I4: } 6.6(13 / 187)\end{array}$ & $\begin{array}{l}\text { I1: } 3(2 / 62) \\
\text { C1: } 0 \\
\text { C2: } 4(5 / 125)\end{array}$ \\
\hline
\end{tabular}


(Continued)

\begin{tabular}{|c|c|c|c|c|c|c|}
\hline & $\begin{array}{l}\text { C2: } 8.5 \quad(123 / \\
1441)\end{array}$ & & & & C1: $1.6(3 / 173)$ & \\
\hline $\begin{array}{l}\text { haemoglobin [g/ } \\
\text { dl] }\end{array}$ & ? & ? & $\begin{array}{l}\text { I1: }-0.6 \\
\text { I2: }-1.0 \\
\text { C1: ? }\end{array}$ & ? & $\begin{array}{l}\mathrm{I} 1+\mathrm{I} 2+\mathrm{I} 3+\mathrm{I} 4: \\
-0.5 \text { to }-0.9 \\
\text { (dosage depen- } \\
\text { dent) } \\
\text { C: ? }\end{array}$ & $\begin{array}{l}\text { I1: }-0.7 \\
\text { C1: } 0 \\
\text { C2: }-0.8\end{array}$ \\
\hline body weight [kg] & ? & ? & $\begin{array}{l}\text { I1: } 1.6 \\
\text { I2: } 3.5 \\
\text { C1: }-1\end{array}$ & ? & $\begin{array}{l}\text { I1: } 1.2 \\
\text { I2: } 1.5 \\
\text { I3: } 2.6 \\
\text { I4: } 3.3 \\
\text { C1: }-0.9\end{array}$ & $\begin{array}{l}\mathrm{I} 1:+2.3 \\
\mathrm{C} 1:+1.6 \\
\mathrm{C} 2:+4.4\end{array}$ \\
\hline $\begin{array}{l}\text { body mass index } \\
(\mathrm{BMI}) \quad[\mathrm{kg} / \mathrm{m} 2] \\
(\mathrm{SD})\end{array}$ & ? & $\begin{array}{l}\text { I1: } 0.9(1.3) \\
\text { C1: } 0.8(0.9) \\
\text { change data after } \\
\text { one year }\end{array}$ & ? & ? & ? & ? \\
\hline $\begin{array}{l}{[\%] \text { hypogly- }} \\
\text { caemic episodes }\end{array}$ & $\begin{array}{l}\text { I1: } 9.8 \quad(142 / \\
1456) \\
\text { C1: } 11.6 \quad(168 / \\
\text { 1454) } \\
\text { C2: } 38.7 \quad(557 / \\
1441)\end{array}$ & $\begin{array}{l}\text { I1: } 0 \\
\text { C1: } 8.9\end{array}$ & $?$ & $?$ & $?$ & $\begin{array}{l}\text { I1: } 2(1 / 62) \\
\text { C1: } 6(4 / 63) \\
\text { C2: } 9(11 / 127)\end{array}$ \\
\hline $\begin{array}{l}{[\%] \text { severe hypo- }} \\
\text { glycaemic } \\
\text { episodes }\end{array}$ & $\begin{array}{l}\text { I1: } 0.1(2 / 1456) \\
\mathrm{C} 1: \quad 0.1 \\
1454) \\
\mathrm{C} 2: 0.6(8 / 1441)\end{array}$ & $\begin{array}{l}\text { I1: } 0 \\
\text { C1: } 0\end{array}$ & ? & ? & ? & $\begin{array}{l}\text { I1: } 0 \\
\text { C1: } 0 \\
\text { C2: <1 } \quad \text { (1 } \\
\text { episode) }\end{array}$ \\
\hline Notes &.$/$ & .1 &. &.$/$ & ITT population & $\begin{array}{l}\mathrm{C} 1 \text { : one patient } \\
\text { with elevated } \\
\text { liver transam- } \\
\text { inase ( }>3 \mathrm{X} \text { nor- } \\
\text { mal limit) }\end{array}$ \\
\hline
\end{tabular}

[n] fractures (\%) Men

I1: 32 (3.95)

C1: $29(3.36)$

C2: $28(3.35)$

Women

I1: 60 (9.30)

C1: $30(5.08)$

C2: $21(3.47)$

Lower limb 
(Continued)
I1: $36(5.58)$
C1: 18 (3.05)
C2: 8 (1.32)
Upper limb
I1: 22 (3.41)
C1: 10 (1.69)
C2: 9 (1.49)
Spinal
I1: 1 (0.16)
C1: $1(0.17)$
C2: $1(0.17)$

\begin{tabular}{|c|c|}
\hline $\begin{array}{l}{[\%] \quad \text { hospi- }} \\
\text { talization for any } \\
\text { cause }\end{array}$ & $\begin{array}{l}\text { I1: } 11.6 \quad(169 / \\
\text { 1456) } \\
\text { C1: } 11.8(172 / \\
1454) \\
\text { C2: } 10.4(150 / \\
1441)\end{array}$ \\
\hline $\begin{array}{l}{[\%] \text { cardiovascu- }} \\
\text { lar disease, total } \\
\text { events }\end{array}$ & $\begin{array}{lll}\text { I1: } \quad 4.3 & (62 / \\
1456) & \\
\text { C1: } 4.0 \quad(58 / \\
1454) \\
\text { C2: } 2.8 \quad(41 / \\
1441)\end{array}$ \\
\hline $\begin{array}{l}{[\%]} \\
\text { congestive heart } \\
\text { failure, investiga- } \\
\text { tor-reported, to- } \\
\text { tal events }\end{array}$ & $\begin{array}{l}\text { I1: } \quad 1.5 \quad(22 / \\
1456) \\
\text { C1: } 1.3 \quad(19 / \\
1454) \\
\text { C2: } 0.6(9 / 1441)\end{array}$ \\
\hline
\end{tabular}

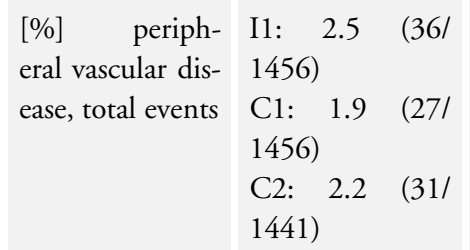

[\%] gastroin- I1: $23.0 \quad(335 /$

testinal events, 1456)

total events C1: $38.3 \quad$ (557/

1456)

C2: 21.9 (316/

1441)

[\%] weight gain, I1: $6.9 \quad(100 /$

total events 1456)

C1: $1.2 \quad(18 /$ 


\section{Appendix 9. Adverse events (IV)}

\begin{tabular}{|c|c|c|c|c|}
\hline Characteristic & Rosenstock 2006b & Stocker 2007 & Sutton 2002 & Yang 2002 \\
\hline & $\begin{array}{l}\text { I1: rosiglitazone max. } 8 \\
\mathrm{mg}+\text { sulfonyurea }+ \text { met- } \\
\text { formin until } 2000 \mathrm{mg} \\
\mathrm{C} 1 \text { : } \\
\text { insulin glargine max. } 10 \\
\mathrm{U}+\text { sulfonylurea + met- } \\
\text { formin max. } 2000 \mathrm{mg}\end{array}$ & $\begin{array}{l}\mathrm{I} 1: \text { rosiglitazone } 4 \mathrm{mg} \\
\mathrm{C} 1: \text { metformin } 1.7 \mathrm{~g}\end{array}$ & $\begin{array}{l}\text { I1: rosiglitazone } 8 \mathrm{mg} \\
\mathrm{C} 1 \text { : glyburide less than } \\
20 \mathrm{mg}\end{array}$ & $\begin{array}{l}\text { I1: rosiglitazone } 4 \mathrm{mg} \\
\mathrm{C} 1 \text { : placebo }\end{array}$ \\
\hline $\begin{array}{l}\text { [n] of participants who } \\
\text { died }\end{array}$ & ? & $\begin{array}{l}\text { I1: } 0 \\
\text { C1: } 0\end{array}$ & ? & $\begin{array}{l}\text { I1: none } \\
\text { C1: none }\end{array}$ \\
\hline [\%] adverse events & $\begin{array}{l}\text { I1: } 28.6(32 / 112) \\
\mathrm{C} 1: 6.7(7 / 105)\end{array}$ & ? & ? & ? \\
\hline $\begin{array}{l}{[\%] \text { serious adverse }} \\
\text { events }\end{array}$ & $\begin{array}{l}\text { I1: } 9.8(11 / 112) \\
\text { C1: } 4.8(5 / 105)\end{array}$ & ? & ? & ? \\
\hline $\begin{array}{l}{[\%] \text { drop-outs due to ad- }} \\
\text { verse events }\end{array}$ & $\begin{array}{l}\text { I1: } 8(9 / 112) \\
\text { C1: } 2(2 / 105)\end{array}$ & $\begin{array}{l}\text { I1: } 8.9(4 / 45) \\
\text { C1: } 14.9(7 / 47)\end{array}$ & $\begin{array}{l}\text { I1: } 8(8 / 104) \\
\text { C1: } 4(4 / 99)\end{array}$ & ? \\
\hline [\%] oedema & $\begin{array}{l}\text { I1: } 12.5(14 / 112) \\
\text { C1: } 0\end{array}$ & $\begin{array}{l}\mathrm{I} 1: 24.4(11 / 45) \\
\mathrm{C} 1: 0\end{array}$ & $\begin{array}{l}\text { I1: } 6.7(7 / 104) \\
\text { C1: } 1(1 / 99)\end{array}$ & ? \\
\hline haemoglobin [g/dl] & $?$ & $?$ & $?$ & $?$ \\
\hline
\end{tabular}


(Continued)

\begin{tabular}{|c|c|c|c|c|}
\hline body weight [kg] & $\begin{array}{l}\mathrm{I} 1:+3 \\
\mathrm{C} 1:+1.7\end{array}$ & $\begin{array}{l}\text { I1: } 1.6 \\
\text { C1: }-2.0\end{array}$ & $\begin{array}{l}\mathrm{I} 1:+5 \\
\mathrm{C} 1:+3.4\end{array}$ & $\begin{array}{l}\mathrm{I} 1:+3.0 \\
\mathrm{C} 1:-0.4\end{array}$ \\
\hline $\begin{array}{l}\text { body mass index (BMI) } \\
{[\mathrm{kg} / \mathrm{m} 2]}\end{array}$ & ? & ? & ? & $\begin{array}{l}\mathrm{I} 1:+1.2 \\
\mathrm{C} 1:-0.4\end{array}$ \\
\hline $\begin{array}{l}{[\%] \text { hypoglycaemic }} \\
\text { episodes }\end{array}$ & $\begin{array}{l}\text { I1: } 42(47 / 112) \\
\text { C1: } 55(57 / 104)\end{array}$ & $?$ & $\begin{array}{l}\text { I1: } 1.9(2 / 104) \\
\text { C1: } 7.1(7 / 99)\end{array}$ & ? \\
\hline $\begin{array}{l}{[\%] \quad \text { severe }} \\
\text { hypoglycaemic episodes }\end{array}$ & $\begin{array}{l}\text { I1: } 5.4(6 / 112) \\
\text { C1: } 2.9(3 / 104)\end{array}$ & ? & $\begin{array}{l}\text { I1: } 0 \\
\text { C1: } 3(3 / 99)\end{array}$ & ? \\
\hline Notes & $\begin{array}{l}\text { severe hypoglycemia = } \\
\text { plasma glucose }<36 \mathrm{mg} / \\
\mathrm{dl} \text { or prompt recovery } \\
\text { after oral carbohydrate, } \\
\text { intravenous glucose or } \\
\text { glucagon adminstration } \\
\text { nocturnal hypoglycemia } \\
=<50 \mathrm{mg} / \mathrm{dl} \text { : } \\
\text { I1: } 3 \text { events } \\
\mathrm{C} 1: 10 \text { events } \\
\text { safety was assessed in } \\
\text { the intent-to-treat (ITT) } \\
\text { population }\end{array}$ & .1 & $\begin{array}{l}\text { cardiac related adverse } \\
\text { events: } \\
\text { I1: } 15.4 \% \text {; } 1: 12.1 \% \\
\text { heart disorder: } \\
\text { I1: } 9 / 104 . ; \mathrm{C} 1: 5 / 99 \\
\text { cardiomegaly: } \\
\text { I1: } 5 / 104 . ; \mathrm{C} 1: 2 / 99 \\
\text { I1: } 1 / 104 \text { clinical heart } \\
\text { failure } \\
\text { I1:2/104 initiated di- } \\
\text { uretic therapy as a result } \\
\text { of a fluid related event } \\
\text { C1: } \\
\text { hypoglycaemia: } \\
3 \text { of } 7 \text { total hypogly- } \\
\text { caemic episodes }\end{array}$ & \\
\hline $\begin{array}{l}\text { Footnotes } \\
?=\text { unclear; I = interven }\end{array}$ & $\mathrm{C}=$ control $; \mathrm{AE}=$ adve & rse events & & \\
\hline
\end{tabular}

\section{Appendix 10. Primary outcomes}

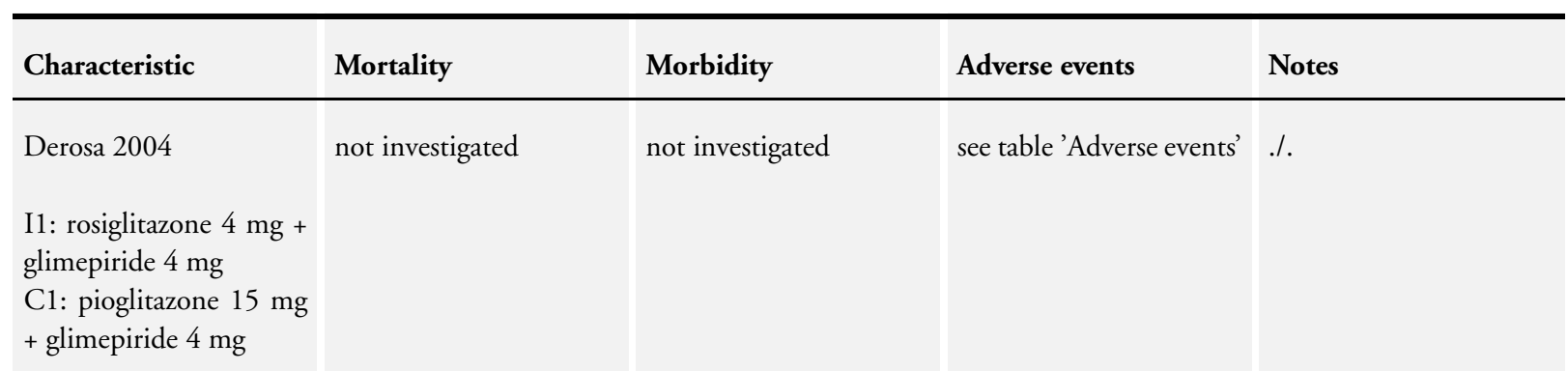




\begin{tabular}{|c|c|c|c|c|}
\hline $\begin{array}{l}\text { Derosa } 2006 \mathrm{a} \\
\text { I1: rosiglitazone } 4 \mathrm{mg}+ \\
\text { metformin } 3 \mathrm{~g} \\
\mathrm{C} 1 \text { : pioglitazone } 15 \mathrm{mg} \\
+ \text { metformin } 3 \mathrm{~g}\end{array}$ & not investigated & not investigated & see table 'Adverse events' &.$/$. \\
\hline $\begin{array}{l}\text { Derosa } 2006 \mathrm{~b} \\
\text { I1: rosiglitazone } 4 \mathrm{mg}+ \\
\text { metformin } 1.5 \mathrm{~g} \\
\mathrm{C} 1 \text { : glimepiride } 2 \mathrm{mg}+ \\
\text { metformin } 1.5 \mathrm{~g}\end{array}$ & not investigated & not investigated & see table 'Adverse events' &.$/$ \\
\hline $\begin{array}{l}\text { Garber } 2006 \\
\text { I1: rosiglitazone } 4 \mathrm{mg}+ \\
\text { metformin } 2 \mathrm{~g} \\
\mathrm{C} 1 \text { : glibenclamide } 5 \mathrm{mg} \\
+ \text { metformin } 1 \mathrm{~g}\end{array}$ & not investigated & not investigated & see table 'Adverse events' &.$/$. \\
\hline $\begin{array}{l}\text { Goldberg } 2005 \\
\text { I1: rosiglitazone } 8 \mathrm{mg} \\
\text { C1: pioglitazone } 45 \mathrm{mg}\end{array}$ & not investigated & not investigated & see table 'Adverse events' &.$/$ \\
\hline $\begin{array}{l}\text { Hällsten } 2002 \\
\text { I1: rosiglitazone } 8 \mathrm{mg} \\
\text { I2: metformin } 2 \mathrm{~g} \\
\text { C1: placebo }\end{array}$ & not investigated & not investigated & see table 'Adverse events' &.$/$. \\
\hline $\begin{array}{l}\text { Hanefeld } 2007 \\
\text { I1: rosiglitazone ( } 2 \mathrm{mg} \\
\text { bid) + placebo } \\
\text { I2: rosiglitazone ( } 4 \mathrm{mg} \\
\text { bid) + placebo } \\
\mathrm{C} 1 \text { : glibenclamide up to } \\
15 \mathrm{mg}+\text { placebo }\end{array}$ & not investigated & not investigated & see table 'Adverse events' &.$/$. \\
\hline $\begin{array}{l}\text { Jung } 2005 \\
\text { I1: rosiglitazone } 4 \mathrm{mg}+ \\
\text { glimepiride } 4 \mathrm{mg} \\
\mathrm{C} 1 \text { : metformin } 1 \mathrm{~g}+ \\
\text { glimepiride } 4 \mathrm{mg}\end{array}$ & not investigated & not investigated & see table 'Adverse events' &.$/$. \\
\hline
\end{tabular}


(Continued)

Kahn 2006

I1: rosiglitazone max. 8 $\mathrm{mg}$

C1: metformin max. $2 \mathrm{~g}$ C2: glyburide max. 15 $\mathrm{mg}$ death rates reported but morbidity rates reported see table 'Adverse events' ./. not part of the efficacy but not part of the efoutcomes, as defined in ficacy outcomes, as dethe publication of the fined in the publication study design (Diabetes of the study design (DiCare 2002): abetes Care 2002):

deaths from any cause cardiovascular disease [no]:

I1: 34

C1: 31

C2: 31

[no (\%)]:

serious / total events

I1: 49 (3.4) / $62(4.3)$

C1: $46(3.2) / 58(4.0)$
C2: $26(1.8) / 41(2.8)$

Peripheral vascular disease [no (\%)]:

serious / total events

I1: 7 (0.5) / $36(2.5)$

C1: $6(0.4) / 27$ (1.9)

C2: 4 (0.3) / $31(2.2)$

\section{Ko 2006}

not investigated

not investigated

see table 'Adverse events' ./.

I1: rosiglitazone max. 8

$\mathrm{mg}$

+ (sulfonylurea +/- met-

formin)

C1: "bedtime insulin"

+ (sulfonylurea +/- met-

formin)

Lebovitz 2001
I1: rosiglitazone $4 \mathrm{mg}$
I2: rosiglitazone $8 \mathrm{mg}$
C1: placebo

see table 'Adverse events' ./.

Ovalle 2004

not investigated

not investigated

see table 'Adverse events' ./.

I1: rosiglitazone $8 \mathrm{mg}$

I2: insulin (premixed 70/

30)

Philipps 2001
I1: rosiglitazone
4 mg o.d.; 2 mg b.i.d.; 8
mg o.d.; 4 mg b.i.d.
C1: placebo

Rosiglitazone for type 2 diabetes mellitus (Review)

not investigated not investigated

see table 'Adverse events' ./.

Copyright () 2009 The Cochrane Collaboration. Published by John Wiley \& Sons, Ltd. 
(Continued)

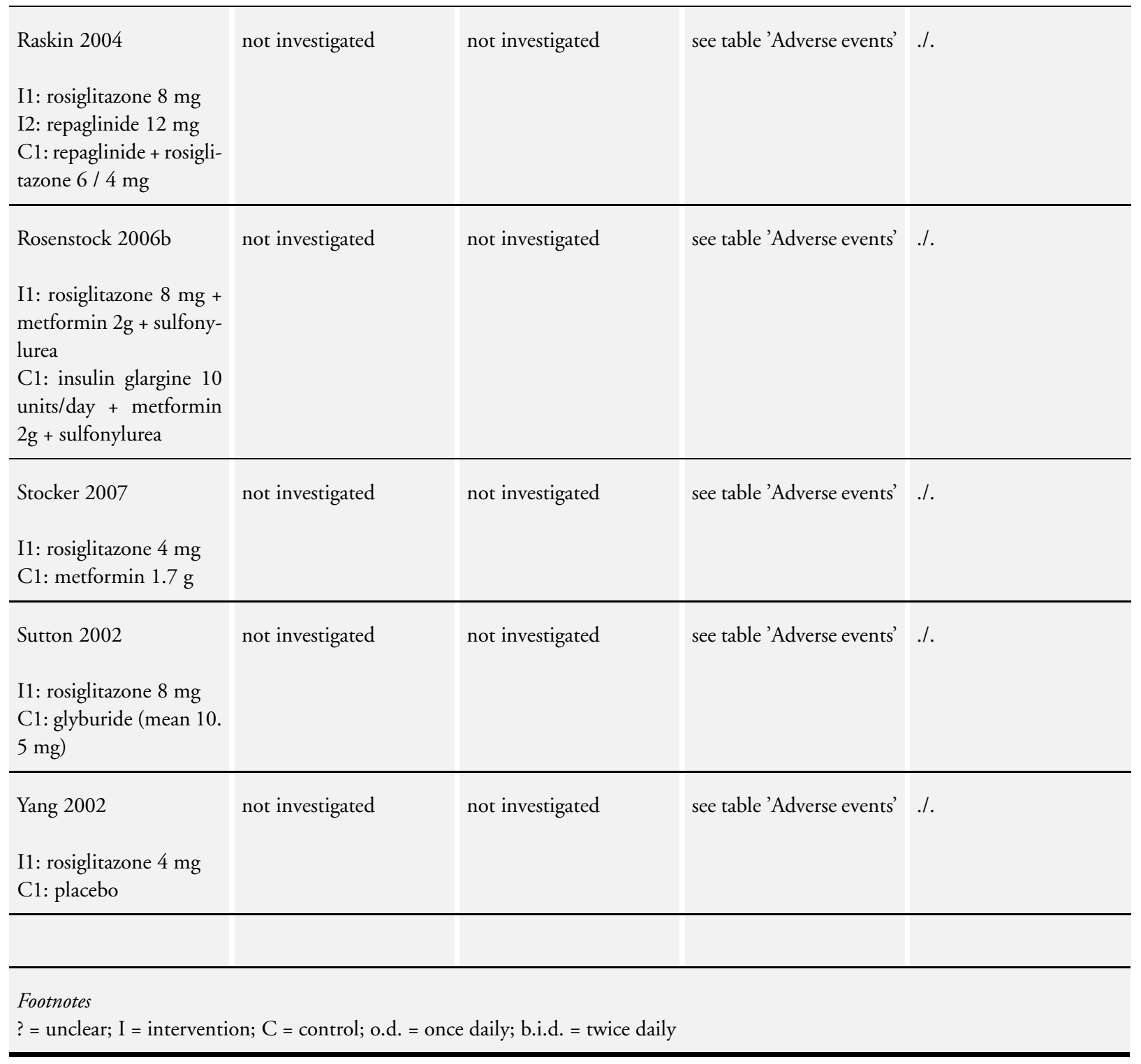

\section{Appendix II. Secondary outcomes}

\begin{tabular}{|c|c|c|c|c|}
\hline Characteristic & Quality of life & Costs & HbA1c [\%] (SD) & Notes \\
\hline $\begin{array}{l}\text { Derosa } 2004 \\
\text { I1: rosiglitazone } 4 \mathrm{mg}+ \\
\text { glimepiride } 4 \mathrm{mg}\end{array}$ & not investigated & not investigated & $\begin{array}{l}\text { I1: } \\
\text { end of study data: } 6.7(0 . \\
\text { 9) } \\
\text { change data: }\end{array}$ &.$/$. \\
\hline
\end{tabular}


$\mathrm{C} 1$ : pioglitazone $15 \mathrm{mg}$

+ glimepiride $4 \mathrm{mg}$
$\mathrm{C} 1$ :

end of study data: 6.8 (0.

8)

change data:

\begin{tabular}{|c|c|c|c|c|}
\hline $\begin{array}{l}\text { Derosa } 2006 \mathrm{a} \\
\text { I1: rosiglitazone } 4 \mathrm{mg}+ \\
\text { metformin } 3 \mathrm{~g} \\
\mathrm{C} 1 \text { : pioglitazone } 15 \mathrm{mg} \\
+ \text { metformin } 3 \mathrm{~g}\end{array}$ & not investigated & not investigated & $\begin{array}{l}\text { I1: } \\
\text { end of study data: } 6.8 \text { (0. } \\
\text { 5) } \\
\text { change data: }-1.3 \\
\mathrm{C} 1 \text { : } \\
\text { end of study data: } 6.8 \text { (0. } \\
\text { 3) } \\
\text { change data: }-1.4\end{array}$ & change data calculated \\
\hline
\end{tabular}

\section{Derosa 2006b}

not investigated

not investigated

I1: rosiglitazone $4 \mathrm{mg}+$ metformin $1.5 \mathrm{~g}$

$\mathrm{C1}$ : glimepiride $2 \mathrm{mg}+$ metformin $1.5 \mathrm{~g}$
I1:

end of study data: 6.8 (0.

6)

change data:

C1:

end of study data: 7.0 (0.

7)

change data:

I1: end of study data:

"change data" from abchange data: -1.1

$\mathrm{C} 1$ :

end of study data: change data: -1.5
$\mathrm{C} 1$ : glibenclamide $5 \mathrm{mg}$

+ metformin $1 \mathrm{~g}$ not investigated

Goldberg 2005

I1: rosiglitazone $8 \mathrm{mg}$

C1: pioglitazone $45 \mathrm{mg}$

\section{not investigated}

not investigated

I1:

end of study data:

change data: -0.6 (1.89)

$\mathrm{C} 1$ :

end of study data:

change data: -0.7 (1.91)
I1:

end of study data:

change data: -0.3

I2:

end of study data:

change data: -0.5

I1:

end of study data:

change data: -0.7

SDs calculated 


\begin{tabular}{|c|c|c|c|c|}
\hline $\begin{array}{l}\text { Hällsten } 2002 \\
\text { I1: rosiglitazone } 8 \mathrm{mg} \\
\text { I2: metformin } 2 \mathrm{~g} \\
\text { C1: placebo }\end{array}$ & not investigated & not investigated & $\begin{array}{l}\text { I1: } \\
\text { end of study data: } 6.5 \text { ( } 0 . \\
75) \\
\text { change data: } \\
\text { I2: } \\
\text { end of study data: } 6.2(0 . \\
72) \\
\text { change data: } \\
\text { C1: } \\
\text { end of study data: } 6.1(0 . \\
37) \\
\text { change data: }\end{array}$ & SDs calculated \\
\hline $\begin{array}{l}\text { Jung } 2005 \mathrm{I} 1 \text { : rosiglita- } \\
\text { zone } 4 \mathrm{mg}+\text { glimepiride } \\
4 \mathrm{mg} \mathrm{C1:} \mathrm{metformin} 1 \mathrm{~g} \\
\text { + glimepiride } 4 \mathrm{mg}\end{array}$ & not investigated & not investigated & $\begin{array}{l}\text { I1: } \\
\text { end of study data: } 7.8 \text { ( } 1 . \\
\text { 1) } \\
\text { change data: } \\
\mathrm{C} 1 \text { : } \\
\text { end of study data: } 8.0 \text { (1. } \\
\text { 1) } \\
\text { change data: }\end{array}$ &. \\
\hline $\begin{array}{l}\text { Kahn } 2006 \\
\text { I1: rosiglitazone max. } 8 \\
\text { mg } \\
\text { C1: metformin max. } 2 \mathrm{~g} \\
\text { C2: glyburide max. } 15 \\
\text { mg }\end{array}$ & $\begin{array}{l}\text { not yet reported but } \\
\text { mentioned in the pub- } \\
\text { lication of the study } \\
\text { design (Diabetes Care } \\
\text { 2002) }\end{array}$ & $\begin{array}{l}\text { not yet reported but } \\
\text { mentioned in the pub- } \\
\text { lication of the study } \\
\text { design (Diabetes Care } \\
\text { 2002) }\end{array}$ & $\begin{array}{l}\text { I1: } \\
\text { end of study data: } 7.1 \\
\text { change data: } \\
\text { C1: } \\
\text { end of study data: } 7.3 \\
\text { change data: } \\
\text { C2: } \\
\text { end of study data: } 7.4 \\
\text { change data: }\end{array}$ & $\begin{array}{l}\text { estimated from graph } \\
\text { (four year data) }\end{array}$ \\
\hline $\begin{array}{l}\text { Ko } 2006 \\
\text { I1: rosiglitazone max. } 8 \\
\text { mg } \\
+ \text { (sulfonylurea }+/ \text { - met- } \\
\text { formin) } \\
\text { C1: "bedtime insulin" } \\
+ \text { (sulfonylurea }+/ \text { - met- } \\
\text { formin) }\end{array}$ & not investigated & not investigated & $\begin{array}{l}\text { I1: } \\
\text { end of study data: } 9.1 \text { (2. } \\
0) \\
\text { change data: }-1.1(1.7) \\
\text { C1: } \\
\text { end of study data: } 8.3(1 . \\
\text { 3) } \\
\text { change data: }-1.3(1.6)\end{array}$ &.$/$. \\
\hline $\begin{array}{l}\text { Lebovitz } 2001 \\
\text { I1: rosiglitazone } 4 \mathrm{mg} \\
\text { I2: rosiglitazone } 8 \mathrm{mg} \\
\mathrm{C} 1 \text { : placebo }\end{array}$ & not investigated & not investigated & $\begin{array}{l}\text { I1: } \\
\text { end of study data: } \\
\text { change data: }-0.3 \\
\text { I2: } \\
\text { end of study data } \\
\text { change data: }-0.6\end{array}$ &. \\
\hline
\end{tabular}


C1:

end of study data:

change data: +0.9

Ovalle 2004
I1: rosiglitazone $8 \mathrm{mg}$
$\mathrm{C} 1$ : insulin (premixed
70/30)

not investigated not investigated

I1: $\quad . /$

end of study data: 7.8 ( 0 .

5)

change data:

C1:

end of study data: 7.8 ( 0 .

3)

change data:

\begin{tabular}{|c|c|c|c|c|}
\hline $\begin{array}{l}\text { Philipps } 2001 \\
\text { I1: rosiglitazone } \\
4 \text { mg o.d.; } 2 \text { mg b.i.d.; } 8 \\
\text { mg o.d.; } 4 \text { mg b.i.d. } \\
\text { C1: placebo }\end{array}$ & not investigated & not investigated & $\begin{array}{l}\text { pa- } \\
\text { tients who had received } \\
\text { prior oral monotherapy: } \\
\text { I1: } \\
\text { end of study data: } \\
\text { change data: } 4 \mathrm{mg} \text { o.d. } \\
(+0.14) ; 2 \mathrm{mg} \text { b.i.d. }(+0 \text {. } \\
02) ; 8 \mathrm{mg} \text { o.d. }(-0.26) ; 4 \\
\text { mg b.i.d. }(-0.54) \\
\text { C1: } \\
\text { end of study data: } \\
\text { change data: }+0.98\end{array}$ & SDs calculated \\
\hline $\begin{array}{l}\text { Raskin } 2004 \\
\text { I1: rosiglitazone } 8 \mathrm{mg} \\
\text { I2: repaglinide } 12 \mathrm{mg} \\
\mathrm{C} 1 \text { : repaglinide + rosigli- } \\
\text { tazone } 6 \mathrm{mg} / 4 \mathrm{mg}\end{array}$ & not investigated & not investigated & $\begin{array}{l}\text { I1: } \\
\text { end of study data: } 8.5 \\
\text { change data: }-0.56(1.0) \\
\text { I2: } \\
\text { end of study data: } 9.1 \\
\text { change data: }-0.17(1.1) \\
\text { C2: } \\
\text { end of study data: } 7.7 \\
\text { change data: }-1.43(1.1)\end{array}$ & SDs calculated \\
\hline $\begin{array}{l}\text { Rosenstock } 2006 \mathrm{~b} \\
\mathrm{I} 1 \text { : rosiglitazone } 8 \mathrm{mg}+ \\
\text { metformin } 2 \mathrm{~g}+\text { sulfony- } \\
\text { lurea } \\
\mathrm{C} 1 \text { : insulin glargine } 10 \\
\text { units/day + metformin } \\
2 \mathrm{~g}+\text { sulfonylurea }\end{array}$ & not investigated & $\begin{array}{l}\mathrm{I} 1: \$ 1,603 \\
\mathrm{C} 1: \$ 1,368\end{array}$ & $\begin{array}{l}\text { I1: } \\
\text { end of study data: } \\
\text { change data: }-1.51 \\
\mathrm{C} 1 \text { : } \\
\text { end of study data: } \\
\text { change data: }-1.66\end{array}$ &. \\
\hline $\begin{array}{l}\text { Stocker } 2007 \\
\text { I1: rosiglitazone } 4 \mathrm{mg} \\
\mathrm{C} 1 \text { : metformin } 1.7 \mathrm{~g}\end{array}$ & not investigated & not investigated & $\begin{array}{l}\text { I1: } \\
\text { end of study data: } \\
\text { change data: }-1.08(0 . \\
\text { 14) }\end{array}$ & $(\mathrm{SE}$ or $\mathrm{SD})$ ? \\
\hline
\end{tabular}


$\mathrm{C} 1$ :

end of study data:

change data: $-1.19(0$.

13)

\begin{tabular}{|c|c|c|c|c|}
\hline $\begin{array}{l}\text { Sutton } 2002 \\
\text { I1: rosiglitazone } 8 \mathrm{mg} \\
\mathrm{C} 1 \text { : glyburide (mean } 10 . \\
5 \mathrm{mg} \text { ) }\end{array}$ & not investigated & not investigated & $\begin{array}{l}\text { I1: } \\
\text { end of study data: } 8.1(0 . \\
\text { 3) } \\
\text { change data: } \\
\mathrm{C} 1 \text { : } \\
\text { end of study data: } 8.4(0 . \\
\text { 2) } \\
\text { change data: }\end{array}$ &.$/$ \\
\hline $\begin{array}{l}\text { Yang } 2002 \\
\mathrm{I} 1 \text { : rosiglitazone } 4 \mathrm{mg} \\
\mathrm{C} 1 \text { : placebo }\end{array}$ & not investigated & not investigated & $\begin{array}{l}\text { I1: } \\
\text { end of study data: } \\
\text { change data: }-0.7(1.04) \\
\mathrm{C} 1 \text { : } \\
\text { end of study data: } \\
\text { change data: } 0.4(1.3)\end{array}$ &. \\
\hline
\end{tabular}

Footnotes

? = unclear; $\mathrm{I}$ = intervention; $\mathrm{C}$ = control; o.d. = once daily; b.i.d. = twice daily

\section{Appendix 12. Changes to the published protocol}

\section{Changed items}

The following changes to the published protocol with regards to 'types of intervention' were implemented:

The following comparisons were acceptable for evaluation:

- rosiglitazone versus placebo;

- rosiglitazone versus another oral antidiabetic medication (meglitinide analogues, metformin, pioglitazone, sulphonylureas);

- rosiglitazone in combination with an oral antidiabetic medication or insulin versus a combination of an oral antidiabetic medication or insulin (agents and treatment schemes had to be identical).

Excluded interventions:

Combination therapies consisting of different compounds in the treatment arms (for example rosiglitazone plus metformin versus uptitration of metformin or rosiglitazone plus gliclazide versus gliclazide). Another Cochrane review will investigate rosiglitazonemetformin combination therapies including different treatment regimens of these compounds. Furthermore, dipeptidyl peptidase- 4 (DPP-4) inhibitors for type 2 diabetes mellitus are excluded, since these are the topic of another Cochrane review (Richter 2007), as well as glucagon-like peptide analogues for type 2 diabetes mellitus (Cochrane review, Snaith 2007) 
Appendix 13. Risk of bias (I)

\begin{tabular}{|c|c|c|c|}
\hline Characteristic & Derosa 2004 & Derosa 2006a & Derosa 2006b \\
\hline $\begin{array}{l}\text { Intervention } 1 \text { (I1) / interven- } \\
\text { tion } 2 \text { (I2) / control } 1(\mathrm{C} 1)\end{array}$ & $\begin{array}{l}\text { I1: rosiglitazone + glimepiride } \\
\mathrm{C} 1 \text { : pioglitazone + glimepiride }\end{array}$ & $\begin{array}{l}\text { I1: rosiglitazone + metformin } \\
\text { C1: pioglitazone + metformin }\end{array}$ & $\begin{array}{l}\text { I1: rosiglitazone + metformin } \\
\mathrm{C} 1 \text { : glimepiride + metformin }\end{array}$ \\
\hline $\begin{array}{l}\text { Randomised controlled clinical } \\
\text { trial (RCT) }\end{array}$ & $\mathrm{Y}$ & Y & $\mathrm{Y}$ \\
\hline $\begin{array}{l}\text { Non-inferiority / equivalence } \\
\text { trial }\end{array}$ & $\mathrm{N}$ & $\mathrm{N}$ & $\mathrm{N}$ \\
\hline Controlled clinical trial & $\mathrm{N}$ & $\mathrm{N}$ & $\mathrm{N}$ \\
\hline Design: parallel study & $\mathrm{Y}$ & $\mathrm{Y}$ & Y \\
\hline Design: crossover study & $\mathrm{N}$ & $\mathrm{N}$ & $\mathrm{N}$ \\
\hline Design: factorial study & $\mathrm{N}$ & $\mathrm{N}$ & $\mathrm{N}$ \\
\hline $\begin{array}{l}\text { Crossover study: wash-out } \\
\text { phase }\end{array}$ & NA & NA & NA \\
\hline $\begin{array}{l}\text { Crossover study: carryover ef- } \\
\text { fect tested }\end{array}$ & NA & NA & NA \\
\hline $\begin{array}{l}\text { Crossover study: period effect } \\
\text { tested }\end{array}$ & NA & NA & NA \\
\hline Method of randomisation & $\begin{array}{l}\text { randomisation codes prepared } \\
\text { by statistician }\end{array}$ & ? & $\begin{array}{l}\text { drawing of envelopes; randomi- } \\
\text { sation codes prepared by a } \\
\text { statistician }\end{array}$ \\
\hline $\begin{array}{l}\text { Unit of randomisation (individ- } \\
\text { uals, cluster - specify) }\end{array}$ & individuals & ? & individuals \\
\hline $\begin{array}{l}\text { Randomisation stratified for } \\
\text { centres }\end{array}$ & ? & ? & ? \\
\hline Randomisation ratio & $1: 1$ & $1: 1$ & $1: 1$ \\
\hline Concealment of allocation & $\begin{array}{l}\text { envelopes; a copy of the ran- } \\
\text { domisation code was provided } \\
\text { only to the statistician }\end{array}$ & $\begin{array}{l}\text { envelopes containing randomi- } \\
\text { sation code; a copy of the ran- } \\
\text { domisation code was provoided } \\
\text { only for the statistician }\end{array}$ & ?; drawing of envelopes \\
\hline $\begin{array}{l}\text { Stated blinding (open; single, } \\
\text { double, triple blind) }\end{array}$ & double-blind & double-blind & double-blind \\
\hline
\end{tabular}




\begin{tabular}{|c|c|c|c|}
\hline Actual blinding: participant & Y & Y & Y \\
\hline $\begin{array}{l}\text { Actual blinding: caregiver / } \\
\text { treatment administrator }\end{array}$ & ? & ? & ? \\
\hline $\begin{array}{l}\text { Actual blinding: outcome asses- } \\
\text { sor }\end{array}$ & $?$ & ? & ? \\
\hline Actual blinding: others & $?$ & $?$ & $?$ \\
\hline Blinding checked: participant & $\mathrm{N}$ & $\mathrm{N}$ & $\mathrm{N}$ \\
\hline $\begin{array}{l}\text { Blinding checked: caregiver / } \\
\text { treatment administrator }\end{array}$ & $\mathrm{N}$ & $\mathrm{N}$ & $\mathrm{N}$ \\
\hline $\begin{array}{l}\text { Primary endpoint defined } \\
\text { (power calculation) }\end{array}$ & $\mathrm{N}$ & $\mathrm{N}$ & Y \\
\hline [n] of primary endpoint(s) & 6 & 5 & 5 \\
\hline [n] of secondary endpoints & $?$ & ? & 6 \\
\hline Total [n] of endpoints & $?$ & ? & 11 \\
\hline $\begin{array}{l}\text { Prior publication of study de- } \\
\text { sign }\end{array}$ & $\mathrm{N}$ & $?$ & $\mathrm{~N}$ \\
\hline $\begin{array}{l}\text { Outcomes of prior/current } \\
\text { publication identical }\end{array}$ & NA & $\mathrm{N}$ & $\mathrm{N}$ \\
\hline Power calculation & $\mathrm{N}$ & $\mathrm{N}$ & ?; see notes for details \\
\hline $\begin{array}{l}\text { [n] participants per group cal- } \\
\text { culated }\end{array}$ & NA & NA & ?; stated but no details provided \\
\hline $\begin{array}{l}\text { Non-inferiority trial: interval } \\
\text { for equivalence specified }\end{array}$ & NA & NA & NA \\
\hline $\begin{array}{l}\text { Intention-to-treat analysis } \\
\text { (ITT) }\end{array}$ & Y & $\mathrm{Y}$ & $\mathrm{Y}$ \\
\hline Per-protocol-analysis & $\mathrm{N}$ & $\mathrm{N}$ & $\mathrm{N}$ \\
\hline ITT defined & Y & Y & Y \\
\hline $\begin{array}{l}\text { Missing data: last observation } \\
\text { carried forward (LOCF) }\end{array}$ & $?$ & $?$ & $\mathrm{~N}$ \\
\hline
\end{tabular}


(Continued)

\begin{tabular}{|c|c|c|c|}
\hline Missing data: Other methods & $\begin{array}{l}\text { Y } \\
\text { Bonferroni }\end{array}$ & $\begin{array}{l}\text { Y } \\
\text { Bonferroni }\end{array}$ & $\mathrm{N}$ \\
\hline LOCF defined & NA & NA & $\mathrm{N}$ \\
\hline Analysis stratified for centres & $\mathrm{N}$ & ? & $\mathrm{N}$ \\
\hline $\begin{array}{l}\text { [n] of screened patients (I1 / I2/ } \\
\mathrm{C} 1 / \text { total) }\end{array}$ & ? & ? & ? \\
\hline $\begin{array}{l}\text { [n] of randomised participants } \\
\text { (I1/ I2 / C1 / total) - primary } \\
\text { endpoint }\end{array}$ & $\begin{array}{l}\text { I1: } 42 \text { (baseline) } \\
\text { C1: } 45 \text { (baseline) } \\
\text { total: } 91\end{array}$ & $\begin{array}{l}\text { I1: } 48 \text { (baseline) } \\
\text { C1: } 48 \text { (baseline) } \\
\text { total: } 103\end{array}$ & $\begin{array}{l}\text { I1: } 48 \text { (baseline) } \\
\text { C1: } 47 \text { (baseline) } \\
\text { total: } 99\end{array}$ \\
\hline $\begin{array}{l}\text { [n] of participants finishing the } \\
\text { study (I1/ I } 2 \text { / C1 / total) }\end{array}$ & $\begin{array}{l}\text { I1: } 42 \\
\text { C1: } 45 \\
\text { total: } 87\end{array}$ & $\begin{array}{l}\text { I1: } 48 \\
\text { C1:48 } \\
\text { total: } 96\end{array}$ & $\begin{array}{l}\text { I1: } 48 \text { (baseline) } \\
\text { C1: } 47 \text { (baseline) } \\
\text { total: } 95\end{array}$ \\
\hline $\begin{array}{l}\text { [n] of participants analysed (I1/ } \\
\text { I } 2 \text { / C } 1 / \text { total) - primary end- } \\
\text { point }\end{array}$ & $\begin{array}{l}\text { I1: } 42 \\
\text { C1: } 45 \\
\text { total: } 87\end{array}$ & $\begin{array}{l}\text { I1: } 48 \\
\text { C1:48 } \\
\text { total: } 96\end{array}$ & ? \\
\hline $\begin{array}{l}\text { Description of discontinuing } \\
\text { participants }\end{array}$ & $\mathrm{N}$ & $\mathrm{N}$ & $\mathrm{N}$ \\
\hline Drop-outs (reasons explained) & $\mathrm{Y}$ & $\mathrm{N}$ & $\mathrm{N}$ \\
\hline $\begin{array}{l}\text { Withdrawals } \quad \text { (reasons } \\
\text { explained) }\end{array}$ & Y & $\mathrm{N}$ & Y \\
\hline $\begin{array}{l}\text { Losses-to-follow-up (reasons } \\
\text { explained) }\end{array}$ & $\mathrm{N}$ & $\mathrm{N}$ & $\mathrm{N}$ \\
\hline $\begin{array}{l}\text { [n] of participants who discon- } \\
\text { tinued (I1/ I } 2 \text { / C1 / total) }\end{array}$ & $\begin{array}{l}\text { I1: } 2 \\
\text { C1: } 2 \\
\text { total: } 4\end{array}$ & $\begin{array}{l}\text { I1: ? } \\
\text { C1: ? } \\
\text { total: } 7\end{array}$ & $\begin{array}{l}\text { I1: } 2 \\
\text { C1: } 2 \\
\text { total: } 4\end{array}$ \\
\hline $\begin{array}{l}\text { [\%] discontinuation rate }(\mathrm{I} 1 / \mathrm{I} 2 \\
\text { / C1 / total) }\end{array}$ & $\begin{array}{l}\text { I1: } 5 \\
\text { C1: } 4 \\
\text { total: } 4\end{array}$ & $\begin{array}{l}\text { I1: ? } \\
\text { C1: ? } \\
\text { total: } 6\end{array}$ & $\begin{array}{l}\text { I1: ? } \\
\text { C1: ? } \\
\text { total: } 4\end{array}$ \\
\hline $\begin{array}{l}\text { Discontinuation rate similar } \\
\text { between groups }\end{array}$ & Y & $?$ & Y \\
\hline [\%] crossover between groups & $?$ & $?$ & $?$ \\
\hline $\begin{array}{l}\text { Differences [n] calculated to } \\
\text { analysed patients }\end{array}$ & NA & ? & ? \\
\hline
\end{tabular}




\begin{tabular}{|c|c|c|c|}
\hline $\begin{array}{l}\text { Adjustment for multiple out- } \\
\text { comes / repeated measurements }\end{array}$ & $\mathrm{Y}$ & see comments & $\mathrm{N}$ \\
\hline $\begin{array}{l}\text { Baseline characteristics: Clini- } \\
\text { cally relevant differences }\end{array}$ & $\mathrm{N}$ & $\mathrm{N}$ & $\mathrm{N}$ \\
\hline $\begin{array}{l}\text { Treatment identical (apart from } \\
\text { intervention) }\end{array}$ & $\begin{array}{l}\mathrm{N} \\
\text { some patients received be- } \\
\text { haviour modification, sessions } \\
\text { for weight-loss }\end{array}$ & $\mathrm{Y}$ & Y \\
\hline Compliance measured & $\begin{array}{l}\text { Y } \\
\text { pill count }\end{array}$ & $\begin{array}{l}\text { Y } \\
\text { pill count }\end{array}$ & $\begin{array}{l}\text { Y } \\
\text { pill count }\end{array}$ \\
\hline $\begin{array}{l}\text { Other important covariates } \\
\text { measured (specify) }\end{array}$ & $\mathrm{N}$ & $\mathrm{N}$ & $\mathrm{N}$ \\
\hline Co-morbidities measured & $\mathrm{N}$ & $\mathrm{N}$ & $\mathrm{N}$ \\
\hline Co-medications measured & $\mathrm{Y}$ & $\mathrm{N}$ & $\mathrm{Y}$ \\
\hline $\begin{array}{l}\text { Specific doubts about study } \\
\text { quality }\end{array}$ & $\begin{array}{l}\mathrm{Y} \\
\text { see notes }\end{array}$ & $\begin{array}{l}\text { Y } \\
\text { see notes }\end{array}$ & ? \\
\hline Funding: commercial & ? & $\mathrm{N}$ & ? \\
\hline Funding: non-commercial & ? & $\mathrm{N}$ & ? \\
\hline $\begin{array}{l}\text { Publication status: peer review } \\
\text { journal }\end{array}$ & $\mathrm{Y}$ & $\mathrm{Y}$ & $\mathrm{Y}$ \\
\hline $\begin{array}{l}\text { Publication status: journal sup- } \\
\text { plement }\end{array}$ & $\mathrm{N}$ & $\mathrm{N}$ & $\mathrm{N}$ \\
\hline Publication status: abstract & $\mathrm{N}$ & $\mathrm{N}$ & $\mathrm{N}$ \\
\hline Publication status: other & $\mathrm{N}$ & $\mathrm{N}$ & $\mathrm{N}$ \\
\hline Notes & $\begin{array}{l}\text { patients were re- } \\
\text { quested to follow a controlled- } \\
\text { energy diet (ADA); some pa- } \\
\text { tients received behaviour mod- } \\
\text { ifications for weight-loss; ex- } \\
\text { ercise recommendations were } \\
\text { given; co-medications not spec- } \\
\text { ified for intervention vs control }\end{array}$ & $\begin{array}{l}\text { patients re- } \\
\text { quested to follow a controlled- } \\
\text { energy diet (ADA); patients re- } \\
\text { ceived behaviour modifications } \\
\text { for weight-loss; exercise recom- } \\
\text { mendations were given; adjust- } \\
\text { ment stated as Bonferroni but } \\
\text { P-values provided show no in- } \\
\text { dication of application of the } \\
\text { method; drop-outs per group }\end{array}$ & $\begin{array}{l}\text { pa- } \\
\text { tients were requested to follow } \\
\text { a controlled-energy diet (ADA) } \\
\text {; all patients received behaviour } \\
\text { modifications for weight-loss; } \\
\text { exercise recommendations were } \\
\text { given; co-medication not spec- } \\
\text { ified for intervention vs con- } \\
\text { trol; publication in Pharma- } \\
\text { cotherapy } 2005 \text { states that a }\end{array}$ \\
\hline
\end{tabular}


$\mathrm{Y}=$ yes; $\mathrm{N}=$ no; ? = unclear $\mathrm{I}$ = intervention; $\mathrm{C}$ = control; (baseline) = if numbers for certain features could ne be derived from the text, numbers from baseline characteristics were used

\section{Appendix I4. Risk of bias (II)}

\begin{tabular}{|c|c|c|c|c|c|}
\hline Characteristic & Garber 2006 & Goldberg 2005 & Hanefeld 2007 & Hällsten 2002 & Jung 2005 \\
\hline $\begin{array}{l}\text { Intervention } 1 \text { (I1) / } \\
\text { intervention } 2 \text { (I2) / } \\
\text { control } 1 \text { (C1) }\end{array}$ & $\begin{array}{l}\text { I1: rosiglitazone + } \\
\text { metformin } \\
\text { C1: glibenclamide + } \\
\text { metformin }\end{array}$ & $\begin{array}{l}\text { I1: pioglitazone } \\
\mathrm{C} 1 \text { : rosiglitazone }\end{array}$ & $\begin{array}{l}\text { I1: rosiglitazone } 4 \\
\mathrm{mg}+\text { placebo } \\
\text { I2: rosiglitazone } 8 \\
\mathrm{mg}+\text { placebo } \\
\mathrm{C} 1 \text { : glibenclamide + } \\
\text { placebo }\end{array}$ & $\begin{array}{l}\text { I1: rosiglitazone } \\
\text { I2: metformin } \\
\text { C1: placebo }\end{array}$ & $\begin{array}{l}\text { I1: rosiglitazone + } \\
\text { glimipiride } \\
\mathrm{C} 1 \text { : metformin + } \\
\text { glimipiride }\end{array}$ \\
\hline $\begin{array}{l}\text { Randomised con- } \\
\text { trolled clinical trial } \\
\text { (RCT) }\end{array}$ & $\mathrm{Y}$ & Y & Y & Y & Y \\
\hline $\begin{array}{l}\text { Non-inferiority / } \\
\text { equivalence trial }\end{array}$ & $\mathrm{N}$ & $\mathrm{N}$ & Y & $\mathrm{N}$ & $\mathrm{N}$ \\
\hline $\begin{array}{l}\text { Controlled clinical } \\
\text { trial }\end{array}$ & $\mathrm{N}$ & $\mathrm{N}$ & $\mathrm{N}$ & $\mathrm{N}$ & $\mathrm{N}$ \\
\hline $\begin{array}{l}\text { Design: parallel } \\
\text { study }\end{array}$ & Y & Y & Y & Y & $\mathrm{Y}$ \\
\hline $\begin{array}{l}\text { Design: crossover } \\
\text { study }\end{array}$ & $\mathrm{N}$ & $\mathrm{N}$ & $\mathrm{N}$ & $\mathrm{N}$ & $\mathrm{N}$ \\
\hline $\begin{array}{l}\text { Design: factorial } \\
\text { study }\end{array}$ & $\mathrm{N}$ & $\mathrm{N}$ & $\mathrm{N}$ & $\mathrm{N}$ & $\mathrm{N}$ \\
\hline $\begin{array}{l}\text { Crossover study: } \\
\text { wash-out phase }\end{array}$ & NA & NA & NA & NA & NA \\
\hline
\end{tabular}




\begin{tabular}{|c|c|c|c|c|c|}
\hline $\begin{array}{l}\text { Crossover } \\
\text { study: carryover ef- } \\
\text { fect tested }\end{array}$ & NA & NA & NA & NA & NA \\
\hline $\begin{array}{l}\text { Crossover study: pe- } \\
\text { riod effect tested }\end{array}$ & NA & NA & NA & NA & NA \\
\hline $\begin{array}{l}\text { Method of } \\
\text { randomisation }\end{array}$ & $?$ & $\begin{array}{l}\text { stratified } \\
\text { for being previously } \\
\text { treated with oral an- } \\
\text { tidiabetic drugs and } \\
\text { according to sex }\end{array}$ & ? & ? & ? \\
\hline $\begin{array}{l}\text { Unit of randomi- } \\
\text { sation (individuals, } \\
\text { cluster - specify) }\end{array}$ & individuals & individuals & individuals & individuals & individuals \\
\hline $\begin{array}{l}\text { Randomisation } \\
\text { stratified for centres }\end{array}$ & $?$ & $\mathrm{~N}$ & ? & ? & ? \\
\hline $\begin{array}{l}\text { Randomisation ra- } \\
\text { tio }\end{array}$ & $1: 1$ & $1: 1$ & $1: 1: 1$ & $1: 1$ & $1: 1$ \\
\hline $\begin{array}{l}\text { Concealment of al- } \\
\text { location }\end{array}$ & $?$ & ? & ? & ? & ? \\
\hline $\begin{array}{l}\text { Stated blinding } \\
\text { (open; single, dou- } \\
\text { ble, triple blind) }\end{array}$ & double-blind & double-blind & $\begin{array}{l}\text { double-blind, dou- } \\
\text { ble-dummy }\end{array}$ & double-blind & ? \\
\hline $\begin{array}{l}\text { Actual blinding: } \\
\text { participant }\end{array}$ & Y & ? & Y & $\mathrm{Y}$ & NA \\
\hline $\begin{array}{l}\text { Actual blind- } \\
\text { ing: caregiver / treat- } \\
\text { ment administrator }\end{array}$ & ? & ? & ? & $?$ & NA \\
\hline $\begin{array}{l}\text { Actual blinding: } \\
\text { outcome assessor }\end{array}$ & $?$ & ? & $?$ & ? & NA \\
\hline $\begin{array}{l}\text { Actual blinding: } \\
\text { others }\end{array}$ & $?$ & ? & ? & ? & NA \\
\hline $\begin{array}{l}\text { Blinding checked: } \\
\text { participant }\end{array}$ & $\mathrm{N}$ & $\mathrm{N}$ & $\mathrm{N}$ & $\mathrm{N}$ & NA \\
\hline $\begin{array}{l}\text { Blinding } \\
\text { checked: caregiver / } \\
\text { treatment adminis- }\end{array}$ & $\mathrm{N}$ & $\mathrm{N}$ & $\mathrm{N}$ & $\mathrm{N}$ & NA \\
\hline
\end{tabular}




\begin{tabular}{|c|c|c|c|c|c|}
\hline $\begin{array}{l}\text { Primary endpoint } \\
\text { defined (power cal- } \\
\text { culation) }\end{array}$ & $\mathrm{Y}$ & $\mathrm{Y}$ & Y & $\mathrm{N}$ & $\mathrm{N}$ \\
\hline $\begin{array}{l}\text { [n] of primary end- } \\
\text { point }(s)\end{array}$ & 1 & 1 & 1 & ? & ? \\
\hline $\begin{array}{l}\text { [n] of secondary } \\
\text { endpoints }\end{array}$ & 7 & 16 & 13 & ? & ? \\
\hline $\begin{array}{l}\text { Total [n] of end- } \\
\text { points }\end{array}$ & 8 & 17 & 14 & 13 & 10 \\
\hline $\begin{array}{l}\text { Prior publication of } \\
\text { study design }\end{array}$ & $\mathrm{N}$ & $\mathrm{N}$ & $\mathrm{N}$ & $\mathrm{N}$ & $\mathrm{N}$ \\
\hline $\begin{array}{l}\text { Outcomes of prior/ } \\
\text { current publication } \\
\text { identical }\end{array}$ & NA & NA & NA & NA & NA \\
\hline Power calculation & $\mathrm{Y}$ & $\mathrm{N}$ & Y & $\mathrm{N}$ & $\mathrm{N}$ \\
\hline $\begin{array}{l}\text { [n] participants per } \\
\text { group calculated }\end{array}$ & 150 & NA & ? & NA & NA \\
\hline $\begin{array}{l}\text { Non-in- } \\
\text { feriority trial: inter- } \\
\text { val for equivalence } \\
\text { specified }\end{array}$ & NA & NA & $\mathrm{Y}$ & NA & NA \\
\hline $\begin{array}{l}\text { Intention-to-treat } \\
\text { analysis (ITT) }\end{array}$ & Y & Y & Y & ? & ? \\
\hline $\begin{array}{l}\text { Per-protocol- } \\
\text { analysis }\end{array}$ & $\mathrm{N}$ & $\mathrm{Y}$ & $?$ & ? & $?$ \\
\hline ITT defined & $\mathrm{Y}$ & Y & Y & NA & NA \\
\hline $\begin{array}{l}\text { Missing data: last } \\
\text { observation carried } \\
\text { forward (LOCF) }\end{array}$ & $?$ & $\mathrm{Y}$ & Y & $\mathrm{N}$ & $\mathrm{N}$ \\
\hline $\begin{array}{l}\text { Missing data: Other } \\
\text { methods }\end{array}$ & $\mathrm{N}$ & $\mathrm{N}$ & $\mathrm{N}$ & $\mathrm{N}$ & $\mathrm{N}$ \\
\hline LOCF defined & NA & $\mathrm{N}$ & $\mathrm{N}$ & NA & NA \\
\hline
\end{tabular}




\begin{tabular}{|c|c|c|c|c|c|}
\hline $\begin{array}{l}\text { Analysis stratified } \\
\text { for centres }\end{array}$ & $\mathrm{N}$ & $\mathrm{N}$ & ? & $\mathrm{N}$ & $\mathrm{N}$ \\
\hline $\begin{array}{l}{[\mathrm{n}] \text { of screened pa- }} \\
\text { tients }(\mathrm{I} 1 / \mathrm{I} 2 / \mathrm{C} 1 / \\
\text { total) }\end{array}$ & total: 356 & total: 4410 & total: 662 & ? & ? \\
\hline $\begin{array}{l}\text { [n] of randomised } \\
\text { participants (I1/ I } 2 \text { / } \\
\text { C1 / total) - primary } \\
\text { endpoint }\end{array}$ & $\begin{array}{l}\text { I1: } 158 \\
\text { C1: } 160 \\
\text { total: } 318\end{array}$ & $\begin{array}{l}\text { I1: } 369 ; \\
\text { C1: } 366 ; \\
\text { total: } 735\end{array}$ & $\begin{array}{l}\text { I1: } 200 \\
\text { I2: } 191 \\
\text { C1: } 207 \\
\text { total: } 598\end{array}$ & $\begin{array}{l}\text { I1: } 15 \\
\text { I2: } 16 \\
\text { C1: } 14 \\
\text { total: } 45\end{array}$ & $\begin{array}{l}\text { I1: } 15 \\
\text { C1: } 15 \\
\text { total: } 30\end{array}$ \\
\hline $\begin{array}{l}\text { [n] of participants } \\
\text { finishing the study } \\
\text { (I1/ I } / \mathrm{C} 1 / \text { total) }\end{array}$ & $\begin{array}{l}\text { I1: } 133 \\
\text { C1: } 131 \\
\text { total: } 264\end{array}$ & $\begin{array}{l}\text { I1: } 299 \\
\text { C1: } 286 \\
\text { total: } 585\end{array}$ & $\begin{array}{l}\text { I1: } 153 \\
\text { I2: } 158 \\
\text { C1: } 173 \\
\text { total: } 484\end{array}$ & $\begin{array}{l}\text { I1: } 14 \\
\text { I2: } 13 \\
\text { C1: } 14 \\
\text { total: } 41\end{array}$ & $\begin{array}{l}\text { I1: } 14 \\
\text { C1: } 13 \\
\text { total: } 27\end{array}$ \\
\hline $\begin{array}{l}\text { [n] of participants } \\
\text { analysed (I1/ I } 2 \text { / } \\
\text { C1 / total) - primary } \\
\text { endpoint }\end{array}$ & $\begin{array}{l}\text { I1: } \\
\text { C1: } \\
\text { total: } 305\end{array}$ & $\begin{array}{l}\text { I1: } 363 \\
\text { C1: } 356 \\
\text { total: } 719\end{array}$ & $\begin{array}{l}\text { I1: } 195 \\
\text { I2: } 189 \\
\text { C1: } 202 \\
\text { total: } 586 \\
\text { (ITT population) }\end{array}$ & $\begin{array}{l}\text { I1: } 14 \\
\text { I2: } 13 \\
\text { C1: } 14 \\
\text { total: } 41\end{array}$ & $\begin{array}{l}\text { I1: } 14 \\
\text { C1: } 13 \\
\text { total: } 27\end{array}$ \\
\hline $\begin{array}{l}\text { Description of dis- } \\
\text { continuing partici- } \\
\text { pants }\end{array}$ & $\mathrm{N}$ & Y & Y & $\mathrm{N}$ & $\mathrm{N}$ \\
\hline $\begin{array}{l}\text { Drop-outs (reasons } \\
\text { explained) }\end{array}$ & Y & Y & ? & $\mathrm{N}$ & $\mathrm{Y}$ \\
\hline $\begin{array}{l}\text { Withdrawals } \\
\text { (reasons explained) }\end{array}$ & Y & Y & Y & Y & $\mathrm{N}$ \\
\hline $\begin{array}{l}\text { Losses-to-follow-up } \\
\text { (reasons explained) }\end{array}$ & $?$ & $\mathrm{Y}$ & ? & $\mathrm{N}$ & $\mathrm{N}$ \\
\hline $\begin{array}{l}\text { [n] } \\
\text { of participants who } \\
\text { discontinued (I1/ I2 } \\
\text { / C1 / total) }\end{array}$ & $\begin{array}{l}\text { I1: } 25 \\
\text { C1: } 29 \\
\text { total: } 54\end{array}$ & $\begin{array}{l}\text { I1: } 70 \\
\text { C1: } 80 \\
\text { total: } 150\end{array}$ & $\begin{array}{l}\text { I1: } 47 \\
\text { I2: } 33 \\
\text { C1: } 34 \\
\text { total: } 114\end{array}$ & $\begin{array}{l}\text { I1: } 1 \\
\text { I2: } 3 \\
\text { C1: } 0 \\
\text { total: } 4\end{array}$ & $\begin{array}{l}\text { I1: } 1 \\
\text { C1: } 2 \\
\text { total: } 3\end{array}$ \\
\hline $\begin{array}{l}\text { [\%] discontinuation } \\
\text { rate (I1/ } \mathrm{I} 2 \text { / C1 / to- } \\
\text { tal) }\end{array}$ & $\begin{array}{l}\text { I1: } 16 \\
\text { C1: } 18 \\
\text { total: } 17\end{array}$ & $\begin{array}{l}\text { I1: } 19 \\
\text { C1: } 22 \\
\text { total: } 20\end{array}$ & $\begin{array}{l}\text { I1: } 23.5 \\
\text { I2: } 17.3 \\
\text { C1: } 16.4 \\
\text { total: } 19\end{array}$ & $\begin{array}{l}\text { I1: } 7 \\
\text { I2: } 19 \\
\text { C1: } 0 \\
\text { total: } 9\end{array}$ & $\begin{array}{l}\text { I1: } 7 \\
\text { C1: } 13 \\
\text { total: } 10 \%\end{array}$ \\
\hline $\begin{array}{l}\text { Discontinuation } \\
\text { rate similar between } \\
\text { groups }\end{array}$ & $\mathrm{N}$ & Y & $\mathrm{N}$ & ? & $\mathrm{Y}$ \\
\hline
\end{tabular}

Rosiglitazone for type 2 diabetes mellitus (Review)

Copyright $\odot 2009$ The Cochrane Collaboration. Published by John Wiley \& Sons, Ltd. 


\begin{tabular}{|c|c|c|c|c|c|}
\hline $\begin{array}{l}\text { [\%] crossover be- } \\
\text { tween groups }\end{array}$ & ? & ? & ? & ? & ? \\
\hline $\begin{array}{l}\text { Differences }[\mathrm{n}] \text { cal- } \\
\text { culated to analysed } \\
\text { patients }\end{array}$ & $\mathrm{N}$ & NA & $?$ & NA & NA \\
\hline $\begin{array}{l}\text { Adjust- } \\
\text { ment for multiple } \\
\text { outcomes / repeated } \\
\text { measurements }\end{array}$ & $\mathrm{N}$ & $\mathrm{N}$ & $\mathrm{N}$ & $\mathrm{N}$ & $\mathrm{N}$ \\
\hline $\begin{array}{l}\text { Baseline characteris- } \\
\text { tics: Clinically rele- } \\
\text { vant differences }\end{array}$ & $\begin{array}{l}\mathrm{Y} \\
9 \% \text { more men in I1 } \\
\text { than C }\end{array}$ & $\mathrm{N}$ & $\begin{array}{l}\mathrm{N} \\
\text { rosiglitazone } 8 \mathrm{mg} \\
\text { less male partici- } \\
\text { pants) }\end{array}$ & $\begin{array}{l}\text { ? } \\
\text { HbA1c not } \\
\text { included in baseline } \\
\text { characteristics }\end{array}$ & $\begin{array}{l}\text { ? } \\
\text { HbAlc and resistin } \\
\text { not } \\
\text { included in baseline } \\
\text { characteristics }\end{array}$ \\
\hline $\begin{array}{l}\text { Treatment identical } \\
\text { (apart from inter- } \\
\text { vention) }\end{array}$ & $\mathrm{Y}$ & $\mathrm{Y}$ & $\mathrm{Y}$ & $\mathrm{Y}$ & $\mathrm{Y}$ \\
\hline $\begin{array}{l}\text { Compliance } \\
\text { measured }\end{array}$ & $\mathrm{N}$ & $\mathrm{N}$ & $\mathrm{N}$ & Y & $\mathrm{N}$ \\
\hline $\begin{array}{l}\text { Other important } \\
\text { covariates measured } \\
\text { (specify) }\end{array}$ & $\mathrm{N}$ & $\mathrm{N}$ & $\mathrm{N}$ & $\mathrm{N}$ & $\mathrm{N}$ \\
\hline $\begin{array}{l}\text { Co-morbidities } \\
\text { measured }\end{array}$ & $\mathrm{N}$ & $\mathrm{Y}$ & $\mathrm{N}$ & $\mathrm{N}$ & $\mathrm{N}$ \\
\hline $\begin{array}{l}\text { Co-medications } \\
\text { measured }\end{array}$ & $\mathrm{N}$ & $\mathrm{N}$ & $\mathrm{N}$ & $\mathrm{N}$ & $\mathrm{N}$ \\
\hline $\begin{array}{l}\text { Specific doubts } \\
\text { about study quality }\end{array}$ & $\mathrm{N}$ & $\mathrm{N}$ & $\mathrm{N}$ & $\mathrm{N}$ & $\mathrm{N}$ \\
\hline $\begin{array}{l}\text { Funding: commer- } \\
\text { cial }\end{array}$ & $\mathrm{Y}$ & $\mathrm{Y}$ & $\mathrm{Y}$ & $\mathrm{Y}$ & $\mathrm{N}$ \\
\hline $\begin{array}{l}\text { Funding: non-com- } \\
\text { mercial }\end{array}$ & $?$ & $?$ & $\mathrm{~N}$ & $\mathrm{Y}$ & $\mathrm{Y}$ \\
\hline $\begin{array}{l}\text { Publication status: } \\
\text { peer review journal }\end{array}$ & $\mathrm{N}$ & $\mathrm{Y}$ & Y & Y & $\mathrm{N}$ \\
\hline
\end{tabular}


(Continued)

\begin{tabular}{|c|c|c|c|c|c|}
\hline $\begin{array}{l}\text { Publication status: } \\
\text { journal supplement }\end{array}$ & $\mathrm{N}$ & $\mathrm{N}$ & $\mathrm{N}$ & $\mathrm{N}$ & $\mathrm{N}$ \\
\hline $\begin{array}{l}\text { Publication status: } \\
\text { abstract }\end{array}$ & $\mathrm{N}$ & $\mathrm{N}$ & $\mathrm{N}$ & $\mathrm{N}$ & $\mathrm{N}$ \\
\hline $\begin{array}{l}\text { Publication status: } \\
\text { other }\end{array}$ & $\mathrm{N}$ & $\mathrm{N}$ & $\mathrm{N}$ & $\mathrm{N}$ & $\mathrm{N}$ \\
\hline Notes & $\begin{array}{l}\text { commercial funding } \\
\text { not explicitly stated } \\
\text { but three of five au- } \\
\text { thors from pharma- } \\
\text { ceutical company }\end{array}$ & $\begin{array}{l}\text { no quantitative data } \\
\text { on adverse events }\end{array}$ & $\begin{array}{l}\text { sample size not re- } \\
\text { ported, LOCF pa- } \\
\text { rameter } \\
\text { unclear, baseline no } \\
\text { of participants } 587\end{array}$ & $\begin{array}{l}\text { patients } \\
\text { received written diet } \\
\text { instructions }\end{array}$ & $\begin{array}{l}\text { poor reporting on } \\
\text { quality criteria }\end{array}$ \\
\hline \multicolumn{6}{|c|}{$\begin{array}{l}\text { Footnotes } \\
\mathrm{Y}=\text { yes; } \mathrm{N}=\text { no; ? = unclear } \mathrm{I}=\text { intervention; } \mathrm{C}=\text { control; (baseline) = if numbers for certain features could ne be derived from the } \\
\text { text, numbers from baseline characteristics were used }\end{array}$} \\
\hline
\end{tabular}

Appendix 15. Risk of bias (III)

\begin{tabular}{|c|c|c|c|c|c|c|}
\hline Characteristic & Kahn 2006 & Кo 2006 & Lebovitz 2001 & Ovalle 2004 & Phillips 2001 & Raskin 2004 \\
\hline $\begin{array}{l}\text { Intervention } \\
1 \text { (I1) / interven- } \\
\text { tion } 2 \text { (I2) / con- } \\
\text { trol } 1 \text { (C1) }\end{array}$ & $\begin{array}{l}\text { I1: rosiglitazone } \\
\text { I2: metformin } \\
\text { C1: glyburide }\end{array}$ & $\begin{array}{l}\text { I1: rosiglitazone } \\
+\quad \text { (sulfonylurea } \\
+/- \text { metformin) } \\
\mathrm{C} 1 \text { : bedtime iso- } \\
\text { phane insulin + } \\
\text { (sulfonylurea }+/- \\
\text { metformin) }\end{array}$ & $\begin{array}{l}\text { I1: rosiglitazone } \\
2 \mathrm{mg} \\
\text { I2: rosiglitazone } \\
4 \mathrm{mg} \\
\mathrm{C} 1 \text { : placebo }\end{array}$ & $\begin{array}{l}\text { I1: rosiglitazone } \\
+ \text { glimepiride + } \\
\text { metformin }+ \\
\mathrm{C} 1 \text { : glimepiride } \\
+ \text { metformin + } \\
70 / 30 \text { mixed hu- } \\
\text { man insulin }\end{array}$ & $\begin{array}{l}\text { I1: rosiglitazone } \\
4 \quad \text { mg } \\
\text { od I2: rosiglita- } \\
\text { zone 2 mg bid I3: } \\
\text { rosiglitazone } 8 \\
\text { mg od I4: rosigli- } \\
\text { tazone } 4 \mathrm{mg} \text { bid } \\
\text { C1: placebo }\end{array}$ & $\begin{array}{l}\text { I1: rosiglitazone } \\
\text { I2: repaglinide } \\
\text { C1: rosiglitazone } \\
\text { + repaglinide }\end{array}$ \\
\hline $\begin{array}{l}\text { Randomised } \\
\text { controlled clini- } \\
\text { cal trial (RCT) }\end{array}$ & $\mathrm{Y}$ & $\mathrm{Y}$ & Y & Y & $\mathrm{Y}$ & $\mathrm{Y}$ \\
\hline $\begin{array}{l}\text { Non-inferiority / } \\
\text { equivalence trial }\end{array}$ & $\mathrm{N}$ & $\mathrm{N}$ & $\mathrm{N}$ & $\mathrm{N}$ & $\begin{array}{l}\text { Primary hypoth- } \\
\text { esis: superiority } \\
\text { of rosiglitazone } \\
\text { vs placebo; sec- } \\
\text { ondary hypoth- } \\
\text { esis: equivalence } \\
\text { of once daily vs }\end{array}$ & ? \\
\hline
\end{tabular}




\begin{tabular}{|c|c|c|c|c|c|c|}
\hline & & & & & $\begin{array}{l}\text { twice daily ad- } \\
\text { ministration of } \\
\text { rosiglitazones }\end{array}$ & \\
\hline $\begin{array}{l}\text { Controlled clini- } \\
\text { cal trial }\end{array}$ & $\mathrm{N}$ & $\mathrm{N}$ & $\mathrm{N}$ & $\mathrm{N}$ & $\mathrm{N}$ & $\mathrm{N}$ \\
\hline $\begin{array}{l}\text { Design: parallel } \\
\text { study }\end{array}$ & $\mathrm{Y}$ & $\mathrm{Y}$ & $\mathrm{Y}$ & $\mathrm{Y}$ & $\mathrm{Y}$ & $\mathrm{Y}$ \\
\hline $\begin{array}{l}\text { Design: } \\
\text { crossover study }\end{array}$ & $\mathrm{N}$ & $\mathrm{N}$ & $\mathrm{N}$ & $\mathrm{N}$ & $\mathrm{N}$ & $\mathrm{N}$ \\
\hline $\begin{array}{l}\text { Design: factorial } \\
\text { study }\end{array}$ & $\mathrm{N}$ & $\mathrm{N}$ & $\mathrm{N}$ & $\mathrm{N}$ & $\mathrm{N}$ & $\mathrm{N}$ \\
\hline $\begin{array}{l}\text { Crossover study: } \\
\text { wash-out phase }\end{array}$ & NA & NA & NA & NA & NA & NA \\
\hline $\begin{array}{l}\text { Crossover study: } \\
\text { carryover effect } \\
\text { tested }\end{array}$ & NA & NA & NA & NA & NA & NA \\
\hline $\begin{array}{l}\text { Crossover study: } \\
\text { period effect } \\
\text { tested }\end{array}$ & NA & NA & NA & NA & NA & NA \\
\hline $\begin{array}{l}\text { Method of ran- } \\
\text { domisation }\end{array}$ & $\begin{array}{l}\text { stratified accord- } \\
\text { ing to sex in } \\
\text { blocks of six }\end{array}$ & $?$ & $?$ & $?$ & $?$ & $?$ \\
\hline $\begin{array}{l}\text { Unit of randomi- } \\
\text { sation (individu- } \\
\text { als, cluster - spec- } \\
\text { ify) }\end{array}$ & individuals & individuals & individuals & individuals & individuals & individuals \\
\hline $\begin{array}{l}\text { Randomisa- } \\
\text { tion stratified for } \\
\text { centres }\end{array}$ & $\mathrm{N}$ & NA & ? & NA & ? & ? \\
\hline $\begin{array}{l}\text { Randomisation } \\
\text { ratio }\end{array}$ & $1: 1: 1$ & $1: 1$ & $1: 1$ & $1: 1$ & $1: 1: 1: 1: 1$ & $1: 1: 2$ \\
\hline $\begin{array}{l}\text { Concealment of } \\
\text { allocation }\end{array}$ & $\mathrm{Y}$ & ? & ? & ? & ? & ? \\
\hline $\begin{array}{l}\text { Stated blind- } \\
\text { ing (open; single, } \\
\text { double, triple } \\
\text { blind) }\end{array}$ & double-bind & open & double-blind & ? & double-blind & open \\
\hline
\end{tabular}




\begin{tabular}{|c|c|c|c|c|c|c|}
\hline $\begin{array}{l}\text { Actual blinding: } \\
\text { participant }\end{array}$ & $?$ & NA & $\mathrm{Y}$ & ? & ? & $\mathrm{N}$ \\
\hline $\begin{array}{l}\text { Actual blinding: } \\
\text { care- } \\
\text { giver / treatment } \\
\text { administrator }\end{array}$ & $?$ & NA & ? & ? & $?$ & $\mathrm{~N}$ \\
\hline $\begin{array}{l}\text { Actual blinding: } \\
\text { outcome assessor }\end{array}$ & ? & ? & ? & ? & ? & ? \\
\hline $\begin{array}{l}\text { Actual blinding: } \\
\text { others }\end{array}$ & $\mathrm{Y}$ & $?$ & $\mathrm{~N}$ & $\mathrm{~N}$ & $\mathrm{~N}$ & ? \\
\hline $\begin{array}{l}\text { Blinding } \\
\text { checked: partici- } \\
\text { pant }\end{array}$ & $\mathrm{N}$ & NA & $\mathrm{N}$ & $\mathrm{N}$ & $\mathrm{N}$ & NA \\
\hline $\begin{array}{l}\text { Blinding } \\
\text { checked: care- } \\
\text { giver / treatment } \\
\text { administrator }\end{array}$ & $\mathrm{N}$ & NA & $\mathrm{N}$ & $\mathrm{N}$ & $\mathrm{N}$ & NA \\
\hline $\begin{array}{l}\text { Primary } \\
\text { endpoint de- } \\
\text { fined (power cal- } \\
\text { culation) }\end{array}$ & $\mathrm{Y}$ & $\mathrm{Y}$ & $\mathrm{N}$ & $\mathrm{N}$ & $\mathrm{N}$ & $\mathrm{Y}$ \\
\hline $\begin{array}{l}\text { [n] of primary } \\
\text { endpoint(s) }\end{array}$ & 1 & 1 & 1 & 1 & 1 & 1 \\
\hline $\begin{array}{l}\text { [n] of secondary } \\
\text { endpoints }\end{array}$ & ? & $?$ & 10 & $6 ?$ & 8 & 7 \\
\hline $\begin{array}{l}\text { Total }[\mathrm{n}] \text { of end- } \\
\text { points }\end{array}$ & ? & 9 & 11 & 7 & 9 & 8 \\
\hline $\begin{array}{l}\text { Prior publication } \\
\text { of study design }\end{array}$ & $\mathrm{Y}$ & $\mathrm{N}$ & $\mathrm{N}$ & $\mathrm{N}$ & $\mathrm{N}$ & $\mathrm{N}$ \\
\hline $\begin{array}{l}\text { Out- } \\
\text { comes of prior/ } \\
\text { current publica- } \\
\text { tion identical }\end{array}$ & ? & NA & NA & NA & NA & NA \\
\hline $\begin{array}{l}\text { Power } \\
\text { calculation }\end{array}$ & $\mathrm{Y}$ & $\mathrm{Y}$ & $\mathrm{N}$ & $\mathrm{N}$ & $\mathrm{N}$ & $\mathrm{Y}$ \\
\hline
\end{tabular}




\begin{tabular}{|c|c|c|c|c|c|c|}
\hline $\begin{array}{l}\text { [n] participants } \\
\text { per group calcu- } \\
\text { lated }\end{array}$ & $\begin{array}{l}3600 \text { (initially) } \\
\text {; } 4182 \text { (March } \\
2002) ; \\
\text { further extension } \\
\text { of trial was de- } \\
\text { cided in Febru- } \\
\text { ary } 2004 \text { to com- } \\
\text { pensate } \\
\text { withdrawals }\end{array}$ & 50 & NA & NA & NA & total: 190 \\
\hline $\begin{array}{l}\text { Non-in- } \\
\text { feriority trial: in- } \\
\text { terval for equiva- } \\
\text { lence specified }\end{array}$ & NA & NA & NA & NA & Y & NA \\
\hline $\begin{array}{l}\text { Intention- } \\
\text { to-treat analysis } \\
\text { (ITT) }\end{array}$ & $\mathrm{Y}$ & $\mathrm{Y}$ & $\mathrm{Y}$ & $?$ & $\mathrm{Y}$ & Y \\
\hline $\begin{array}{l}\text { Per-protocol- } \\
\text { analysis }\end{array}$ & NA & $\mathrm{N}$ & ? & $?$ & $\mathrm{~N}$ & $?$ \\
\hline ITT defined & $\mathrm{N}$ & $\mathrm{N}$ & $\mathrm{Y}$ & NA & $\mathrm{Y}$ & Y \\
\hline $\begin{array}{l}\text { Miss- } \\
\text { ing data: last ob- } \\
\text { servation carried } \\
\text { forward (LOCF) }\end{array}$ & $\mathrm{N}$ & ? & $\mathrm{Y}$ & ? & Y & $\mathrm{N}$ \\
\hline $\begin{array}{l}\text { Missing data: } \\
\text { Other methods }\end{array}$ & $\mathrm{N}$ & $?$ & $\mathrm{~N}$ & $\mathrm{~N}$ & $\mathrm{~N}$ & Y \\
\hline LOCF defined & NA & ? & $\mathrm{Y}$ & NA & $\mathrm{N}$ & NA \\
\hline $\begin{array}{l}\text { Analysis strati- } \\
\text { fied for centres }\end{array}$ & $\mathrm{N}$ & NA & Y & NA & $\mathrm{N}$ & $\mathrm{N}$ \\
\hline $\begin{array}{l}{[\mathrm{n}] \text { of screened }} \\
\text { patients (I1 / I } 2 / \\
\mathrm{C} 1 / \text { total) }\end{array}$ & total: 6676 & $?$ & total: 623 & total: ? & total: 1503 & total: ? \\
\hline $\begin{array}{l}{[\mathrm{n}]} \\
\text { randomised par- } \\
\text { ticipants (I1/ I2 / } \\
\mathrm{C} 1 \text { / total) - pri- } \\
\text { mary endpoint }\end{array}$ & $\begin{array}{l}\text { I1: } 1456 \\
\text { I2: } 1454 \\
\text { C1: } 1441 \\
\text { total: } 4351\end{array}$ & $\begin{array}{l}\text { I1: } 56 \\
\text { C1: } 56 \\
\text { total: } 112\end{array}$ & $\begin{array}{l}\mathrm{I} 1: ? \\
\mathrm{I} 2: ? \\
\mathrm{C} 1: ? \\
\text { total: } 533\end{array}$ & $\begin{array}{l}\text { I1: } 9 \\
\text { C1: } 8 \\
\text { total: } 17\end{array}$ & $\begin{array}{l}\text { I1: ? } \\
\text { I2: ? } \\
\text { I3: ? } \\
\text { I4: ? } \\
\text { C1: ? } \\
\text { total: } 959\end{array}$ & $\begin{array}{l}\text { I1: } 62 \\
\text { I2: } 63 \\
\text { I3: } 127 \\
\text { total: } 252\end{array}$ \\
\hline
\end{tabular}




\begin{tabular}{|c|c|c|c|c|c|c|}
\hline $\begin{array}{l}\text { [n] of } \\
\text { participants fin- } \\
\text { ishing the study } \\
\text { (I1/ I2 / C1 / to- } \\
\text { tal) }\end{array}$ & $\begin{array}{l}\text { I1: } 917 \\
\text { I2: } 903 \\
\text { C1: } 807 \\
\text { total: } 2627\end{array}$ & $\begin{array}{l}\text { I1: } 50 \\
\text { C1: } 52 \\
\text { total: } 102\end{array}$ & $\begin{array}{l}\text { I1: ? } \\
\text { I2: ? } \\
\text { C1: ? } \\
\text { total: } 365\end{array}$ & $\begin{array}{l}\text { I1: ? } \\
\text { C1: ? } \\
\text { total: ? }\end{array}$ & $\begin{array}{l}\text { I1: ? } \\
\text { I2: ? } \\
\text { I3: ? } \\
\text { I4: ? } \\
\text { C1: ? } \\
\text { total: ? }\end{array}$ & $\begin{array}{l}\text { I1: } 37 \\
\text { I2: } 38 \\
\text { I3: } 106 \\
\text { total: } 181\end{array}$ \\
\hline $\begin{array}{l}\text { [n] of partici- } \\
\text { pants anal- } \\
\text { ysed (I1/ I2 / C1 } \\
\text { / total) - primary } \\
\text { endpoint }\end{array}$ & $\begin{array}{l}\text { I1: } 1393 \\
\text { I2: } 1397 \\
\text { C1: } 1337 \\
\text { total: } 4127\end{array}$ & $\begin{array}{l}\text { I1: ? } \\
\text { C1:? } \\
\text { total: ? }\end{array}$ & $\begin{array}{l}\text { I1: ? } \\
\text { I2: ? } \\
\text { C1: ? } \\
\text { total: } 472\end{array}$ & $\begin{array}{l}\text { I1: ? } \\
\text { C1: ? } \\
\text { total: ? }\end{array}$ & $\begin{array}{l}\text { I1: } 181 \\
\text { I2: } 186 \\
\text { I3: } 181 \\
\text { I4: } 187 \\
\text { C1: } 173 \\
\text { total: } 908\end{array}$ & $\begin{array}{l}\text { I1: } 55 \\
\text { I2: } 59 \\
\text { I3: } 126 \\
\text { total: } 240\end{array}$ \\
\hline $\begin{array}{l}\text { Description } \\
\text { of discontinuing } \\
\text { participants }\end{array}$ & $\mathrm{N}$ & $\mathrm{Y}$ & $\mathrm{N}$ & $\mathrm{N}$ & $\mathrm{N}$ & $\mathrm{N}$ \\
\hline $\begin{array}{l}\text { Drop-outs (rea- } \\
\text { sons explained) }\end{array}$ & $\mathrm{N}$ & $\begin{array}{l}\text { Y } \\
\text { partly }\end{array}$ & $\mathrm{N}$ & $\mathrm{N}$ & $\mathrm{N}$ & $Y$ \\
\hline $\begin{array}{l}\text { With- } \\
\text { drawals (reasons } \\
\text { explained) }\end{array}$ & Y & $\mathrm{N}$ & $\mathrm{N}$ & $\mathrm{N}$ & $Y$ & $\mathrm{~N}$ \\
\hline $\begin{array}{l}\text { Losses-to-fol- } \\
\text { low-up (reasons } \\
\text { explained) }\end{array}$ & $\mathrm{N}$ & $\mathrm{N}$ & $\mathrm{N}$ & $\mathrm{N}$ & $\mathrm{N}$ & $\mathrm{N}$ \\
\hline $\begin{array}{l}{[\mathrm{n}] \text { of partici- }} \\
\text { pants who dis- } \\
\text { continued (I1/ } \\
\mathrm{I} 2 / \mathrm{C} 1 / \text { total) }\end{array}$ & $\begin{array}{l}\text { I1: } 539 \\
\text { I2: } 551 \\
\text { C1: } 634 \\
\text { total: } 1724\end{array}$ & $\begin{array}{l}\text { I1: } 6 \\
\text { C1: } 2 \\
\text { total: } 8\end{array}$ & $\begin{array}{l}\text { I1: } 46 \\
\text { I2: } 45 \\
\text { C1: } 77 \\
\text { total: } 168\end{array}$ & $\begin{array}{l}\text { I1: ? } \\
\text { C1: ? } \\
\text { total: ? }\end{array}$ & $\begin{array}{l}\text { I1: ? } \\
\text { I2: ? } \\
\text { I3: ? } \\
\text { I4: ? } \\
\text { C1: ? } \\
\text { total: } 51\end{array}$ & $\begin{array}{l}\text { I1: } 25 \\
\text { I2: } 25 \\
\text { I3: } 21 \\
\text { total: } 71\end{array}$ \\
\hline $\begin{array}{l}\text { [\%] discontinua- } \\
\text { tion rate (I1/ I } 2 \text { / } \\
\mathrm{C} 1 / \text { total) }\end{array}$ & $\begin{array}{l}\text { I1: } 37 \\
\text { I2: } 38 \\
\text { C1:44 } \\
\text { total: } 44\end{array}$ & $\begin{array}{l}\text { I1: } 10.7 \\
\text { C1: } 3.6 \\
\text { total: } 7.1\end{array}$ & $\begin{array}{l}\text { I1: } 26 \\
\text { I2: } 25 \\
\text { C1: } 44 \\
\text { total: } 32\end{array}$ & $\begin{array}{l}\text { I1: ? } \\
\text { C1: ? } \\
\text { total: ? }\end{array}$ & $\begin{array}{l}\text { I1: ? } \\
\text { I2: ? } \\
\text { I3: ? } \\
\text { I4: ? } \\
\text { C1: ? } \\
\text { total: } 5 \%\end{array}$ & $\begin{array}{l}\text { I1: } 40.3 \\
\text { I2: } 39.7 \\
\text { I3: } 16.5 \\
\text { total: } 28.2\end{array}$ \\
\hline $\begin{array}{l}\text { Discontinu- } \\
\text { ation rate similar } \\
\text { between groups }\end{array}$ & ? & $\mathrm{N}$ & $\mathrm{N}$ & ? & $\begin{array}{l}\mathrm{N} \\
\text { "pa- } \\
\text { tients who with- } \\
\text { drew from treat- } \\
\text { ment were more }\end{array}$ & $\begin{array}{l}\mathrm{N} \\
\text { discontin- } \\
\text { uation rate lower } \\
\text { for repaglinide/ } \\
\text { rosigli- }\end{array}$ \\
\hline
\end{tabular}

Rosiglitazone for type 2 diabetes mellitus (Review) 


\begin{tabular}{|c|c|c|c|c|c|c|}
\hline & & & & & $\begin{array}{l}\text { poorly con- } \\
\text { trolled at base- } \\
\text { line" }\end{array}$ & $\begin{array}{l}\text { tazone combina- } \\
\text { tion therapy due } \\
\text { to } \\
\text { lack of efficiency } \\
\text { in the monother- } \\
\text { apy groups }\end{array}$ \\
\hline $\begin{array}{l}{[\%] \text { crossover be- }} \\
\text { tween groups }\end{array}$ & ? & ? & ? & ? & ? & ? \\
\hline $\begin{array}{l}\text { Differences } \\
\text { [n] calculated to } \\
\text { analysed patients }\end{array}$ & $\begin{array}{l}\text { additional } \\
\text { patients were re- } \\
\text { cruited during } \\
\text { the study }\end{array}$ & $\mathrm{N}$ & NA & NA & NA & $\mathrm{N}$ \\
\hline $\begin{array}{l}\text { Adjustment } \\
\text { for multiple out- } \\
\text { comes / repeated } \\
\text { measurements }\end{array}$ & $\mathrm{N}$ & ? & Y & $\mathrm{N}$ & $\mathrm{Y}$ & $\mathrm{N}$ \\
\hline $\begin{array}{l}\text { Baseline char- } \\
\text { acteristics: Clini- } \\
\text { cally relevant dif- } \\
\text { ferences }\end{array}$ & $\mathrm{Y}$ & $\begin{array}{l}\text { Y } \\
\text { gender, HbA1c, } \\
\text { metformin } \\
\text { dosage, antihy- } \\
\text { per- } \\
\text { tensive and lipid- } \\
\text { lowering agents }\end{array}$ & $\mathrm{N}$ & $\begin{array}{l}\text { ? } \\
\text { only few charac- } \\
\text { teristics re- } \\
\text { ported, numeri- } \\
\text { cal differences in } \\
\text { age }\end{array}$ & $\mathrm{N}$ & $\begin{array}{l}\text { previous } \\
\text { sulfonylurea / } \\
\text { metformin treat- } \\
\text { ment }\end{array}$ \\
\hline $\begin{array}{l}\text { Treatment iden- } \\
\text { tical (apart from } \\
\text { intervention) }\end{array}$ & $\mathrm{Y}$ & $\mathrm{Y}$ & $\mathrm{Y}$ & $\begin{array}{l}\text { there was no } \\
\text { titration period } \\
\text { in the rosiglita- } \\
\text { zone group }\end{array}$ & $\mathrm{Y}$ & Y \\
\hline $\begin{array}{l}\text { Compliance } \\
\text { measured }\end{array}$ & $\mathrm{N}$ & $\mathrm{N}$ & $\mathrm{N}$ & $\mathrm{N}$ & $\mathrm{N}$ & $\mathrm{N}$ \\
\hline $\begin{array}{l}\text { Other important } \\
\text { covariates mea- } \\
\text { sured (specify) }\end{array}$ & $\mathrm{N}$ & $\mathrm{N}$ & $\mathrm{N}$ & $\mathrm{N}$ & $\mathrm{N}$ & $\mathrm{N}$ \\
\hline $\begin{array}{l}\text { Co-morbidities } \\
\text { measured }\end{array}$ & $\mathrm{N}$ & $\mathrm{N}$ & $\mathrm{N}$ & $\mathrm{N}$ & $\mathrm{N}$ & $\mathrm{N}$ \\
\hline $\begin{array}{l}\text { Co-medications } \\
\text { measured }\end{array}$ & $\mathrm{N}$ & $\mathrm{Y}$ & $\mathrm{N}$ & $\mathrm{N}$ & $\mathrm{N}$ & $\mathrm{N}$ \\
\hline $\begin{array}{lr}\text { Specific } & \text { doubts } \\
\text { about } & \text { study } \\
\text { quality } & \end{array}$ & $\mathrm{N}$ & $\mathrm{N}$ & $\mathrm{N}$ & $\mathrm{Y}$ & $\mathrm{N}$ & $\mathrm{N}$ \\
\hline
\end{tabular}




\begin{tabular}{|c|c|c|c|c|c|c|}
\hline $\begin{array}{l}\text { Funding: } \\
\text { commercial }\end{array}$ & $\mathrm{Y}$ & $?$ & ? & $\mathrm{Y}$ & ? & $\mathrm{Y}$ \\
\hline $\begin{array}{l}\text { Funding: non- } \\
\text { commercial }\end{array}$ & ? & $?$ & ? & ? & ? & $?$ \\
\hline $\begin{array}{l}\text { Publication sta- } \\
\text { tus: peer review } \\
\text { journal }\end{array}$ & $\mathrm{Y}$ & $\mathrm{Y}$ & $\mathrm{Y}$ & $\mathrm{Y}$ & Y & $\mathrm{Y}$ \\
\hline $\begin{array}{l}\text { Publication sta- } \\
\text { tus: journal sup- } \\
\text { plement }\end{array}$ & $\mathrm{N}$ & $\mathrm{N}$ & $\mathrm{N}$ & $\mathrm{N}$ & $\mathrm{N}$ & $\mathrm{N}$ \\
\hline $\begin{array}{l}\text { Publication sta- } \\
\text { tus: abstract }\end{array}$ & $\mathrm{N}$ & $\mathrm{N}$ & $\mathrm{N}$ & $\mathrm{N}$ & $\mathrm{N}$ & $\mathrm{N}$ \\
\hline $\begin{array}{l}\text { Publication sta- } \\
\text { tus: other }\end{array}$ & $\mathrm{N}$ & $\mathrm{N}$ & $\mathrm{N}$ & $\mathrm{N}$ & $\mathrm{N}$ & $\mathrm{N}$ \\
\hline Notes & $\begin{array}{l}24 \text { weeks treat- } \\
\text { ment duration as } \\
\text { inclusion crite- } \\
\text { rion }\end{array}$ & .1. & $\begin{array}{l}\text { authors from } \\
\text { a pharmaceutical } \\
\text { company }\end{array}$ &.$/$ & $\begin{array}{l}\text { two authors hold } \\
\text { stocks in phar- } \\
\text { maceutical com- } \\
\text { panies }\end{array}$ & .1. \\
\hline \multicolumn{7}{|c|}{$\begin{array}{l}\text { Footnotes } \\
\mathrm{Y}=\text { yes; } \mathrm{N}=\text { no; ? = unclear } \mathrm{I}=\text { intervention; } \mathrm{C}=\text { control; }(\text { baseline })=\text { if numbers for certain features could ne be } \\
\text { derived from the text, numbers from baseline characteristics were used }\end{array}$} \\
\hline
\end{tabular}

\section{Appendix 16. Risk of bias (IV)}

\begin{tabular}{|c|c|c|c|c|}
\hline Characteristic & Rosenstock 2006b & Stocker 2007 & Sutton 2002 & Yang 2002 \\
\hline $\begin{array}{l}\text { Intervention } 1 \text { (I1) / in- } \\
\text { tervention } 2 \text { (I2) / con- } \\
\text { trol } 1 \text { (C1) }\end{array}$ & $\begin{array}{l}\text { I1: rosiglitazone + sul- } \\
\text { fonylurea + metformin } \\
\mathrm{C} 1 \text { : insulin } \\
\text { glargine + sulfonylurea + } \\
\text { metformin }\end{array}$ & $\begin{array}{l}\text { I1: rosiglitazone } \\
\mathrm{C} 1 \text { : metformin }\end{array}$ & $\begin{array}{l}\text { I1: rosiglitazone } \\
\mathrm{C} 1 \text { : glyburide }\end{array}$ & $\begin{array}{l}\text { I1: rosiglitazone } \\
\mathrm{C} 1 \text { : placebo }\end{array}$ \\
\hline $\begin{array}{l}\text { Randomised controlled } \\
\text { clinical trial (RCT) }\end{array}$ & $\mathrm{Y}$ & $\mathrm{Y}$ & $\mathrm{Y}$ & $\mathrm{Y}$ \\
\hline $\begin{array}{l}\text { Non-inferiority / equiv- } \\
\text { alence trial }\end{array}$ & ? & $\mathrm{N}$ & $\mathrm{Y}$ & $\mathrm{N}$ \\
\hline
\end{tabular}

Copyright $\odot 2009$ The Cochrane Collaboration. Published by John Wiley \& Sons, Ltd. 


\begin{tabular}{|c|c|c|c|c|}
\hline Controlled clinical trial & $\mathrm{N}$ & $\mathrm{N}$ & $\mathrm{N}$ & $\mathrm{N}$ \\
\hline Design: parallel & $\mathrm{Y}$ & $\mathrm{Y}$ & Y & Y \\
\hline Design: crossover study & $\mathrm{N}$ & $\mathrm{N}$ & $\mathrm{N}$ & $\mathrm{N}$ \\
\hline Design: factorial study & $\mathrm{N}$ & $\mathrm{N}$ & $\mathrm{N}$ & $\mathrm{N}$ \\
\hline $\begin{array}{l}\text { Crossover study: wash- } \\
\text { out phase }\end{array}$ & NA & NA & NA & NA \\
\hline $\begin{array}{l}\text { Crossover study: carry- } \\
\text { over effect tested }\end{array}$ & NA & NA & NA & NA \\
\hline $\begin{array}{l}\text { Crossover study: period } \\
\text { effect tested }\end{array}$ & NA & NA & NA & NA \\
\hline $\begin{array}{l}\text { Method of randomisa- } \\
\text { tion }\end{array}$ & ? & $\begin{array}{l}\text { random number genera- } \\
\text { tor, stratified by the use } \\
\text { of statins }\end{array}$ & ? & ? \\
\hline $\begin{array}{l}\text { Unit of randomisation } \\
\text { (individuals, cluster - } \\
\text { specify) }\end{array}$ & ? & individuals & ? & ? \\
\hline $\begin{array}{l}\text { Randomisation stratified } \\
\text { for centres }\end{array}$ & ? & NA & ? & ? \\
\hline Randomisation ratio & $1: 1$ & $1: 1$ & $1: 1$ & $1: 1$ \\
\hline $\begin{array}{l}\text { Concealment of alloca- } \\
\text { tion }\end{array}$ & $?$ & $\begin{array}{l}\text { "allocation-concealed } \\
\text { randomization" }\end{array}$ & $?$ & ? \\
\hline $\begin{array}{l}\text { Stated blind- } \\
\text { ing (open; single, dou- } \\
\text { ble, triple blind) }\end{array}$ & open & open & open & double-blind \\
\hline $\begin{array}{l}\text { Actual blinding: partici- } \\
\text { pant }\end{array}$ & $\mathrm{N}$ & NA & $\mathrm{N}$ & $\mathrm{Y}$ \\
\hline $\begin{array}{l}\text { Actual blinding: care- } \\
\text { giver / treatment admin- } \\
\text { istrator }\end{array}$ & $\mathrm{N}$ & NA & $\mathrm{N}$ & ? \\
\hline $\begin{array}{l}\text { Actual blinding: out- } \\
\text { come assessor }\end{array}$ & $?$ & $\mathrm{Y}$ & ? & ? \\
\hline Actual blinding: others & $\mathrm{N}$ & $\mathrm{N}$ & $\mathrm{N}$ & $\mathrm{N}$ \\
\hline
\end{tabular}




\begin{tabular}{|c|c|c|c|c|}
\hline $\begin{array}{l}\text { Blinding checked: par- } \\
\text { ticipant }\end{array}$ & NA & NA & NA & $\mathrm{N}$ \\
\hline $\begin{array}{l}\text { Blinding checked: care- } \\
\text { giver / treatment admin- } \\
\text { istrator }\end{array}$ & NA & NA & NA & $\mathrm{N}$ \\
\hline $\begin{array}{l}\text { Primary endpoint de- } \\
\text { fined (power calculation) }\end{array}$ & Y & Y & $\mathrm{Y}$ & $\mathrm{N}$ \\
\hline $\begin{array}{l}\text { [n] of primary endpoint } \\
\text { (s) }\end{array}$ & 1 & 1 & 1 & 1 \\
\hline $\begin{array}{l}\text { [n] of secondary end- } \\
\text { points }\end{array}$ & 7 & 2 & 10 & 10 \\
\hline Total [n] of endpoints & 8 & 8 & 11 & 11 \\
\hline $\begin{array}{l}\text { Prior publication of } \\
\text { study design }\end{array}$ & $\mathrm{N}$ & $\mathrm{N}$ & $\mathrm{N}$ & $\mathrm{N}$ \\
\hline $\begin{array}{l}\text { Outcomes of prior/cur- } \\
\text { rent publication identi- } \\
\text { cal }\end{array}$ & NA & NA & NA & NA \\
\hline Power calculation & $\mathrm{N}$ & $\mathrm{Y}$ & $\mathrm{Y}$ & $\mathrm{N}$ \\
\hline $\begin{array}{l}\text { [n] participants per } \\
\text { group calculated }\end{array}$ & NA & 40 & 60 & NA \\
\hline $\begin{array}{l}\text { Non-inferiority trial: in- } \\
\text { terval for equivalence } \\
\text { specified }\end{array}$ & NA & NA & Y & NA \\
\hline $\begin{array}{l}\text { Intention-to-treat analy- } \\
\text { sis (ITT) }\end{array}$ & $\mathrm{Y}$ & $\mathrm{N}$ & Y & ? \\
\hline Per-protocol-analysis & $\mathrm{N}$ & Y & Y & ? \\
\hline ITT defined & $\mathrm{Y}$ & NA & Y & $\mathrm{N}$ \\
\hline $\begin{array}{l}\text { Missing data: last ob- } \\
\text { servation carried forward } \\
\text { (LOCF) }\end{array}$ & $\mathrm{Y}$ & $\mathrm{N}$ & $\mathrm{Y}$ & $?$ \\
\hline $\begin{array}{l}\text { Missing data: Other } \\
\text { methods }\end{array}$ & $\mathrm{N}$ & $\mathrm{N}$ & $\mathrm{N}$ & $\mathrm{N}$ \\
\hline
\end{tabular}




\begin{tabular}{|c|c|c|c|c|}
\hline LOCF defined & $\mathrm{N}$ & NA & $\mathrm{N}$ & $\mathrm{N}$ \\
\hline $\begin{array}{l}\text { Analysis stratified for } \\
\text { centres }\end{array}$ & $\mathrm{Y}$ & NA & $\mathrm{N}$ & $?$ \\
\hline $\begin{array}{l}\text { [n] of screened patients } \\
\text { (I1 / I2/ C1/ total) }\end{array}$ & total: 341 & total: 120 & total: 351 & $?$ \\
\hline $\begin{array}{l}\text { [n] of randomised partic- } \\
\text { ipants (I1/ I } 2 / \mathrm{C} 1 / \text { to- } \\
\text { tal) - primary endpoint }\end{array}$ & $\begin{array}{l}\text { I1: ? } \\
\text { C1: ? } \\
\text { total: } 219\end{array}$ & $\begin{array}{l}\text { I1: } 45 \\
\text { C1: } 47 \\
\text { total: } 92\end{array}$ & $\begin{array}{l}\text { I1: } 104 \\
\text { C1: } 99 \\
\text { total: } 203\end{array}$ & $?$ \\
\hline $\begin{array}{l}\text { [n] of participants finish- } \\
\text { ing the study (I1/ I2 / C1 } \\
\text { / total) }\end{array}$ & $\begin{array}{l}\text { I1: ? } \\
\text { C1: ? } \\
\text { total: ? }\end{array}$ & $\begin{array}{l}\text { I1:? } \\
\text { C1:? } \\
\text { total: }\end{array}$ & $\begin{array}{l}\text { I1: ? } \\
\text { C1: ? } \\
\text { total: } 130\end{array}$ & $?$ \\
\hline $\begin{array}{l}\text { [n] of participants anal- } \\
\text { ysed (I1/ I } / \text { C } 1 \text { / total) } \\
\text { - primary endpoint }\end{array}$ & $\begin{array}{l}\text { I1: } 105 \\
\text { C1: } 112 \\
\text { total: } 216\end{array}$ & $\begin{array}{l}\text { I1: } 37 \\
\text { C1: } 38 \\
\text { total: } 75\end{array}$ & $\begin{array}{l}\text { I1: ? } \\
\text { C1: ? } \\
\text { total: ? }\end{array}$ & $\begin{array}{l}\text { I1: } 30 \\
\text { C1: } 34 \\
\text { total: } 64\end{array}$ \\
\hline $\begin{array}{l}\text { Description of discon- } \\
\text { tinuing participants }\end{array}$ & Y & Y & Y & $\mathrm{N}$ \\
\hline $\begin{array}{l}\text { Drop-outs (reasons ex- } \\
\text { plained) }\end{array}$ & $\mathrm{N}$ & Y & $\mathrm{N}$ & $\mathrm{N}$ \\
\hline $\begin{array}{l}\text { Withdrawals (reasons } \\
\text { explained) }\end{array}$ & $\mathrm{Y}$ & Y & Y & $\mathrm{N}$ \\
\hline $\begin{array}{l}\text { Losses-to-follow-up } \\
\text { (reasons explained) }\end{array}$ & $\mathrm{N}$ & NA & $\mathrm{N}$ & $\mathrm{N}$ \\
\hline $\begin{array}{l}\text { [n] of participants who } \\
\text { discontinued (I1/ I2 / C1 } \\
\text { / total) }\end{array}$ & $\begin{array}{l}\text { I1: } 11 \\
\text { C1: } 7 \\
\text { total: } 18\end{array}$ & $\begin{array}{l}\text { I1: } 8 \\
\text { C1: } 9 \\
\text { total: } 17 \\
\end{array}$ & $\begin{array}{l}\text { I1: } 40 \\
\text { C1: } 34 \\
\text { total: } 74 \\
\end{array}$ & $\begin{array}{l}\text { I1: ? } \\
\text { C1: ? } \\
\text { total: ? }\end{array}$ \\
\hline $\begin{array}{l}\text { [\%] discontinuation rate } \\
\text { (I1/ I2 / C1 / total) }\end{array}$ & $\begin{array}{l}\text { I1: ? } \\
\text { C1: ? } \\
\text { total: } 8\end{array}$ & $\begin{array}{l}\text { I1: } 17.8 \\
\text { C1: } 19.2 \\
\text { total: } 18.5\end{array}$ & $\begin{array}{l}\text { I1: } 38 \\
\text { C1: } 34 \\
\text { total: } 36\end{array}$ & $\begin{array}{l}\text { I1: ? } \\
\text { C1: ? } \\
\text { total: ? }\end{array}$ \\
\hline $\begin{array}{l}\text { Discontinuation rate } \\
\text { similar between groups }\end{array}$ & $\mathrm{Y}$ & $\mathrm{Y}$ & Y & $?$ \\
\hline $\begin{array}{l}{[\%] \text { crossover between }} \\
\text { groups }\end{array}$ & $?$ & $?$ & $?$ & $?$ \\
\hline $\begin{array}{l}\text { Differences [n] calcu- } \\
\text { lated to analysed patients }\end{array}$ & NA & $\mathrm{N}$ & $\mathrm{N}$ & NA \\
\hline
\end{tabular}




\begin{tabular}{|c|c|c|c|c|}
\hline $\begin{array}{l}\text { Adjustment for multi- } \\
\text { ple outcomes / repeated } \\
\text { measurements }\end{array}$ & $\mathrm{N}$ & $\mathrm{N}$ & $\mathrm{N}$ & $?$ \\
\hline $\begin{array}{l}\text { Baseline characteristics: } \\
\text { Clinically relevant differ- } \\
\text { ences }\end{array}$ & $\begin{array}{l}Y \\
\operatorname{sex}\end{array}$ & $\begin{array}{l}\text { Y } \\
\text { medications, sex }\end{array}$ & $\mathrm{N}$ & $\begin{array}{l}\mathrm{N} \\
\text { baseline val- } \\
\text { ues for adiponectin not } \\
\text { reported }\end{array}$ \\
\hline $\begin{array}{l}\text { Treatment } \\
\text { identical (apart from in- } \\
\text { tervention) }\end{array}$ & $\mathrm{Y}$ & $\mathrm{Y}$ & $\mathrm{Y}$ & Y \\
\hline Compliance measured & $\mathrm{N}$ & $\begin{array}{l}\text { Y } \\
\text { patient surveys, prescrip- } \\
\text { tion renewals, pill counts }\end{array}$ & $\mathrm{N}$ & $\mathrm{N}$ \\
\hline $\begin{array}{l}\text { Other important covari- } \\
\text { ates measured (specify) }\end{array}$ & $\mathrm{N}$ & $\mathrm{N}$ & $\mathrm{N}$ & $\mathrm{N}$ \\
\hline $\begin{array}{l}\text { Co-morbidities } \\
\text { measured }\end{array}$ & $\mathrm{N}$ & $\begin{array}{l}\text { Y } \\
\text { partly }\end{array}$ & $\mathrm{N}$ & $\mathrm{N}$ \\
\hline $\begin{array}{l}\text { Co-medications } \\
\text { measured }\end{array}$ & $\mathrm{N}$ & $\mathrm{Y}$ & $\mathrm{N}$ & $\mathrm{N}$ \\
\hline $\begin{array}{l}\text { Specific doubts about } \\
\text { study quality }\end{array}$ & $\mathrm{Y}$ & $\mathrm{N}$ & Y & $\mathrm{Y}$ \\
\hline Funding: commercial & $\mathrm{Y}$ & Y & $?$ & $\mathrm{Y}$ \\
\hline $\begin{array}{l}\text { Funding: non-commer- } \\
\text { cial }\end{array}$ & $\mathrm{N}$ & $\mathrm{N}$ & $\mathrm{N}$ & ? \\
\hline $\begin{array}{l}\text { Publication status: peer } \\
\text { review journal }\end{array}$ & Y & $\mathrm{Y}$ & $\mathrm{Y}$ & $\mathrm{Y}$ \\
\hline $\begin{array}{l}\text { Publication status: jour- } \\
\text { nal supplement }\end{array}$ & $\mathrm{N}$ & $\mathrm{N}$ & $\mathrm{N}$ & $\mathrm{N}$ \\
\hline $\begin{array}{l}\text { Publication status: ab- } \\
\text { stract }\end{array}$ & $\mathrm{N}$ & $\mathrm{N}$ & $\mathrm{N}$ & $\mathrm{N}$ \\
\hline Publication status: other & $\mathrm{N}$ & $\mathrm{N}$ & $\mathrm{N}$ & $\mathrm{N}$ \\
\hline Notes & $\begin{array}{l}\text { allocation concealment } \\
\text { unclear, blinding of out- } \\
\text { come assessor unclear, } \\
\text { open design }\end{array}$ & $\begin{array}{l}\text { open design, unclear } \\
\text { outcome assessment }\end{array}$ & $\begin{array}{l}\text { one author employed by } \\
\text { GlaxoSmithKline }\end{array}$ & $\begin{array}{l}\text { unclear how many pa- } \\
\text { tients were randomised, } \\
\text { how many discontin- }\end{array}$ \\
\hline
\end{tabular}




\section{F E E D B A C K}

\section{Dollow, July 2007}

\section{Summary}

The following query was made on 18 July 2007:

The Cochrane Collaboration has a reputation for robustness of analysis and integrity of data interpretation. Therefore, it was disappointing to read the conclusions made in the recent Cochrane Review written by Richter et al, titled, "Rosiglitazone for type 2 diabetes mellitus."

The authors drew conclusions regarding the impact of rosiglitazone on mortality and morbidity by reviewing a limited number of short term studies (18) primarily designed to assess glycaemic control. This analysis cannot provide a full picture of all the research conducted with rosiglitazone. The conclusions provide no new evidence about the role of rosiglitazone in clinical practice. In addition, the conclusions regarding cardiovascular safety disagree with the authors' own meta-analysis on myocardial infarction which could not confirm an increased risk.

The studies assessed in the review contained no stratification for baseline cardiovascular risk, leading to unavoidable imbalances between rosiglitazone and control groups. Most importantly the authors fail to include the interim findings of RECORD(1), a prospective longterm study primarily designed to evaluate the profile of rosiglitazone with respect to cardiovascular disease. The RECORD(1) data was available as an online publication some six weeks prior to the publication of this review. Its exclusion is surprising and adds question to the robustness of the authors' conclusions.

Questions about the safety of rosiglitazone should be answered by reviewing all relevant evidence, in particular long-term prospective trials. The conclusion regarding the cardiovascular data from $\operatorname{ADOPT}(2,3)$ are puzzling, given that in $\operatorname{ADOPT}(2,3)$ all major adverse cardiovascular events (MACE) were analysed and found to be rare in this population and comparable for all treatments - rosiglitazone, glibenclamide and metformin.. Additionally, no excess in mortality with rosiglitazone was seen overall. The significant benefits of rosiglitazone in maintaining the duration of glycaemic response in ADOPT(2) are unfortunately not given similar prominence.

The interim findings of RECORD(1), the only study specifically designed to look at cardiovascular outcomes with rosiglitazone, does not show evidence of a difference in cardiovascular death between rosiglitazone and control groups. Additionally, no significant differences for myocardial infarction between groups were seen.

The totality of the data - including long-term studies such as ADOPT(2) and RECORD(3) and a real-world epidemiological analysis of 33,000 patients(5) - show that rosiglitazone has a comparable ischaemic cardiovascular profile to the most commonly used oral antidiabetic medicines, metformin and sulphonylureas. 
With respect to the analysis of glycaemic efficacy, it is puzzling that the authors excluded a number of studies which are applicable to decisions made in clinical practice, such as Bailey et al(4) in which uptitration of metformin is compared with metformin and rosiglitazone. Additionally, whilst a significant decrease in the rate of hypoglycaemia associated with rosiglitazone is reported in the results section of the review, this is not referred to in the authors' conclusions. Instead, only oedema is mentioned, which is a well recognised side-effect of thiazolidenedione therapy.

The studies selected for use in a Cochrane systematic review should be appropriate to the purpose of the review. It is therefore difficult to understand how the limited range of studies selected from the much larger number of studies available, allow the authors to draw robust conclusions with respect to morbidity, mortality and health-outcomes for rosiglitazone. In addition, the conclusions drawn regarding ischaemic cardiovascular safety should be substantiated by the data analysed and not inferred from statistically insignificant odds ratios.

Finally we question the appropriateness of raising comment about the timing of data release to regulatory authorities and regulatory approval requirements in diabetes as part of a systematic review. GSK has actively shared data on rosiglitazone with regulatory agencies worldwide in a timely manner. The company carries out its clinical trials with the highest level of ethical conduct and is committed to patient safety.

References

1. Home PD et al N Engl J Med 2007; 357: 28-38

2. Kahn SE et al N Engl J Med 2006; 355: 2427-43.

3. Krall RL Lancet 2007; 369: 1995-1996

4. Bailey CJ et al Clin There 2005; 27:1548-1561

5. McAfee AT et al Pharmacoepidemiology Drug Saf; 2007 16: 711-725

Abbreviations

ADOPT - A Diabetes Outcome Progression Trial

RECORD - Rosiglitazone Evaluated for Cardiovascular Outcomes

\section{Reply}

The comments by Dr Dollow are answered in a point-by-point fashion:

The Cochrane Collaboration as well as the Metabolic and Endocrine Disorders Group adhere to high quality standards. It is unclear how Dr Dollow defines "integrity of data interpretation". As a matter of course, the discussion and conclusion sections are firmly based upon the data evaluated in our review.

The types of interventions we included had to have a minimum trial duration of 24 weeks. The point that a limited number of studies had a longer duration, for example more than one year, is due to the fact that neither the manufacturer nor the scientific community seems to be interested in the long-term benefit-risk ratio of rosiglitazone therapy, but cannot be attributed to the review itself. Furthermore, the bulk of studies investigated glycaemic control as primary efficacy endpoint and not patient-oriented parameters like mortality, morbidity and health-related quality of life which again has to be ascribed to the deficiencies of studies but not the systematic review. Our review so far provides the best overview of the risks and (with regard to relevant outcomes) missing benefits of rosiglitazone therapy and therefore is of great importance for clinical practice. We did not perform our own meta-analysis on myocardial infarction but tried to replicate the findings by Nissen et al using their data in the discussion section of our review (Nissen 2007). Cardiovascular disease and safety in their clinical meaning include more than myocardial infarction, for example increased risk of congestive heart failure following rosiglitazone therapy. Therefore, we stand by the conclusions as stated in the review.

The studies and publications we discovered and assessed in our review - with the exception of the ADOPT (A Diabetes Outcome Progression Trial) - did not investigate cardiovascular risk. That is one of the reasons why Nissen et al (Nissen 2007) had to search the manufacturer's as well as drug authorities web sites. The publication schedule of the Cochrane Library demands from Cochrane review groups to hand in their "module" (all new and updated protocols and reviews) around two months before the publication of the Cochrane Library. Therefore, the interim findings of the RECORD (Rosiglitazone Evaluated for Cardiac Outcomes and Regulation of Glycaemia in Diabetes) study could not be included in our review (Home 2007). Furthermore, these interim data do not provide assurance of the cardiovascular safety of rosiglitazone treatment in type 2 diabetes mellitus (see below).

We agree that questions about the safety of rosiglitazone should be answered by critical appraisal of especially well-performed longterm randomised controlled clinical trials. With regard to the cardiovascular data from the ADOPT trial Dr Dollow mentions a letter to the Lancet editor by Dr Krall, Chief Medical Officer of GlaxoSmithKline. It is of interest to note that this letter to the editor which refers to the Nissen et al publication was published in the Lancet and not the New England Journal of Medicine where the study originally was published. The new endpoint MACE (major adverse cardiovascular events, that is all cardiovascular deaths, myocardial infarction serious adverse events (fatal and non-fatal), and stroke serious adverse events (fatal and non-fatal)) was not part of the original

Rosiglitazone for type 2 diabetes mellitus (Review)

Copyright () 2009 The Cochrane Collaboration. Published by John Wiley \& Sons, Ltd. 
publication of the ADOPT trial, resulted from a post-hoc analysis by the manufacturer and "forgot" to mention congestive heart failure which was part of the outcomes contributing to the overall endpoint cardiovascular disease. Here, significant differences between glyburide (glibenclamide) and rosiglitazone were reported, indicating increased cardiovascular disease risk after rosiglitazone therapy, as mentioned in our review. The ADOPT trial was not powered to investigate mortality. The primary outcome time from randomisation to treatment failure as measured by elevated fasting plasma glucose levels was not part of our pre-specified outcomes but we agree with the accompanying New England Journal of Medicine editorial stating "the choice of time to failure based on a confirmed fasting glucose level of more than $180 \mathrm{mg}$ per deciliter as the primary outcome, rather than one based upon glycated hemoglobin levels, seems anachronistic" (Nathan 2006).

The unscheduled interim analysis from the RECORD trial should not be interpreted as evidence for cardiovascular safety of rosiglitazone therapy (Home 2007). We once again agree with the statements of the associated editorial in the New England Journal of Medicine (Nathan 2007):

"The primary end point of the RECORD trial consists of an aggregate of time to first hospitalization for a cardiovascular event or death from cardiovascular causes" ... "Unfortunately, this interim analysis, performed after a mean of 3.75 years (about $60 \%$ of the planned 6-year duration of the study) fails to provide exculpatory evidence" ... "RECORD extremely underpowered for the primary outcome" ... "the results of this underpowered interim analysis suggest a possible adverse effect of treatment with rosiglitazone on the primary outcome, rather than the benefit that was hypothesized ... considering the low power of the study and the trend for more adverse outcomes in the rosiglitazone-treated group, it is highly unlikely that the study will ever establish a cardiovascular benefit for rosiglitazone" ... "In the aggregate, however, these analyses support a concern regarding the safety of rosiglitazone" ... "It is reasonable to ask whether physicians should feel comfortable using a drug that might have an $8 \%$ excess risk of severe cardiovascular disease or death from cardiovascular causes" ... "Unless further studies provide convincing assurance that treatment with rosiglitazone does not increase the risk of cardiovascular disease, the largely circumstantial evidence of the meta-analyses and the nonsignificant trend in the current report from the RECORD trial must be taken seriously" ... "The jury may still be out with regard to the cardiotoxicity of rosiglitazone, but when it comes to patient safety, "first, do no harm "should outweigh any presumption of innocence."

As demonstrated above, the totality of data do not show that rosiglitazone has a comparable ischaemic cardiovascular profile to the most commonly used oral antidiabetic medicines. To claim a comparable ischaemic cardiovascular risk profile especially to metformin in obese type 2 diabetes patients appears careless: Contrary to rosiglitazone treatment metformin positively influences patient-oriented outcomes since the United Kingdom Prospective Diabetes Study (UKPDS) demonstrated that patients allocated metformin had significant reductions for any-diabetes related endpoint, diabetes-related death, stroke and all-cause mortality (UKPDS-34).

Dr Dollow claims that "authors excluded a number of studies which are applicable to decisions made in clinical practice, such as Bailey et $\mathrm{al}(4)$ in which uptitration of metformin is compared with metformin and rosiglitazone". In the 'criteria for considering studies for this review' we clearly exemplified under 'excluded interventions': "Combination therapies consisting of different compounds in the treatment arms (for example rosiglitazone plus metformin versus uptitration of metformin or rosiglitazone plus gliclazide versus gliclazide). Another Cochrane review will investigate rosiglitazone-metformin combination therapies including different treatment regimens of these compounds." We want to perform another Cochrane review on different combination partners because it does not appear to be adequate to compare interventions with different combination partners neglecting the complicated interplay of various agents. Furthermore, we did not report on a significant decrease in the rate of hypoglycaemia associated with rosiglitazone but stated "Seven of the 18 included studies showed data on hypoglycaemic episodes: Compared to active monotherapy control rosiglitazone treatment resulted in somewhat lower rates of hypoglycaemia, especially when compared to sulphonylureas. Severe hypoglycaemic events were rarely reported." Apart from that, serious adverse events were noted more often after rosiglitazone treatment as were higher median discontinuation rates compared to control therapy.

Our studies selected for this review were indeed appropriate to our objectives. To speak of a "limited range of studies selected from the much larger number of studies available" does not understand our strategy. We especially focused on patient-oriented parameters like mortality, morbidity, health-related quality of life and adequately reported on all available study results according to our in- and exclusion criteria. Unfortunately, the availability of sound studies is scarce due to the fact that concerning this matter only the ADOPT and the RECORD trial provide some hypotheses about the benefit-risk ratio of rosiglitazone therapy which does not appear to be positive (see above).

According to Krall (Krall 2007), GlaxoSmithKline performed similar meta-analyses in 2005 and 2006 and found similar results as Nissen et al (Nissen 2007). We are not aware that the public was adequately informed about these results, otherwise the meta-analysis by Nissen et al would not have aroused such a huge public interest. It is well know that glycosylated haemoglobin is a relatively poor surrogate for cardiovascular outcomes and these data urgently suggest that we need to change the regulatory pathway for drugs for the treatment of type 2 diabetes to make clinical outcomes, not surrogates, the primary endpoint (Rosen 2007). It would be prudent for one of the biggest pharmaceutical companies in the world being committed to patient care to engage in relevant clinical studies of patient-oriented outcomes from the very beginning on.

Rosiglitazone for type 2 diabetes mellitus (Review) 
References:

HOME 2007: Home PD, Pocock SJ, Beck-Nielsen H, Gomis R, Hanefeld M, et al. New England Journal of Medicine 2007;357:2838.

KRALL 2007: Krall RL. Cardiovascular safety of rosiglitazone. Lancet 2007; 369:1995-6.

NATHAN 2006: Nathan DM. Thizolidinediones for initial treatment of type 2 diabetes? New England Journal of Medicine 2006; 355:2477-80.

NATHAN 2007: Nathan DM. Rosiglitazone and cardiotoxicity - weighing the evidence. New England Journal of Medicine 2007;357: 64-6.

NISSEN 2007: Nissen SE, Wolski K. Effect of rosiglitazone on the risk of myocardial infarction and death from cardiovascular causes. New England Journal of Medicine 2007;356:2457-71.

ROSEN 2007: Rosen CJ. Rhe rosiglitazone story - lessons from an FDA Advisory Committee Meeting. New England Journal of Medicine 2007;357: Published at www.nejm.org August 8, 2007.

UKPDS-34: UK Prospective Diabetes Study Group. Effect of intensive blood-glucose control with metformin on complications in overweight patients with type 2 diabetes. Lancet 1998;352:854-65.

\section{Contributors}

Comments made by Dr Stuart Dollow, Vice President and UK Medical Director GlaxoSmithKline (stuart.c.dollow@GSK.com). Bernd Richter replied to the comments on behalf of the review authors for the review.

\section{WHAT'S NEW}

Last assessed as up-to-date: 29 April 2007.

\begin{tabular}{lll}
\hline Date & Event & Description \\
\hline 6 November 2008 & Amended & Converted to new review format. \\
\hline
\end{tabular}

\section{H I S T O R Y}

Protocol first published: Issue 2, 2006

Review first published: Issue 3, 2007

\begin{tabular}{lll}
\hline Date & Event & Description \\
\hline 18 July 2007 & Feedback has been incorporated & Comments and criticisms \\
\hline
\end{tabular}




\section{CONTRIBUTIONSOFAUTHORS}

BERND RICHTER: Protocol development, selection of studies, quality assessment, data extraction, data analysis, review development.

ELIZABETH BANDEIRA-ECHTLER: Protocol development, selection of studies, quality assessment, data extraction.

KARLA BERGERHOFF: Searching for trials, quality assessment, data extraction.

CHRISTINE CLAR: Protocol development, selection of studies, quality assessment, data extraction.

SUSANNE EBRAHIM: Protocol development, selection of studies, quality assessment, data extraction.

\section{DECLARATIONSOF INTEREST}

This review in part contributes to the ongoing critical appraisal of RCTs investigating the risk-benefit ratio of thiazolidinedione use by the German Institute for Quality and Efficiency in Health Care ('Institut fuer Qualitaet und Wirtschaftlichkeit im Gesundheitswesen - IQWiG).

\section{SOURCES OF SUPPORT}

\section{Internal sources}

- Heinrich-Heine University of Duesseldorf, Germany.

\section{External sources}

- No sources of support supplied

\section{DIFFERENCES BETWEEN PROTOCOLAND REVIEW}

The following changes to the published protocol with regards to 'types of intervention' were implemented:

The following comparisons were acceptable for evaluation:

- rosiglitazone versus placebo;

- rosiglitazone versus another oral antidiabetic medication (meglitinide analogues, metformin, pioglitazone, sulphonylureas);

- rosiglitazone in combination with an oral antidiabetic medication or insulin versus a combination of an oral antidiabetic medication or insulin (agents and treatment schemes had to be identical).

\section{Excluded interventions:}

Combination therapies consisting of different compounds in the treatment arms (for example rosiglitazone plus metformin versus uptitration of metformin or rosiglitazone plus gliclazide versus gliclazide). Another Cochrane review will investigate rosiglitazonemetformin combination therapies including different treatment regimens of these compounds. Furthermore, dipeptidyl peptidase- 4 (DPP-4) inhibitors for type 2 diabetes mellitus are excluded, since these are the topic of another Cochrane review (Richter 2007), as well as glucagon-like peptide analogues for type 2 diabetes mellitus (Cochrane review, Snaith 2007). 


\section{INDEX TERMS}

\section{Medical Subject Headings (MeSH)}

Diabetes Mellitus, Type 2 [*drug therapy]; Hypoglycemic Agents [adverse effects; *therapeutic use]; Randomized Controlled Trials as Topic; Thiazolidinediones [adverse effects; ${ }^{*}$ therapeutic use]

\section{MeSH check words}

Adult; Female; Humans; Male 